\title{
Recent Developments and Trends in Sheet Metal Forming
}

\author{
Tomasz Trzepieciński ${ }^{(D)}$
}

Department of Materials Forming and Processing, Rzeszow University of Technology, al. Powst. Warszawy 8, 35-959 Rzeszów, Poland; tomtrz@prz.edu.pl; Tel.: +48-17-743-2527

Received: 27 April 2020; Accepted: 9 June 2020; Published: 10 June 2020

\begin{abstract}
Sheet metal forming (SMF) is one of the most popular technologies for obtaining finished products in almost every sector of industrial production, especially in the aircraft, automotive, food and home appliance industries. Parallel to the development of new forming techniques, numerical and empirical approaches are being developed to improve existing and develop new methods of sheet metal forming. Many innovative numerical algorithms, experimental methods and theoretical contributions have recently been proposed for SMF by researchers and business research centers. These methods are mainly focused on the improvement of the formability of materials, production of complex-shaped parts with good surface quality, speeding up of the production cycle, reduction in the number of operations and the environmental performance of manufacturing. This study is intended to summarize recent development trends in both the numerical and experimental fields of conventional deep-drawing, spinning, flexible-die forming, electromagnetic forming and computer-controlled forming methods like incremental sheet forming. The review is limited to the considerable changes that have occurred in the SMF sector in the last decade, with special attention given to the 2015-2020 period. The progress observed in the last decade in the area of SMF mainly concerns the development nonconventional methods of forming difficult-to-form lightweight materials for automotive and aircraft applications. In evaluating the ecological convenience of SMF processes, the tribological aspects have also become the subject of great attention.
\end{abstract}

Keywords: electromagnetic forming; finite element method; flexible-die forming; flow-forming; incremental sheet forming; mechanical engineering; metal forming; numerical modeling; plastic working; sheet metal forming; solid granular medium forming; spinning; warm forming

\section{Introduction}

Sheet metal forming (SMF) techniques are widely used in many industries to produce final-shaped components from a workpiece. In an SMF process, a thin piece of metal sheet is stretched into a desired shape by a tool without wrinkling or excessive thinning. In the past decade, methods for forming high-strength material with low plasticity and difficult-to-form metals have been developed for cold, warm and hot forming conditions [1,2].

The mechanical properties of the metallic sheet are an important factor and inadequate consideration of this factor in the design of SMF manufacturing processes causes buckling, excessive thinning, tearing and wrinkling of the components. Other factors that affect the final shape of the components include the geometry of the tool (i.e., punch-to-die clearance, die and punch radii) [3,4], friction conditions (i.e., dry or lubricated contact, lubricant type, contact pressure) [5-9], technological parameters (i.e., forming temperature, forming speed,) [10-12], properties of tool material [13-15] and initial surface topography [16-18]. The existence of friction forces at the workpiece-tool interface determines the nonuniformity of the sheet deformation and quality of the surface of the final part [19]. Considering the prediction of formability, numerical models are widely employed in both industry and 
research development. Ma and Sugitomo [20] developed a LS-DYNA customized friction subroutine and verified it experimentally. This considered the change of COF with sliding distance, sliding velocity, contact pressure, plastic strain, frictional work and temperature. Ma and Sugimoto [21] suggest that lubrication phenomena can be positively changed during pulse-servo motion. Simulation results using a nonlinear friction model for a pulse servo motion agreed very well with experimental measurement for evaluating forming cracks. A comprehensive review of developments and trends in friction testing for conventional sheet metal forming and incremental sheet forming has been discussed by Trzepiecinski and Lemu [22].

In recent years there has been a dynamic development of two- and three-dimensional numerical modeling of the sheet metal forming (SMF) processes using the finite element method (FEM) [23-25], boundary element method (BEM) [26], finite difference method (FDM) [27], computational fluid dynamics (CFD) [28,29], finite volume method (FVM) [30], neural networks [24], multi grid and mesh free methods [23], crystal plasticity finite element (CPFEM) [2,31,32], discrete element method (DEM) [33,34], extended finite element (XFEM) [35], an arbitrary Lagrangian-Eulerian (ALE) [36,37], cellular automata (CA) [38,39] and fast Fourier transformation (FFT) [40].

During the last decade the above mentioned approaches to the numerical modeling of sheet metal forming operations have been primarily been focused on the development of optimization procedures that could be applied to complex processes, on improving the description of material behavior in both multiphysics models [38-41] and a multiscale modeling framework based on the microscale crystal plasticity theory and on a macroscale element-free methodology for computational simulation of polycrystalline metals [42,43].

Ablat and Quattawi [44] discussed different methods of solution in the simulation of SMF. According to Makinouchi et al. [45] numerical formulations of SMF can be classified into three main categories, which are, static explicit, static implicit and dynamic explicit. Numerical modeling of the forming of new metallic materials, i.e., multiphase steels, requires full-field models [29]. Full-field homogenization refers to the spatially resolved solution of a representative volume element (RVE) by means of FEM [46,47] or spectral methods using a fast Fourier transform approach (FFT) [37]. In this case a microstructure morphology as well as phenomena occurring during forming are precisely simulated at various length scales [2].

To overcome the limitations of FEM in modeling microstructures [48,49], numerical simulation techniques have been developed for incorporating material behavior on different length scales. Computational materials science (CMS) with the emerging concept of digital materials representation (DMR) [50] has been intensively investigated during the last decade. This concept provide a digital model of the microstructure where all important features are represented explicitly and can offer a support to the description of a material's behavior during the forming of new products with special in-use properties [2,51]. In $2020 \mathrm{Han}$ et al. [52] proposed a microstructure-based multiscale modeling of large strain plastic deformation by coupling a full-field crystal plasticity-spectral solver with an implicit finite element solver. The model which was developed takes both dislocation density and phenomenological hardening law into account and is suitable for modeling materials with complex microstructural characteristics (e.g., grain morphology, multiple phases and textures).

During the last decade, the coupling of individual computational methods to provide both multiscale and multiphysics responses has proved to have enormous predictive capabilities. In order to analyze the sheet metal forming processes, combinations of a range of CPFEM and XFEM numerical techniques have been applied. CPFEM can explicitly consider lattice rotation, and thus capture the geometric softening effect which is the main mechanism of shear band formation in strain hardening metals under quasi-static loading [2,28]. The CPFEM formulations for polycrystalline materials could be realized in macro-, meso- and microscales, classified by the size represented by each element in the FEM. The XFEM technique is an inexpensive, powerful, secure and time-saving numerical formulation for the analysis of crack problems [32]. 
The issues related to the increased predictive capability of numerical simulations with simultaneous reduction in computational time have also gained much attention in the area of the modeling of sheet metal forming $[53,54]$. To overcome the limitations of classical mesh numerical techniques which require significant computational effort in remeshing steps, meshless or mesh-free methods have been developed. These methods require only nodal data without explicit connectivity between nodes $[21,55]$. In meshless methods, i.e., SPH, the interpolation accuracy is not significantly affected by the nodal distribution, so interpolation is free of the mesh requirement [56,57].

Numerical modelling is used to predict material flow [58], stress distribution [59,60], deformation $[58,61]$, temperature distribution [62,63], prediction of phase transformations [64,65], springback [66,67], sheet thickness change [68] as well as for determining forming forces [69,70], locations of potential wrinkling and cracking [66,71] and for predicting forming limit diagrams (FLDs) [72,73]. Numerical simulations coupled with advanced 3D-adaptive remeshing procedures and fully coupled damage constitutive equations play an important role in the control and optimization of material flow in SMF. Digital material representation concepts are also created to evaluate the influence of local microstructural features in the form of twins on material behavior [74]. Numerical simulation has become an indispensable tool for the prediction of crack occurrence during sheet forming and fracture behavior under strong impact loading when designing and fabricating automotive parts made of high-strength steels. In the past decade, various approaches to the prediction of the initiation and propagation of forming cracks have been presented and several fracture criteria have been proposed. Ma et al. [75] employed the plastic strain criterion depending on the triaxial nature of stress in the prediction of fracture in stamping parts using the simple tensile test. They also applied the digital image grid method (DIGM) to measure the strain localization behavior and local strain distribution. Based on DIGM, a new method for the identification of the ductile damage limit of steel sheets was proposed with the aid of the historical path of nonlinear local strain and local fracture strain that had been measured. The commonly used Cockroft damage criterion, in which the plastic strain and the maximum principal stress are integrated, is an effective method to predict fracture under various loading conditions [76]. In a later study, Ma et al. [77] combined the measured transient displacement field with the FEM and a measurement-based FEM (M-FEM) was developed for the computation of the distribution of the local stress and strains, and the accumulation of ductile damage in a tensile test piece.

High-strength steel is increasingly finding uses in automotive body parts, whose properties tend to increase shape deviations (springback) after the forming stage. Many countermeasures are commonly used, including the use of lock beads [78,79], die-shape compensation $[80,81]$ and the improvement of forming process design $[82,83]$. The numerical prediction of elastic deformations of metallic sheets is also vitally important. To meet their needs, the accuracy of springback prediction has been significantly improved over the last decade [84], and the sheet metal forming simulation system JSTAMP has been providing advanced capabilities [85-87]. The compensation capabilities in JSTAMP are powerful methods to compensate the stamping tools, and the compensated CAD surfaces of the stamping tools can be directly exported from JSTAMP to CAM for machining [87]. In a similar manner to the prediction of springback, surface defects must be also controlled in the stamping process in order to make high quality outer panels of auto bodies. Measuring methods based on stoning and light reflection and the three-point curvature method are commonly used to detect surface defects. The cheapest and most convenient method is the stoning method supported by the JSTAMP system which does without any expensive measuring devices except a stone block [88].

This article summarizes recent trends in both the numerical and experimental contributions of SMF developed in the last decade. The main techniques of SMF, i.e., conventional deep-drawing, spinning, shear forming, flow forming, electromagnetic forming (EMF), flexible-die forming, electro-hydraulic forming, shear forming, solid granular medium forming, and incremental sheet forming are addressed. 


\section{Methods}

This systematic review of the latest progress in the area of SMF was prepared following the PRISMA guidelines [89]. To meet the PRISMA checklist, the following assumptions were made:

- To fulfil the goal of this study, international databases were explored including (in alphabetical order: Bielefield Academic Search Engine, DOAJ Directory of Open Access Journals, eLibrary;ru, GoogleScholar, INGENTA, ScienceDirect, Springer, Web of Science, WorldCat, WorldWideScience;

- Year restrictions: the databases were explored for the period of the past decade with special attention to the 2015-2020 period;

- The English language is selected as the main source of review;

- Duplicated articles found in different databases were not considered;

- Papers which did not fit the goal of this study were excluded;

- No search engines were used; papers were reviewed manually;

- References available in the articles found were also considered.

\section{Conventional Sheet Metal Forming}

\subsection{Sheet Microforming}

Micromanufacturing technologies have been developed to meet an increased tendency to product miniaturization, and among these, microforming is a promising method of producing microparts. Engel and Eckstein [90] defined microforming as the fabrication of metallic microparts or structures with at least two dimensions in the submillimeter range for microsystems or microelectromechanical systems (MEMS). Due to the size effect, there are many issues including deformation behavior (anisotropy, flow stress, limit strains), tools, machines, deformation defects in micro forming and damage accumulation which could be barriers to the production of micro- and mesoparts (Figure 1) [91,92]. In the case of material properties, grain size is the most important parameter which limits part geometry and limits strains in microforming. In the past decade many investigations have been devoted to studying the size effect on the fracture mechanism [93], plastic deformation [94-97], formability of material in microforming [98], Hall-Petch effect [99], elastic recovery [100,101], fracture behavior [102,103], surface roughness $[104,105]$ and the hardness of parts $[105,106]$. The sheet microforming process is recognized as one of the most efficient processes for producing microparts from sheet metals.

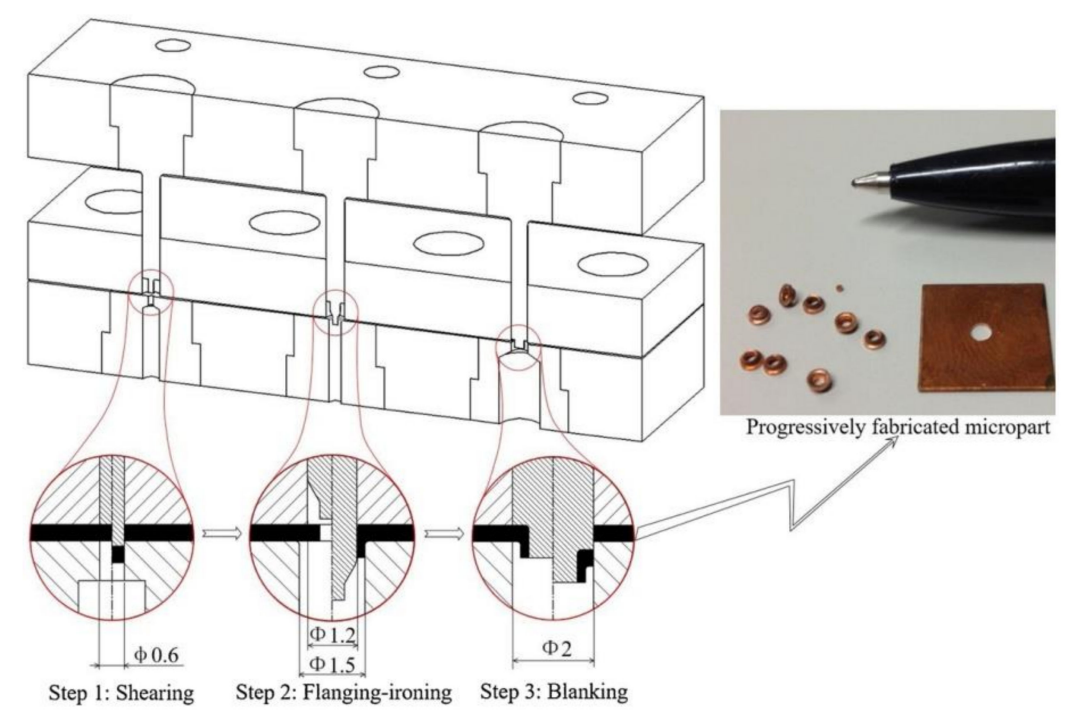

Figure 1. An example of the experimental die layout and finished microparts (reproduced with permission from [107]; copyright (C) 2018 Elsevier B.V.). 
Parallel to conventional sheet microforming, micro-hydromechanical deep drawing [108] is widely investigated. The hydroforming pressure and rate of applying pressure have a significant effect on formability [109]. The increase of hydroforming pressure and stamping force yields a better surface finish. In rubber pad micro forming (RPM), the rubber pad is compressed and then deformed to push the blank into the die cavity. In this method only a single rigid tool is needed, and it avoids the punch cavity misalignment problem. Several researchers employed the RPM to study the effect of tool geometry, interfacial friction and hardness on the deformation process of embossing microchannels $[107,110]$. The dimensional accuracy of RPM parts is difficult to control due to the large elastic deformation of the pressure carrying medium, viz., the rubber [107]. Compared to conventional SMF processes involving rigid dies, microsheet formation by the rubber-pad forming process has many advantages [111]: (i) the process only uses one rigid die, (ii) there is no problem in precise orientation of the soft punch in relation to the rigid die, (iii) the cost and processing time can be greatly reduced compared to conventional SMF. Many researchers $[110,112,113]$ have successfully employed rubber-pad-forming (Figure 2) to fabricate high-performance proton exchange membrane fuel cells.

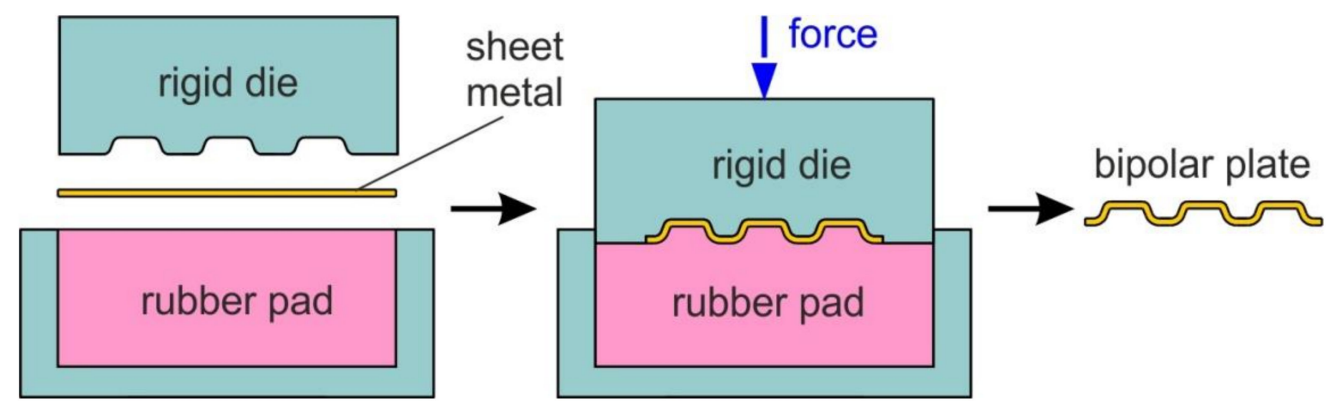

Figure 2. Diagram of the rubber-pad-forming process.

Laser shock microforming is an alternative method of microforming and is conceived as a non-thermal method of laser forming for thin metal sheets using the shock wave induced by laser irradiation (Figure 3a) [114-116]. High velocity forming processes have many potential advantages including higher resistance to wrinkling and higher forming limits. The pressure distribution is a crucial issue in high velocity forming processes. When the forming pressure is not uniform, puckers will be generated by uneven material flow velocity [117]. The plastic deformation induced by the shock wave and the direct plasma pressure applied on the material generate a residual stress distribution in the material finally leading to its bending (Figure $3 b$ ). The final bending of the specimens can be controlled over a relatively wide range by a stable quasi-proportional relationship to the number of pulses applied, and water confinement for the plasma leads to the ability to increase the pressure around 10 times and the final deformation has a significant increase.

In the case of thin metal sheets, the uneven pressure will promote the onset of localized necking instability which will lead to fracture. Therefore, Shen et al. [118] proposed a mechanism for a rubber-induced smoothing effect on the confined laser shock in order to smooth the laser shock wave (Figure 4). It has been suggested that the smoothing effect is mainly due to the radial expansion of the plasma cloud on the rubber surface. 


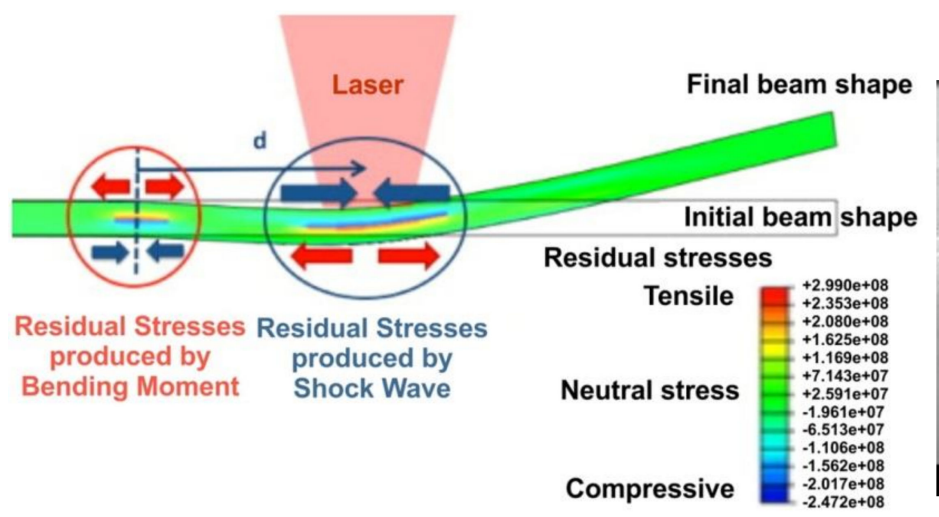

(a)

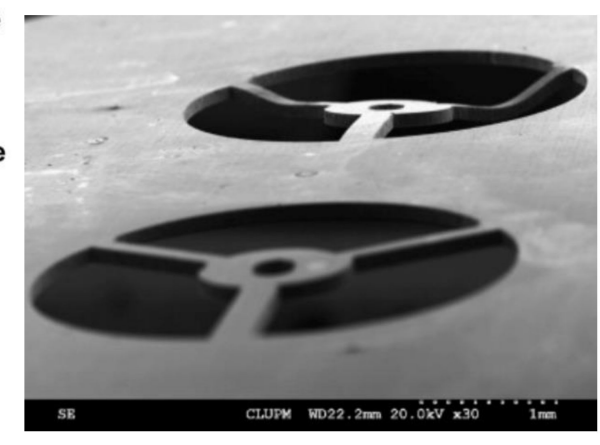

(b)

Figure 3. (a) schematic diagram of deformation and stresses for a single-pinned strip and (b) scanning electron microscopy micrograph of a three-bridge actuator (reproduced with permission from [114]; copyright (C) 2011 Elsevier B.V.).

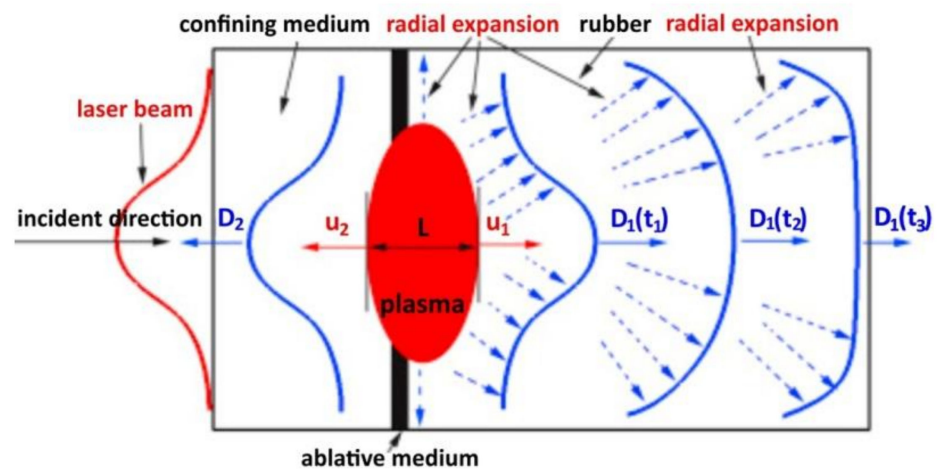

Figure 4. Mechanism of rubber-induced smoothing effect (reproduced with permission from [118]; copyright (C) 2015 Elsevier B.V.).

New methods and processes for a mastered mass production of micro parts which are smaller than $1 \mathrm{~mm}$ have been described in the SPB 747 report of the Collaborative Research Center of the University of Bremen (Germany) on "Micro Cold Forming". This report is focused on the description of micro forming processes [119], process design [120], tooling [121], and quality control and the characterization [122] of high-precision micro parts.

\subsection{Warm/Hot Forming}

Warm forming is usually carried out at $0.35 T_{m}<T<0.55 T_{m}$, where $T_{m}$ is the melting temperature of the metal [123]. It is important to distinguish warm forming from hot forming. Hot forming is carried out at temperatures $T>0.55 T_{m}$. In hot forming the temperatures exceed the melting temperature of the material and this allows simultaneous recrystallization, which controls the refinement of grain size [124,125]. In this way warm forming improves the formability of a material by lowering the yield stress. In comparison to hot forming processes, warm forming requires higher forces for deformation because of the greater material flow stress [126-128].

The quenching operation in the hot stamping process has a significant influence on the phase transition and mechanical properties of the hot-stamping steel. A proper quenching technique is quite important to control the microstructure and properties of an ultra-high-strength hot-stamping steel [129]. Kayan and Kaftanoglu [130] proposed non-isothermal deep drawing which is applied to DP600 HSLA and IF steels in elevated temperature conditions. They found that the process increases the LDR and there is no significant change in the microstructure of the material due to warm forming. 
The application strategy that was developed can solve the problems encountered in applications at ambient conditions, such as dimensional instabilities due to springback and high residual stresses.

The formability of the material increases with an increase in the forming temperature and is also affected by the microstructure, which changes according to the temperature at which the material is deformed [131-133]. In the case of austenitic stainless steel, martensite formation is not only affected by temperature, but also influenced by the rate at which the material is deformed [125].

Warm forming is used for stainless steels [134], aluminum alloys [135], magnesium alloys [136] and dual-phase steels [137] to reduce springback and the forming forces [42]. The springback phenomenon is one of the main problems associated with the assurance of the desired shape and dimensional accuracy of the formed part after its removal from the stamping tool [138,139].

Compared with conventional SMF processes, forming carried out at an elevated temperature requires an initial increase of the blank temperature before the forming stage [140-142]. Two main strategies are used for the heating process. The whole blank is heated in the furnace to receive a uniform temperature in the whole blank or the workpiece is heated locally using different techniques [143]. The whole blank heating strategy can be accomplished externally in an oven or internally through conduction from a heated tool. The strategy commonly used in industry is uniform heating of the blank [144]. The effect of the heating method and temperature on the formability of metals was widely studied by many authors $[125,145,146]$.

A robotized assembly stand with induction heater was proposed to minimize the loss of heat into the environment at the stage of transferring the sheet from the heater to the stamping die (Figure 5) when warm forming a 17-4PH stainless steel turbine engine strut [123] (Figure 6a). The effect of overheating of the blank on the dimensional deviation of the drawpiece due to the transfer of the blank from the heater to the stamping die using an industrial robot is also considered. The temperature of the tools during the experiments was stabilized by cooling channels located in the stamping die (Figure 6b).

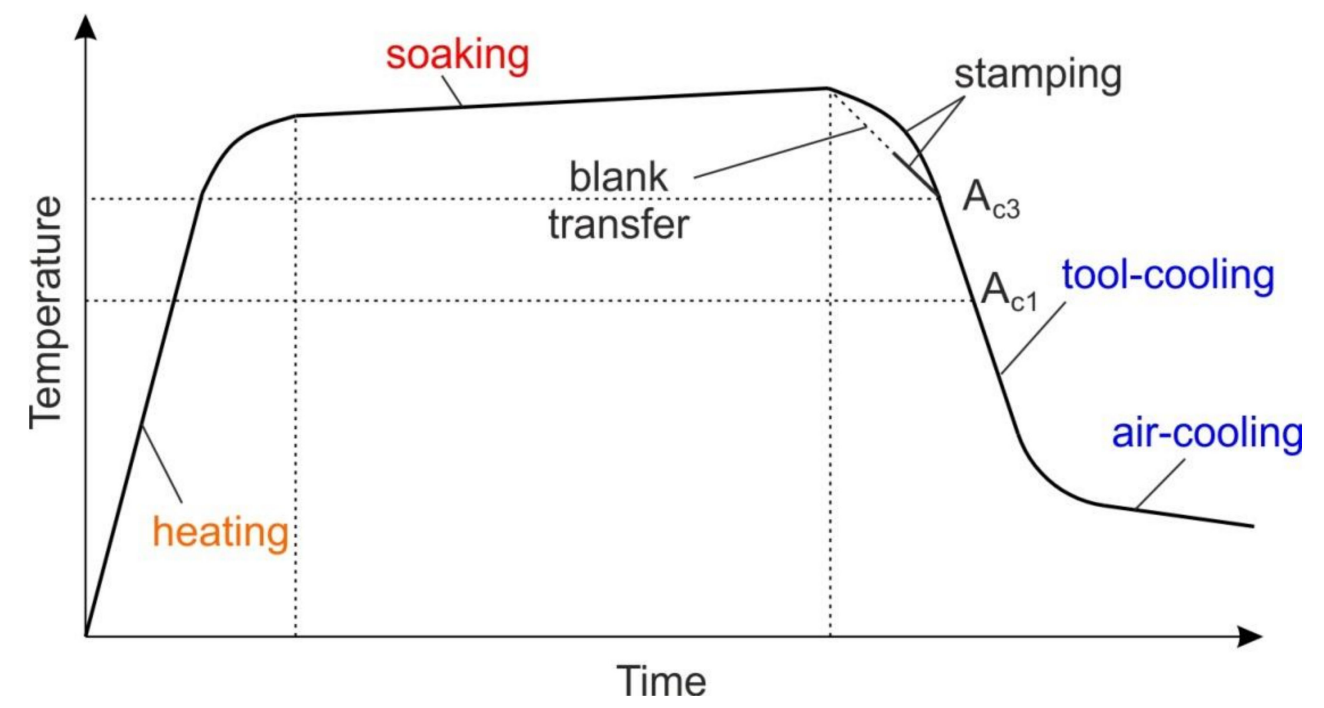

Figure 5. Temperature change versus time in the warm stamping process.

During forming of a sheet heated to a temperature up to $600{ }^{\circ} \mathrm{C}$, a very large springback of the drawpiece material is observed. The forming temperature that guaranteed receiving the component with the required shape deviations appropriate to the forming temperature was about $680{ }^{\circ} \mathrm{C}$. This led, however, to the blank overheating and reaching a temperature of $820^{\circ} \mathrm{C}$. 


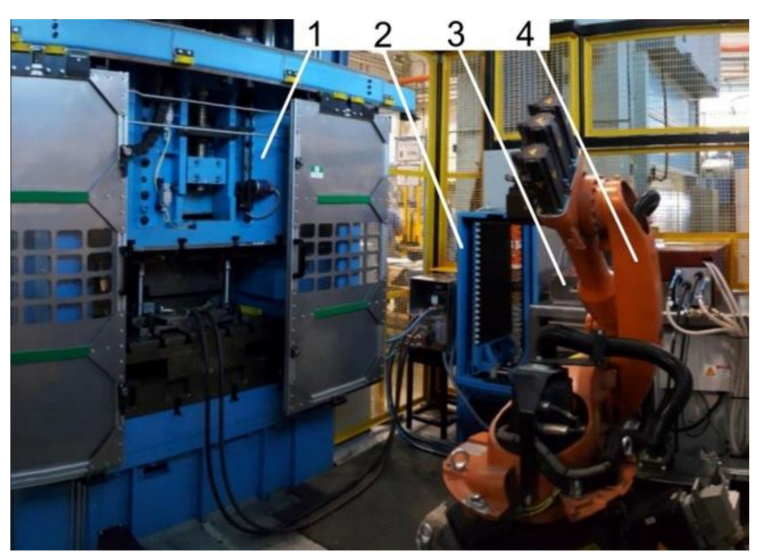

(a)

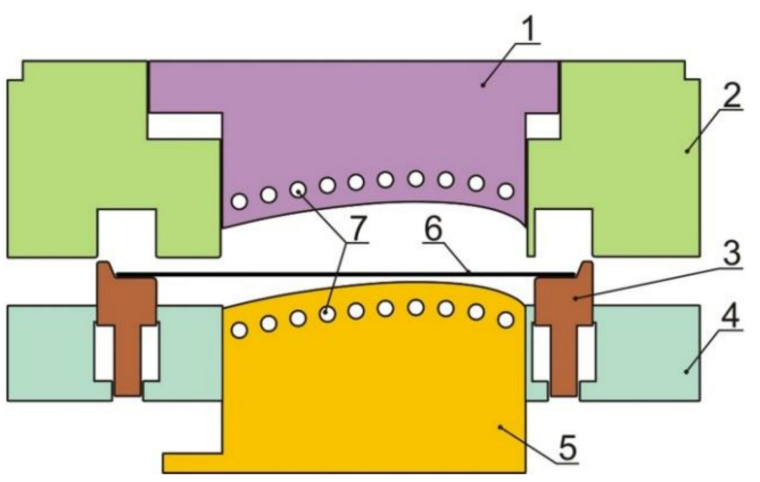

(b)

Figure 6. (a) Industrial stand for warm SMF (1-press, 2-workpiece store, 3-induction heater, 4-robot arm) and (b) scheme of stamping die (1-die, 2-upper blank holder, 3-positioner/knock-out, 4-lower blank holder, 5-punch, 6-workpiece, 7-cooling channels) (reproduced with permission from [123]; copyright (C) 2018 Elsevier B.V.).

In order to increase the collision-safe performance and reduce weight, the use of ultra-high-strength steel (UHSS), multiphase transformation-induced plasticity [TRIP] steels and advanced high-strength steels (AHSS) has gained attention in the automobile industry $[147,148]$. Besides the AHSSs, dual-phase (DP) steels consisting of martensite and ferrite phases are characterized by a proper balance between formability and high strength, and thus there is a growing interest in this type of sheet metal in the automotive industry. Due to the high-strength properties of DP steels, forming at elevated temperatures is required [149]. The thermal-mechanical behavior of DP590 sheet metal examined with uniaxial tensile tests as well as biaxial tensile tests at elevated warm-forming temperatures $\left(20-190{ }^{\circ} \mathrm{C}\right) \mathrm{can}$ be found in [149]. A dynamic strain aging effect was observed via thermal-uniaxial tensile tests and the Swift hardening model with temperature-dependent parameters. Inflow resistance of the flange surface of the UHSS parts increased due to rapid cooling caused by contact with the tool, and as a result formability in hot stamping deteriorated in comparison with cold forming conditions when the forming speed was low [150].

Warm forming at temperatures from $200^{\circ} \mathrm{C}$ to $600^{\circ} \mathrm{C}$ has several advantages compared with cold forming at room temperature: better shape accuracy, better stretch flange formability and lower press load. The results of the stretch formability of uncoated high-strength steel sheets and galvannealed HSS sheets in warm forming assessed by spherical stretch forming tests at temperatures from room temperature to $600{ }^{\circ} \mathrm{C}$ can be found in [151]. It was concluded that the COF has a significant influence on formability in the low temperature range of $200-400{ }^{\circ} \mathrm{C}$. Springback of HSSs may be much reduced by a lower forming speed. These phenomena directly correspond to the material's viscoplastic behavior at elevated temperature [152].

Nowadays, aluminum alloys are considered desirable for the automotive and aerospace industries because of their superior corrosion resistance, excellent high-strength to weight ratio, recyclability and high weldability [126]. The application of forming at elevated temperatures to age-hardening aluminum alloys requires knowledge of the interactions between temperature, degree of deformation, precipitation kinetics and exposure time $[153,154]$. The precipitation that can happen during the warm drawing process influences the drawing force and the maximum drawing force depending on the moment the precipitation takes place. A comprehensive review of theoretical and numerical methods (Figure 7) used for prediction of the formability of lightweight materials for sheet metal forming applications can be found in [155]. The increase in plastic strain during the two-stage warm drawing process resulted in a gradual increment in cup wall strength as substantiated with the microhardness results. 


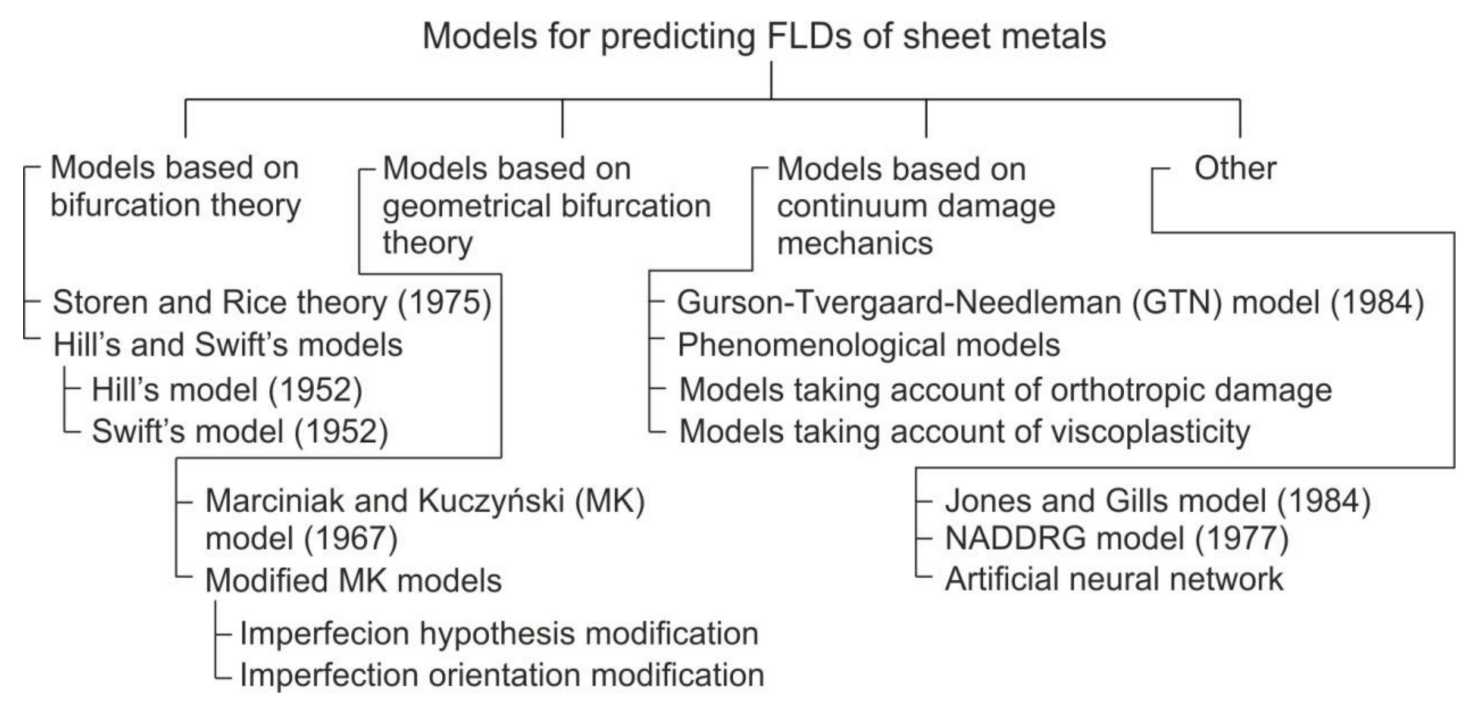

Figure 7. Numerical and theoretical models used for the prediction of formability.

Warm forming is an effective solution to improving formability for both heat-treatable and non-heat-treatable aluminum alloys. The investigations on this topic in the last decade are mainly focused on the development of effective numerical codes for thermomechanical FE-based analyses [156,157], design of warm forming tools [123,141], modeling of the mechanical behavior of materials at elevated temperatures $[139,158-160]$ and the development of alternative warm forming methods [161].

Magnesium, with a better recyclability and higher strength-to-density ratio, has become an alternative to aluminum and steel, especially in the automotive industry which is looking for ways to limit the emission of greenhouse gases and meet the demand by customers for fuel efficient vehicles [154,162]. The room temperature formability of magnesium alloys strongly depends on deformation twinning and texture [163]. Although magnesium alloy sheets have low ductility at room temperature due to the small number of slip systems, it is well-known that formability at temperatures around $200^{\circ} \mathrm{C}$ can be drastically improved [164]. As the temperature increases, prismatic and pyramidal slip systems can be activated, thus improving the formability [165]. As shown by Maksoud et al. [166], as the forming temperature of magnesium alloy increased from $300{ }^{\circ} \mathrm{C}$ to $400{ }^{\circ} \mathrm{C}$, the grain size quickly increased, and performance decreased.

The formability of sheet metal not only depends on the material's properties, but also on the friction on the tooling/workpiece interface [167,168]. According to the study by Abu-Farha et al. [169], the fissure orientation in the specimens tested using the elevated-temperature pneumatic stretching test apparatus (Figure 8) was also affected by the rolling direction and relative size of major strain and minor strain.

In recent years, many researchers have looked at the process of deep-drawing laminated sheets [125]. However, most of the investigations carried out on laminated sheets were conducted during the deep drawing process at room temperature $[170,171]$. A comprehensive investigation on the warm deep-drawing process (Figure 9) in AA1050/St304 and AA5052/St304 laminated sheets at three different temperatures and various grain sizes was carried out by Afshin and Kadkhodayan [126]. It was found that the growth of grain size led to an increasing coefficient of friction (COF) which had negative effects on the material formability. Raising the blank holder force had a dominant impact on formability, which led to the warm deep-drawing process being performed with a smaller load requirement at higher temperatures. 


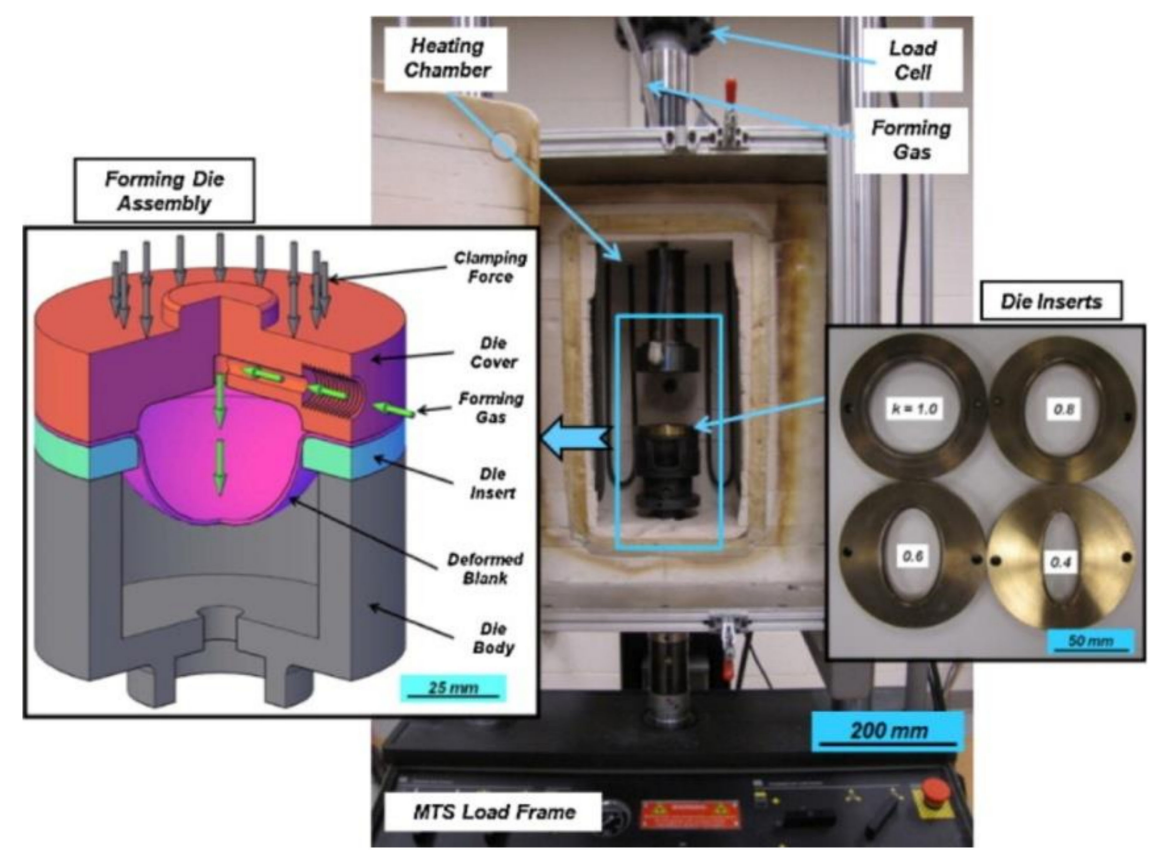

Figure 8. View of the elevated-temperature pneumatic stretching test apparatus, showing an enlarged schematic diagram of the set up including the forming die assembly (left), furnace with forming assembly (central) and die inserts (right) (reproduced with permission from [169]; copyright (C) 2012 Elsevier B.V.).

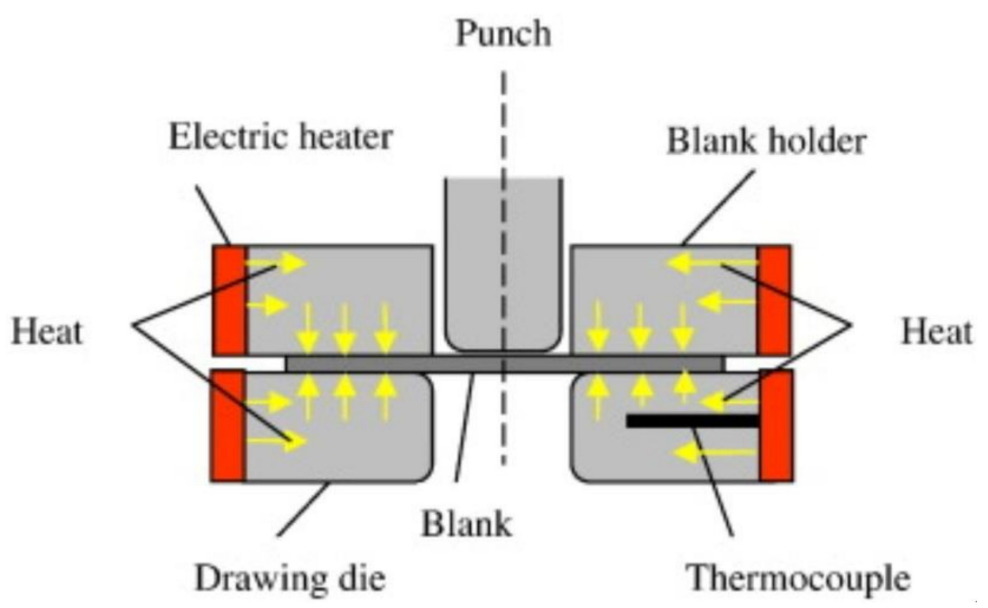

Figure 9. Schematic diagram of the equipment for deep-drawing (reproduced with permission from [126]; copyright (c) 2015 Elsevier, Ltd.).

The main problems occurring during SMF processes at elevated temperatures are wear and high friction due to high adhesion of the workpiece material to the tool surface and surface initiated fatigue $[172,173]$. An understanding about the occurrence and prevention of a galling mechanism $[172,174]$ is investigated by using special tribotesters $[172,175]$ or typical tribometers [176] destined for wear analysis.

Friction in warm and hot forming conditions is in general higher that in the case of cold forming conditions. The tribology of warm and hot metal forming is very much of concern because there are several influential variables such as materials, surface coatings, lubricants, contact pressure and temperature $[177,178]$. It usually requires special heavy-duty lubricants with fillers. In warm and hot metal forming, the graphite-based "black" lubricants have been abandoned by many industries now using "white" lubricants on either a polymer base, carvone base or liquid glass base [162]. A review of 
related effects of oxidation, surface coating, lubrication and a tribometer in metal forming at elevated temperatures can be found in these papers $[125,179,180]$.

\section{Incremental Sheet Forming}

\subsection{Background}

In incremental sheet forming (ISF), called "dieless forming", a sheet metal blank is simply clamped with the help of a blank holder and a tool with a hemispherical end incrementally forms the sheet into the desired shape. The basis for the development of the incremental forming method is the patent developed by Leszak [181] in 1967 before it was technically feasible. Initially the methodology of single-point incremental forming (SPIF) methods was based on conventional spinning, allowing one to obtain axisymmetric parts. Widespread use of numerically controlled machines and robots allowed the introduction of ISF into industrial practice. Some researchers have developed special purpose machines to carry out incremental sheet forming [182-186]. Although ISF has a very reasonable economic performance in small-lot production and is fine for manufacturing those elements which cannot be obtained using conventional sheet forming methods, several attempts have been made to use the forming technique in mass production [187-189]. There are many factors which influence the applicability of ISF and the accuracy of the parts thus formed [190-194]: tool path strategy, mechanical properties of the sheet metal (material anisotropy, ability to strain harden, elastic properties), the technological parameters (i.e., tool diameter, tool path strategy, depth value between two tool passages, tool rotational speed, friction conditions) and design parameters (geometry of the product, sheet thickness). One surface of the drawpiece in SPIF revealed small linear grooves as a result of the interaction of the tool tip with the workpiece (Figure 10). The surface finish of the second side of the drawpiece is the result of small-scale roughness induced by large surface strains which leads to an orange peel phenomenon (Figure 11) [195].

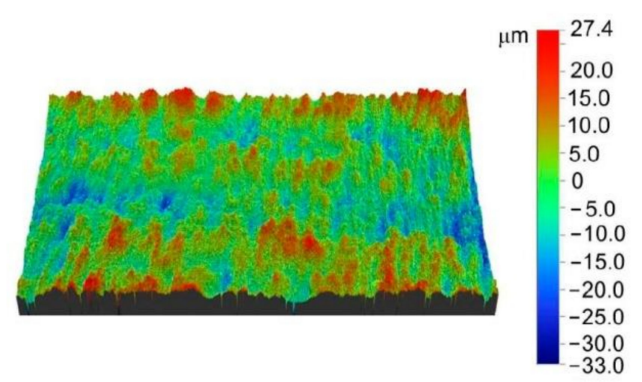

(a)

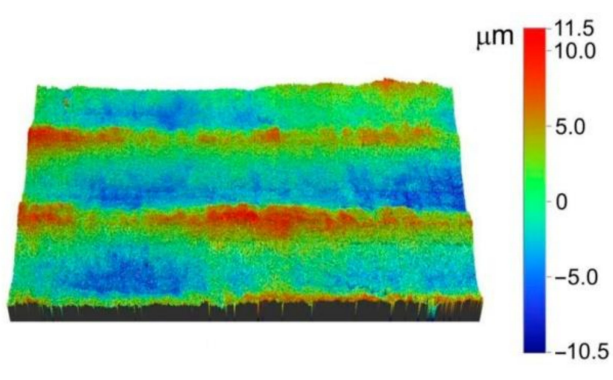

(b)

Figure 10. Surface topography of the outer (a) and inner (b) surface of a conical drawpiece with a slope angle of $71^{\circ}$.
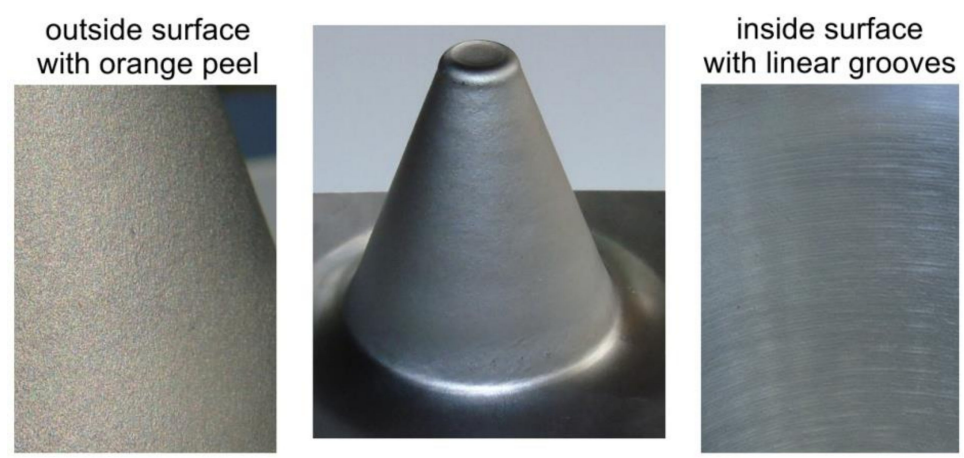

Figure 11. View of the inner and outer surface of a conical drawpiece. 
ISF is mainly carried out in the four different ways shown in Figure 12, which are also considered as process principles. Figure 12a represents SPIF in which a rotating tool moves over the clamped edge of the workpiece and produces the desired shape. The SPIF type is a two-point incremental form (TPIF), which can be produced using a partial die (Figure 12b) [196] or a specific die (Figure 12c) [197], which is also is called positive incremental forming (PIF), while all the other methods are negative incremental forming (NIF) [198]. In the TPIF methods (Figure 12d), there is an additional movement of the fixing grip of the plate, which produces effects on the improvement of the accuracy of the drawpieces [196,199].

Parallel investigations are also conducted on the use of a freely rotating [200] or non-rotatable tool [201]. The linear motion of the tool is usually in the range of $300-3000 \mathrm{~mm} \cdot \mathrm{min}^{-1}$. The rotational speed of the spindle can reach up to $2 \cdot 10^{3} \mathrm{rpm}$ [201], however in most SPIF methods the rotational speed of a spindle with a rounded tip is in the range 200 to $800 \mathrm{rpm}$.
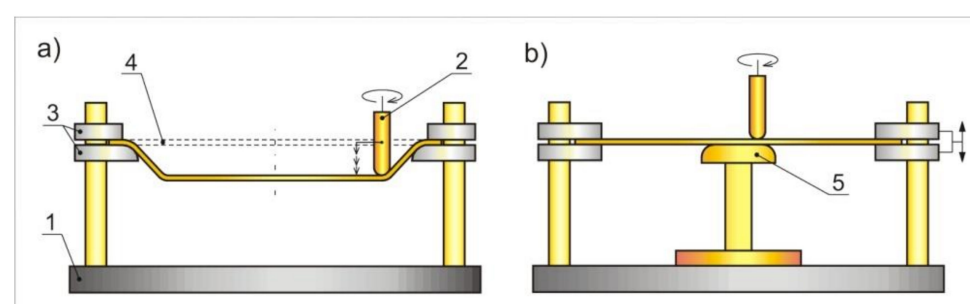

c)

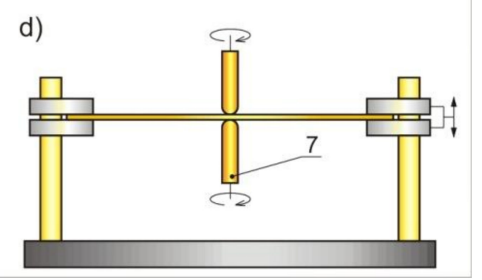

Figure 12. Incremental forming processes: (a) single-point incremental forming (b) two-point incremental forming with a partial die, (c) TPIF with specific die, (d) TPIF with counter tool: 1-base, 2-forming spindle, 3-fixing grip, 4-workpiece (initial position), 5-partial matrix, 6-specific matrix, 7-auxiliary spindle.

\subsection{Incremental Sheet Forming with Metallic Tool}

Most variants of ISF that have been investigated in recent years are intended to fully improve the formability of sheet materials. Xu et al. [183] studied electrically assisted incremental sheet forming with a combination of an electricity-assisted method with double sided incremental forming (E-DSIF) (Figure 13) and the newly designed slave tool force control device used to ensure stable tool-sheet contact (Figure 14). E-DSIF reduced the springback of finished parts during the unclamping and trimming stages.

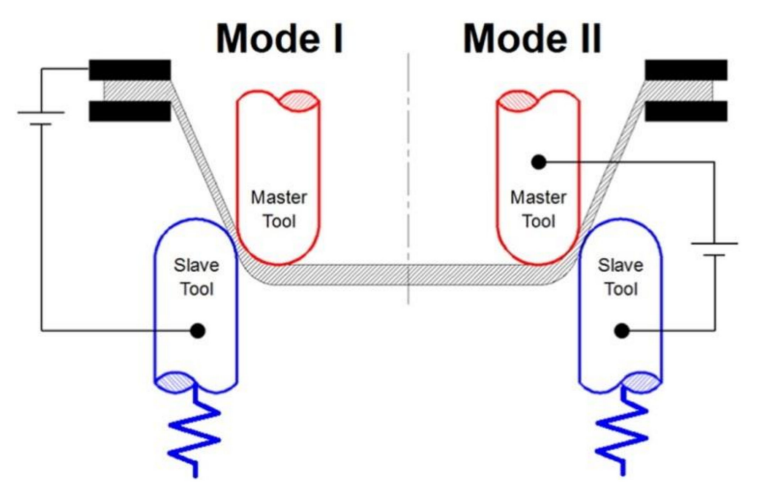

Figure 13. Schematic diagram of the circuit connection in E-DSIF (reproduced with permission from [183]; copyright (C) 2016 Elsevier, Ltd.). 


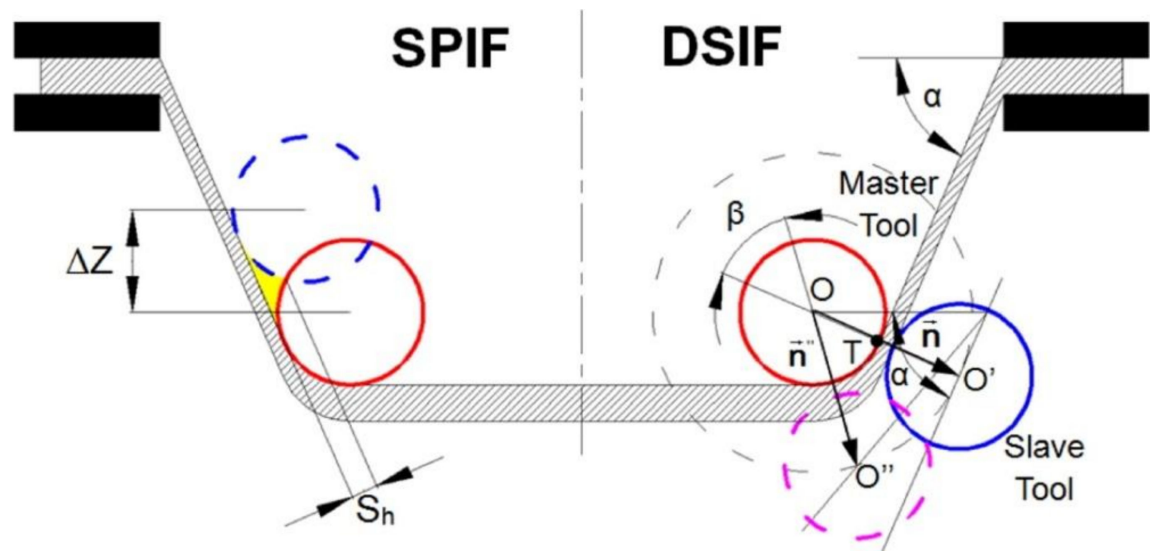

Figure 14. Illustration of the SPIF and DSIF toolpath strategies (reproduced with permission from [183]; copyright (C) 2016 Elsevier, Ltd.).

Al-Obaidi et al. [186] designed a fixture for hot single-point incremental forming of glass-fiber-reinforced polymer (GFRP) supported by hot air. The GFRP sheet was sandwiched between combinations of two polytetrafluoroethylene (PTFE; commonly known as Teflon) layers and metal sheets (Figure 15). The Teflon layer was used to reduce the flow of the melted matrix polymer out of the woven fiber. The aim of the work was to develop a way to shorten the production process for medical implants which will dramatically reduce the cost of their manufacture. In general, the relationship between the depth of the formed part and the heat initiated was found to make the overall workpiece temperature homogeneous. However, as was concluded, the influence of the material and process properties needs broad-ranging investigation to eliminate the defects and to improve the quality of the formed parts.

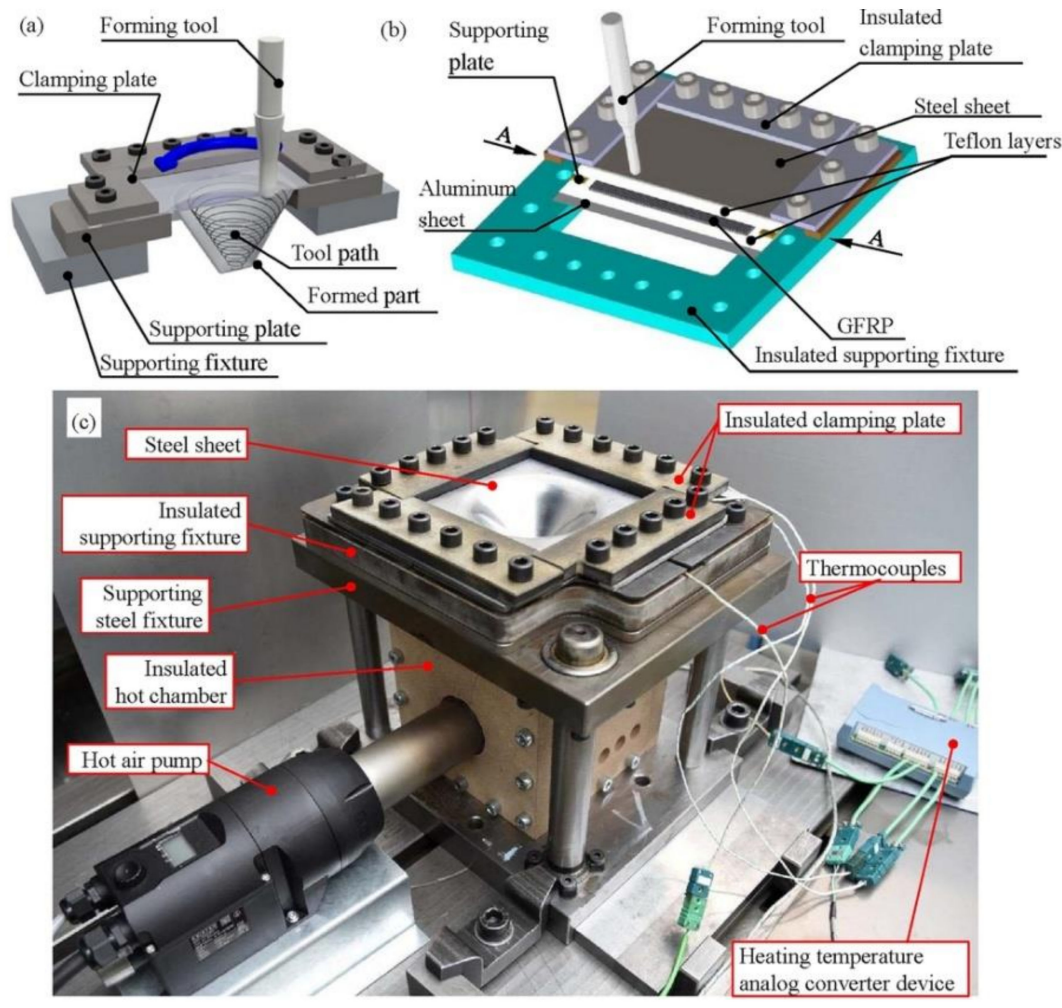

Figure 15. (a) principle of SPIF, workpiece combination, (b) clamping fixture and (c) setup assembly (reproduced with permission from [186]; copyright (c) 2019 The Society of Manufacturing Engineers. Published by Elsevier, Ltd.). 
In recent years, SPIF has been combined with heating techniques to heat up and form difficult-to-form metals into complex shapes by using a laser [202-206], a halogen lamp [207], oil [208], induction heat [209,210] and friction generated by incremental tool application [211] or hot air blowers [212-214]. The apparatus developed by Obaidi et al. [209] and shown in Figure 16 permits local heating of the advanced high-strength steel sheet to elevated temperatures of more than $850^{\circ} \mathrm{C}$, achieving a reduction in the forming forces and residual stress, and improving formability. Some of the authors used the high rotation speed of the forming tool in order to generate friction heat, which can be utilized to improve the formability of the workpiece material [211,215-223]. The formability of hard-to-deform alloys can also be enhanced by direct or indirect electric heat [183,224-235]. Palumbo and Brandizzi [236] used combined heat (electric band + stir rotation friction) to SPIF the deformation of titanium alloy in which static electric heating was employed to pre-heat the sheets. Friction heating was used to further increase the temperature. A detailed state-of-the-art review of the development of heat-assisted incremental sheet forming has been discussed by Liu [237].

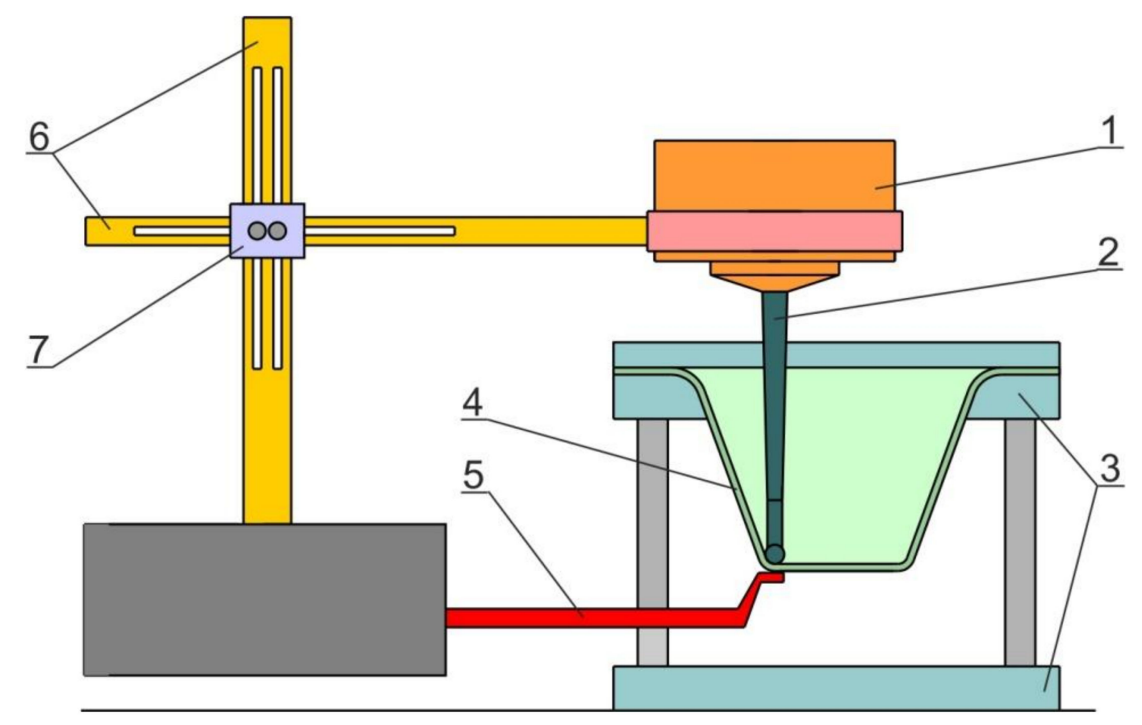

Figure 16. Apparatus for induction heat-assisted SPIF: 1-spindle, 2-tool, 3-clamping fixture, 4-sheet metal, 5-inductor, 6-sliding fixtures, 7-sliding jig.

Excessively high temperature generated at the tool/workpiece interface affects the quality of the sheet surface after forming and the durability of the tool tip [238-240]. The appearance of frictional heat and its effect on the accuracy of the formed part and the formability of the workpiece material has been explored by many researchers in relation to the alloys [200,241,242]. The role of friction in the formability of polymeric materials during the ISF process has been widely discussed by several authors [243-247], who draw conclusions on the important role of friction due to the increase in the temperature of the sheet metal. Much experimental work and many numerical simulations have been conducted to support the designs of the tooltip profile [248,249], coatings of the sheets and tool tips [249,250], tool path strategy and forming parameters [251-253] and residual stresses [254,255] in ISF. It is believed [256] that the tooltip/sheet coatings capable of thermal segregation in the tool-sheet interaction have a huge impact on mitigating the temperature-induced problems in ISF.

A principle of the hybrid combination of stretch forming and SPIF is presented in Figure 17. Stretch forming will not yield the geometry of the final part. Such features as grooves, pockets and corrugations that are too small to be formed by stretch forming are formed using asymmetric incremental sheet forming [257]. In order to minimize thinning and improve the thickness distribution along the formed part, Tandon and Sharma [258] proposed a hybrid incremental stretch drawing process which is designed to combine incremental sheet metal forming with a deep drawing process. Initially the workpiece is deformed by a large sized tool and then an ISF tool formed the final shape of 
the part. It is found that the proposed process is able to reduce thinning by as much as approx. 300\%, considering the same forming depth for the ISF process. Similar investigations on hybrid ISF conducted by Tandon and Sharma [258] and Jagtab and Umar [259] were also studied by Araghi et al. [260] and Lu et al. [261].

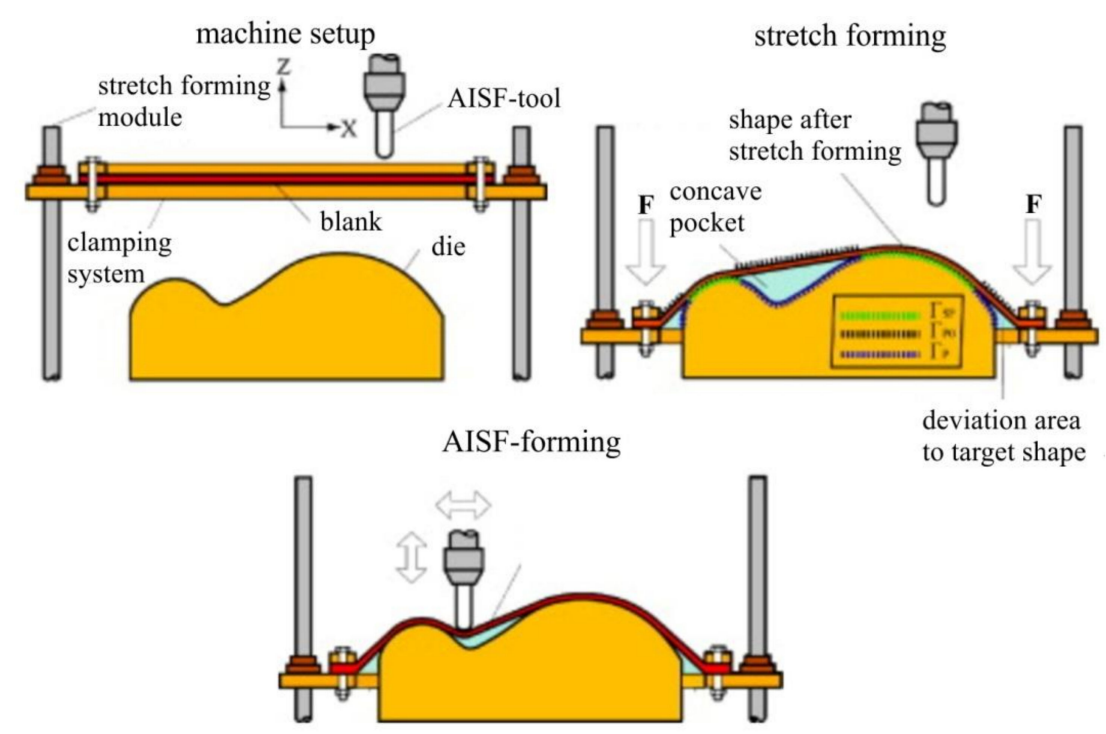

Figure 17. Principle of the combination of processes (reproduced with permission from [257]; copyright (C) 2009 CIRP. Published by Elsevier, Ltd.).

Supporting the sheet in ISF leads to localized deformation under the tool which reduces the flexibility of the ISF process. Therefore, Allwood et al. [262] proposed the use of partially cut-out blanks to create a weakness in the sheet at the perimeter of the required part and to localize the sheet deformation to the region that will be covered by the tool (Figure 18). It was concluded that the use of partially cut-out blanks does not give a useful benefit in ISF. Compared to ISF with no backing plate, partially cut-out blanks develop localized deformation earlier.

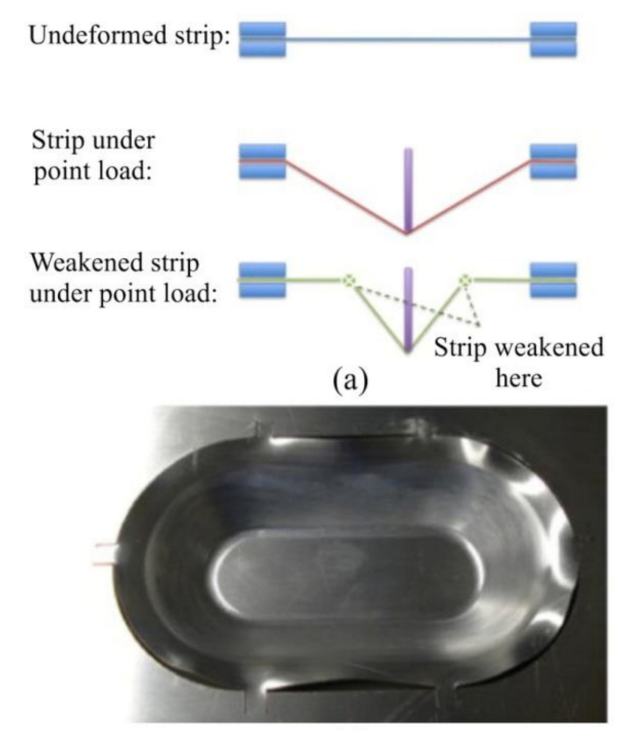

(c)

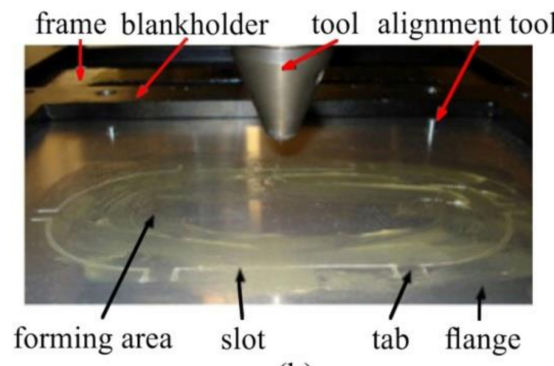

(b)

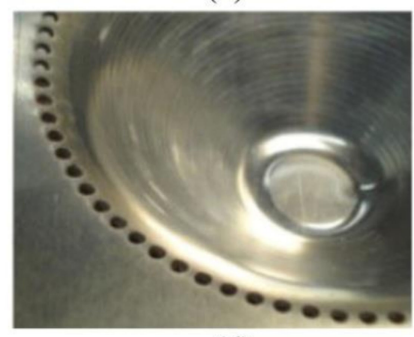

(d)

Figure 18. Partially cut-out blanks: (a) the concept intended to localize deformation, (b) partially cut-out blank before forming and (c) after forming, (d) after successfully forming (reproduced with permission from [262]; copyright (C) 2010 Elsevier B.V.). 


\section{Flexible-Die Forming}

\subsection{Background}

Flexible-die forming on sheet metal employs a pressure-transfer medium as a female die (or punch) and a female punch (or die) [263]. The pressure-transfer medium can be polyurethane, oil, viscous medium, rubber or compressed air. Flexible-die forming technology has undergone rapid development as one of the mainstream forming technologies for thin walled parts. In addition to viscous pressure forming (VPF) and hydroforming by deep drawing (HDD), these technologies are developing rapidly, and aspects of experiments, theoretical analyses, and numerical computation are provided at least once per week. Flexible forming processes, like stamping, deep drawing or bending, are widely used in the aircraft industry to deform difficult-to-form materials by a conventional deep drawing process [264-266].

\subsection{Rubber-Pad Forming}

Rubber-pad forming (RPF) employs a rubber pad on the form block. The rubber pad acts as a hydraulic fluid in exerting a uniformly distributed pressure on a workpiece surface as it is pressed around the form block. With some advantages like ease of operation, reduced springback and high surface quality, rubber-pad forming is widely used in many real-life industrial situations [41,267]. Flexible forming processes, like stamping, deep drawing or bending, are widely used in the aircraft industry to deform difficult-to-form materials by a conventional deep drawing process. RPF has been used to remove surface scratches of the sheet during forming. Several researchers studied the RPF process. Belhassen et al. [268] introduced FEM to analyze the RPF process in AA6061-T4 sheet metal. An elastic-plastic constitutive model with a $J_{2}$ yield criterion and mixed nonlinear isotropic/kinematic hardening coupled with Lemaitre's ductile damage has been adopted during forming.

Irthiea et al. [269] report the results of FE simulation and experimental research on micro deep drawing processes of 304 stainless steel sheets using a flexible die. Two novel approaches were considered with regard to the positive and negative initial gap between an adjustment ring and a workpiece and a blank holder (Figure 19). Initial gaps affect the final cup profiles, in particular at the shoulder corner radius (Figure 20). The numerical predictions conducted in Abaqus/Standard software reveal the capability of the proposed technique to produce micro metallic cups with high quality and a large aspect ratio.

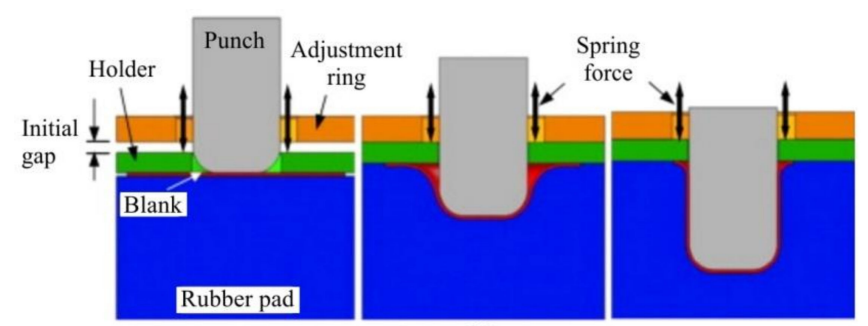

(a)

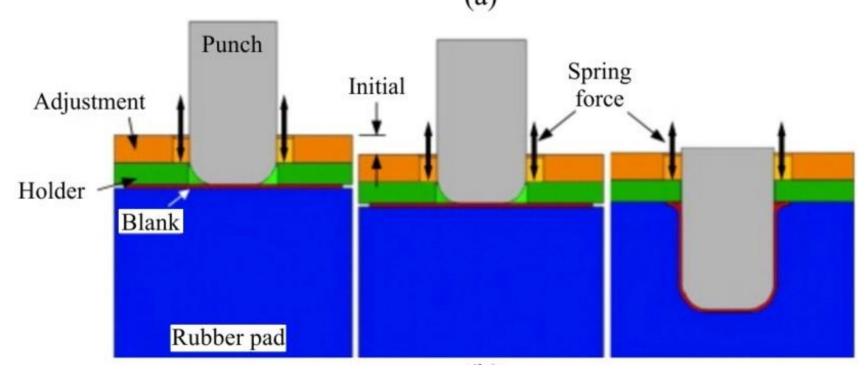

(b)

Figure 19. Flexible forming technology with (a) positive and (b) negative initial gap (reproduced with permission from [269]; copyright (C) 2014 Elsevier, Ltd.). 
The results showed that reducing the initial gap causes a reduction in the initial thickness of the final products. Fabrication of the blank holder with a smooth surface and a rigid punch with a rough surface would improve the formability of the workpiece material. The proposed technique has desirable advantages of significantly lower overall cost and high quality in the fabrication of micro metallic cups.
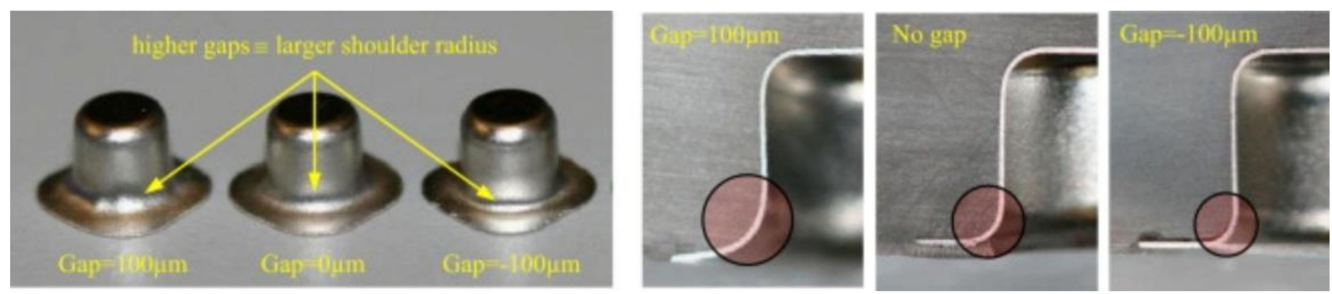

Figure 20. Cups formed with different initial gaps (reproduced with permission from [269]; copyright (C) 2014 Elsevier, Ltd.).

Trzepiecinski et al. [270] analyze the forming process of a fan engine bearing housing made of $17-4 \mathrm{PH}$ stainless steel sheet. Due to the high ratio of yield stress to ultimate tensile strength and large amount of springback of the formed material, the forming process has been divided into two stages in order to ensure suitable shape and dimensional accuracy of the drawpiece: forming of the drawpiece using a rubber punch (Figure 21a) and calibration of the drawpiece at elevated temperature. A 3D finite element-based coupled thermomechanical model was built using the commercial FE-package eta/DynaForm. The distribution of the drawpiece shape error (Figure 21b) obtained by the GOM ATOS system and thickening measurements confirmed that the experimental method thus developed is suitable for the manufacture of bearing housings for aircraft fan engines. As predicted by the eta/Dynaform program, the component is free from defects (Figure 21c). The formation of wrinkles was observed on the free surfaces of the part, but this part of the drawpiece is cut off after the forming process is finished.

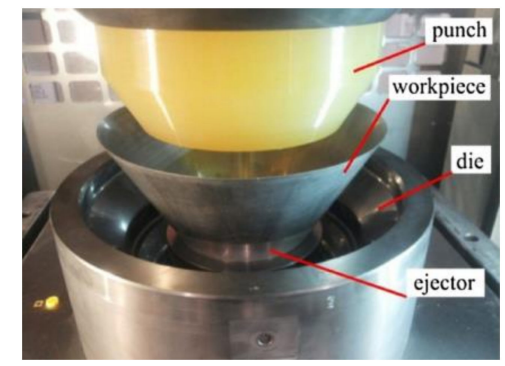

(a)
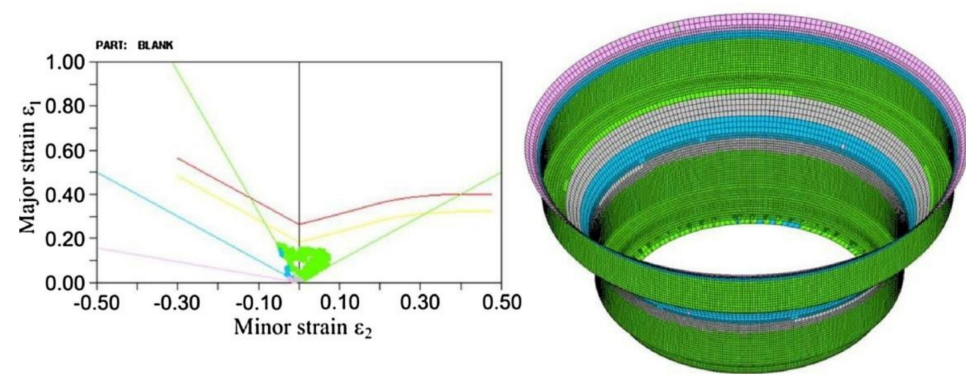

(c)

(b)
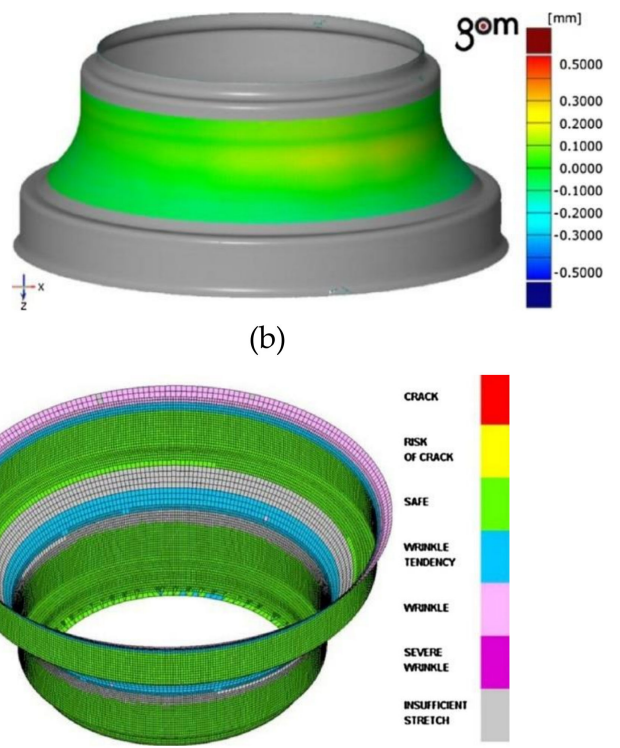
Figure 21. Rubber-based forming: (a) tool setup, (b) The distribution of the shape error obtained using
the GOM ATOS instrument, (c) The major and minor strains and FLD (left) and the final shape of the bearing housing (right) after the first stage of forming (reproduced with permission from [270]; copyright (C) 2017 The Society of Manufacturing Engineers. Published by Elsevier, Ltd.). 
The rubber forming process (RFP) has also been successfully applied to straight flanging. Flanging is used to deform the edge of the part to create a mating surface to increase the stiffness of the part. The influence of process parameters (time and pressure) on the RFP was studied by Chen et al. [271]. The key phenomenon which limits the ability to obtain a part with the desired geometry is springback. It was found that springback of the straight angle increased with a decrease in blank thickness. An increase of forming pressure and time of rubber forming had little effect on the springback when the blank coincided with the die face. It should be pointed out that the springback of flanging in the rubber forming process was smaller than that of stamping and can be eliminated with a ratio of the bending radius $r$ (die radius) to the sheet thickness $t: r / t<2$.

Rubber forming technology is also a method that can feasibly be used for micropatterning of thin metallic bipolar plates [272]. In this process, the workpiece is placed on the rubber pad and then the blank and the rubber pad are pressed simultaneously by the die. With this technology, the force from the upper die and the repulsive force resulting from elastic deformation of the rubber pad are transmitted to the entire surface of the workpiece. Jin et al. [272] analyzed the effects of the hardness and thickness of the rubber pad, physical properties of the materials, forming speed and pressure of the punch on the channel depth. They found that (i) the lower the hardness of the rubber pad, the more beneficial it was for the deformation of the rubber and the channel is deeper (ii) the thicker the rubber pad, the deeper was the channel in the bipolar plate due to it not losing the load imposed by the punch toward the outside. Most researchers studied the forming of a straight channel based on the 2D models.

Liu et al. [273] studied the deformation mechanisms during the forming of a channel in metallic bipolar plates (Figures 22 and 23) using the two styles of deformation (concave and convex). Experimental methods and numerical simulations showed that the thickness distribution of the parts manufactured by the concave approach is less uniform than that of the convex shape. The ratio of channel height $h$ to rib width $w(h / w)$ is a determining parameter in obtaining the desired geometry of the part. For the concave deformation style, the maximum thickness reduction also increases as the value of $h / w$ increases. By contrast, for the convex style, the maximum thickness reduction decreases with increasing $h / w$.

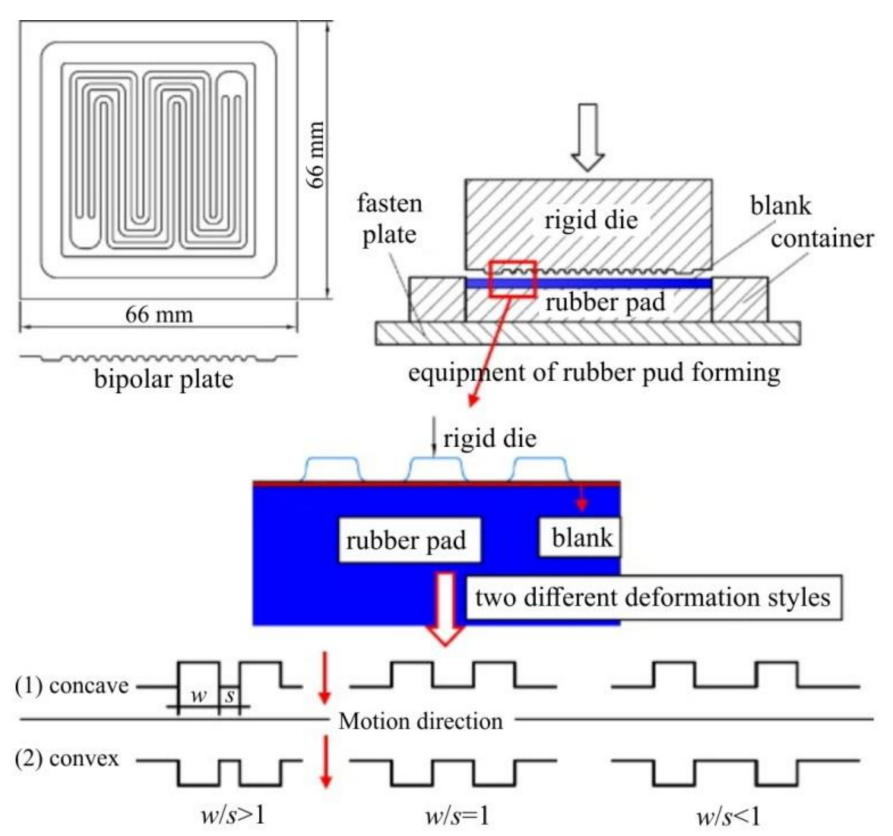

Figure 22. Fabrication of a bipolar plate by rubber-pad forming (reproduced with permission from [273]; copyright (C) 2010 Elsevier B.V.). 

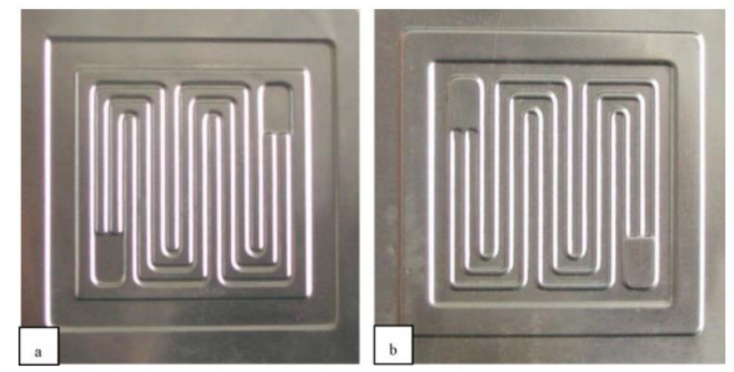

Figure 23. Bipolar plate fabricated by rubber-pad forming: (a) front of the bipolar plate and (b) back of the bipolar plate (reproduced with permission from [273]; copyright (C) 2010 Elsevier B.V.).

\subsection{Multipoint Die Forming}

A multipoint forming (MPF) die uses reconfigurable matrices of pins, which can move normally to the die base to create the die surface. A reconfigurable tool consists of a large number of adjustable pins, the form of the ends of which define the specified shape of the part [274]. Over the years, several designs of reconfigurable tooling have been developed [275-277]. The MPF process is very flexible permitting rapid changes in tool configuration to be accommodated without affecting tooling costs [278]. The concept of the use of a discrete-pin die for forming sheet metal was first introduced about 40 years ago [279].

Many investigations have been conducted in recent years to develop the multipoint forming technique. Most of these are focused on avoiding defects without taking into account the effects of the forming process on the quality of the finished parts. Paunoiu et al. [280] developed numerical simulation models using dynamic FE-based Dynaform software and investigated the effect of tool geometry and the use of an elastic cushion on deformation behavior. The elastic cushion had a positive effect on the part surface and a negative effect on shape accuracy. The elastic cushion had a negative effect on shape accuracy and a positive effect on the part surface.

To reduce tool costs to a significantly lower value compared to that for conventional reconfigurable MPF tools, the multipoint sandwich forming (MPSF) was developed. Pins are used only in the bottom die and the space between them is large (Figure 24), so that fewer of them are required to span a given area and their height is adjusted manually using their threaded shanks [274]. The upper die is composed of urethane. To provide a continuous surface for the bottom die, a steel sheet is deformed between the appropriately positioned pins and the urethane upper die [274].

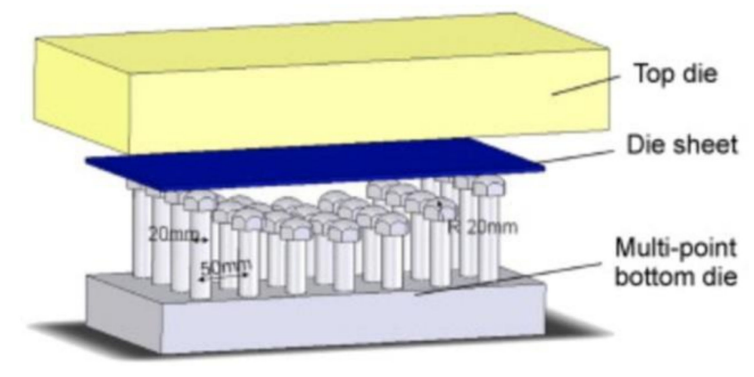

(a)

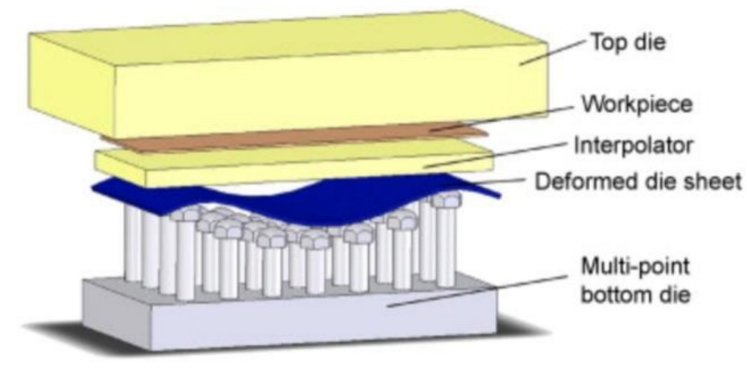

(b).

Figure 24. Multipoint sandwich forming; set up for the deformation of (a) die sheet and (b) workpiece (reproduced with permission from [274]; copyright (C) 2008 Elsevier, Ltd.).

Multifunctional light-weight sandwich panels, due to their profitable load-bearing characteristics, have been widely used in a variety of applications such as ship structures, aircraft, high-speed trains and the automotive industries [281,282]. 
Sandwich panels are mostly limited to the flat-panel type however in many engineering applications it is necessary to use three-dimensional panels rather than flat sheets $[170,283,284]$. This creates the need to work on effective methods for forming honeycomb-type structures. Cai et al. [285] applied an MPF tool (Figure 25a) to form double curved sandwich panels with egg-box-like (EBL) cores. Among various types of topological configurations of sandwich cores, EBL-cored panels are ultra-lightweight structures. Experiments using MPF- and FE-based analyses reveal that the formability of a sandwich panel with EBL cores (Figure 25b) in the plastic forming process is mainly dominated by tree mechanisms: face sheet plastic dimpling, the failure modes of face sheet plastic wrinkling and core cell fracture. The analytical formulations presented allow one to facilitate the prediction and successful prevention of failure modes in the plastic forming process of sandwich panels (Figure 26).

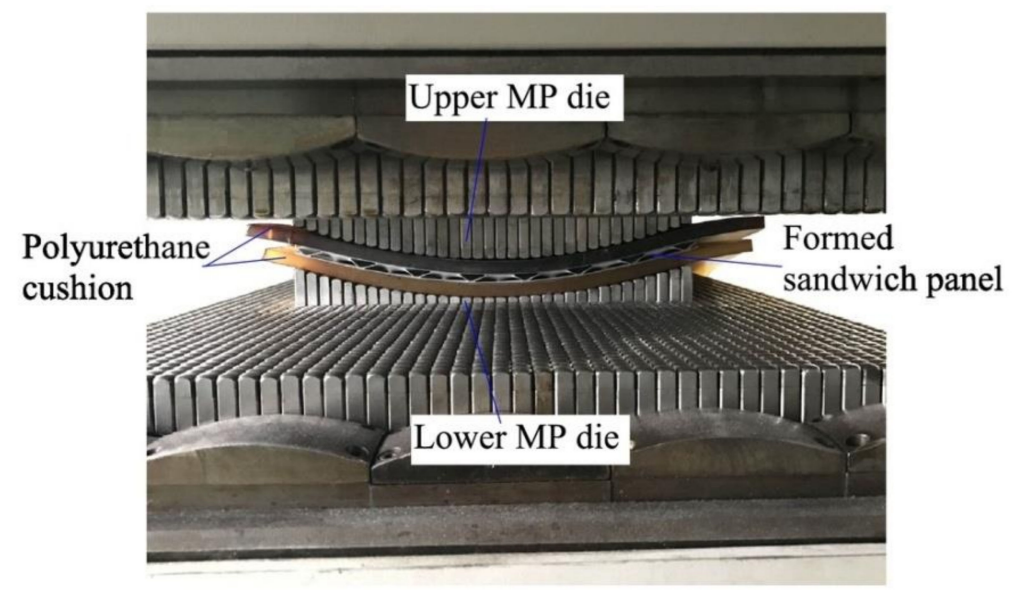

(a)
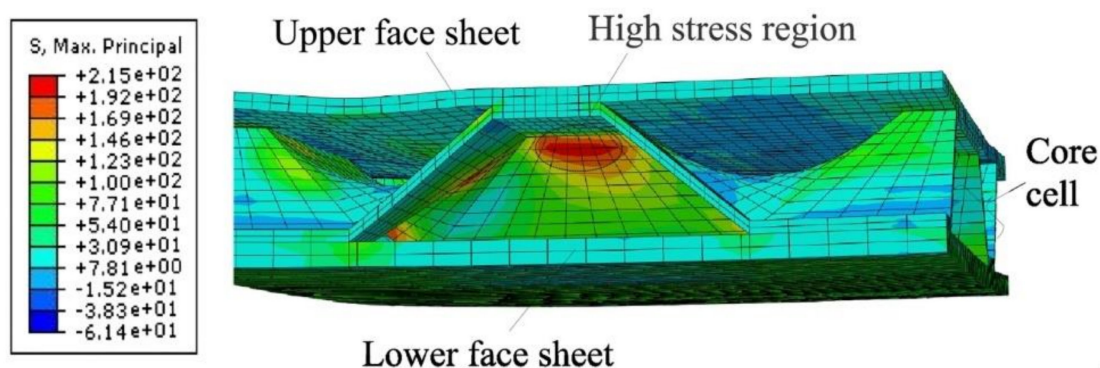

Lower face sheet

(b)

Figure 25. (a) Multipoint forming (MPF) of egg-box-like (EBL)-cored sandwich panel and (b) distribution of maximum principal stress on the EBL core cell of the panel (reproduced with permission from [285]; copyright @ 2018 Elsevier, Ltd.).

(a)

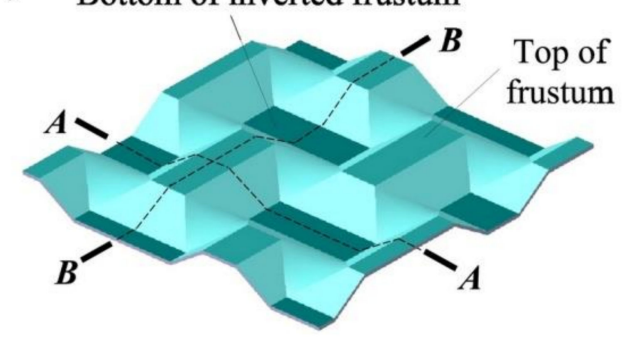

(b)

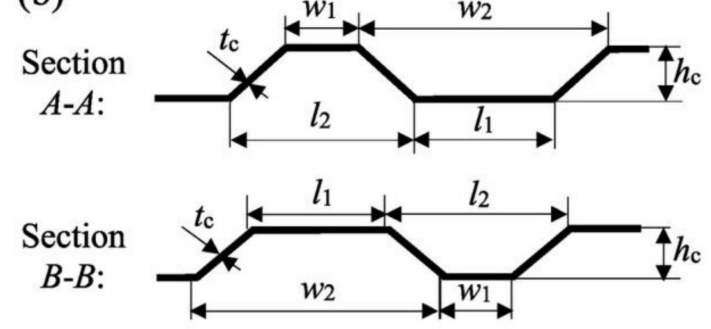

Figure 26. (a) sketch of the EBL core and (b) cross-sectional geometry of the EBL core (reproduced with permission from [285]; copyright (C) 2018 Elsevier, Ltd.). 
The cylindrical bending process of bidirectional trapezoidal core sandwich structures has been very limited in recent decades. In 2018 Liang et al. [286] applied multipoint bend-forming (MPBF) to aluminum alloy welded metal sandwich panels with a new type of bidirectional trapezoidal core (Figure 26). The main forming defects of the sandwich panels and the deformation characteristics were analyzed numerically. The dimple and straight plane effects are found to be the most frequent forming defects in the bend-forming process. In addition, the main factors that affect forming defects are bending radius and face sheet thickness.

\subsection{Solid Granular Medium Forming}

Solid granular medium forming (SGMF) adopts spherical non-metal or metal particles with a diameter in the range of $0.05-2.00 \mathrm{~mm}$ as filling medium [287]. The particle medium can overcome loading induced by liquid media under elevated temperature conditions. Furthermore, friction produced by the particles adhering to the sheet surface results in a uniform wall thickness of the formed parts. The advantage of SGMF over the remaining flexible-die forming techniques is good surface quality, high dimensional precision, simple implementation, high production flexibility and a better fit of the die [287]. SGMF has found particular application in the manufacturing of workpieces with rigorous requirements with regards to geometric accuracy and surface finish. This technology can simplify complex sheet metal production and provides production with good flexibility, fine structures and less elasticity. Although LSDF requires high pressure from the liquid-pressure system, a sophisticated liquid pressure system design and practical cavity sealing plans, it provides for the production of fine structures with good flexibility [263].

Chen et al. [288] implemented the press hardening process (Figure 27) for tubular components by using SGMF, which have much higher stiffness when compared to sheet metal parts. A multitype granular medium (quartz sand, sintered zirconium silicate and cerium-stabilized zirconium dioxide) reduced the interfacial friction force and showed better formability. The effects of interfacial friction between the particles of the granular medium and the formed sheet were represented by tube length, type of granular medium and the COF.

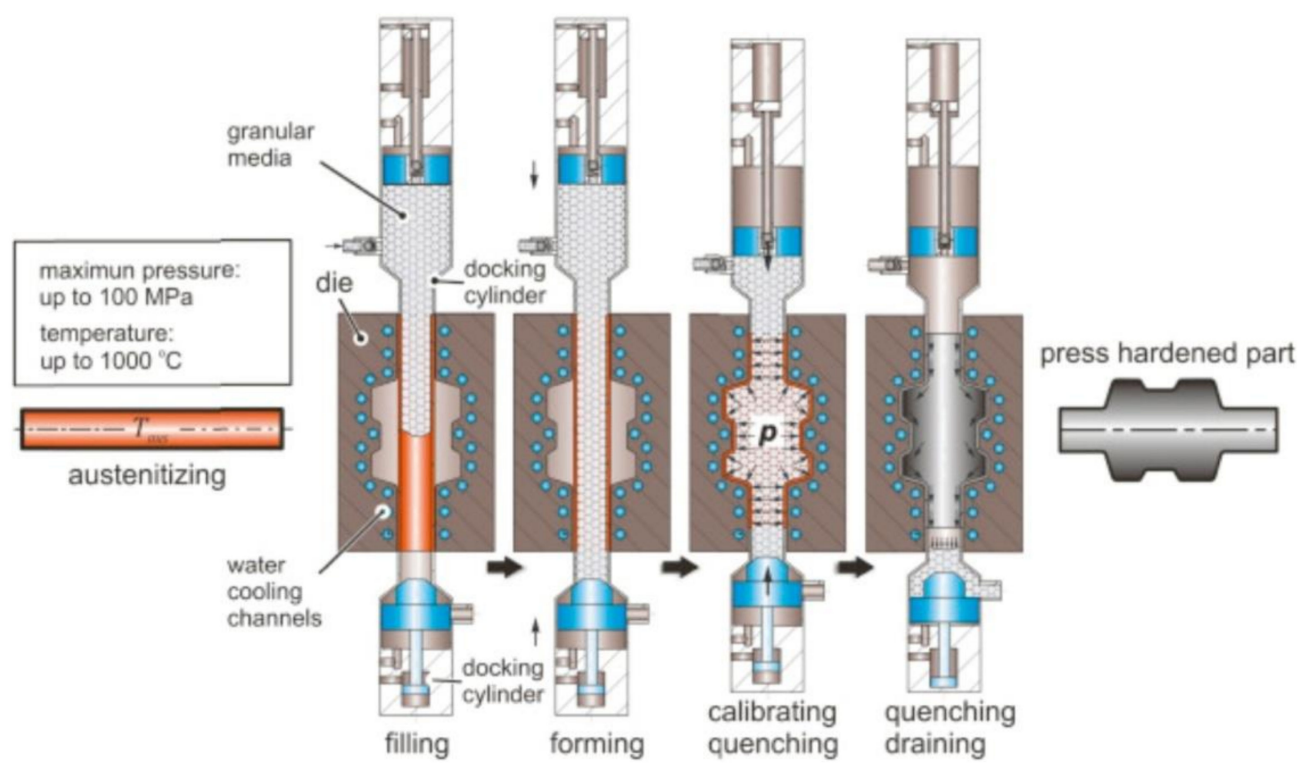

Figure 27. Granular medium-based tube press hardening (reproduced with permission from [288]; copyright (C) 2015 Elsevier B.V.).

The advantages of coupling FEM and DEM solutions are as follows: applicability to non-axisymmetric geometries of components, automatic detection and solution of the contact phenomena between the granular medium and the workpiece, and applicability to quasi-static 
processes which contain complex friction contact conditions and large deformations. Dong et al. [289] carried out FE-based numerical simulation of SGMF of back pressure deep drawing and concluded that the forming of thin-walled rotary parts with complex cross-sections is enormously influenced by the process parameters: the back pressure load and the blank holder gap. Dong et al. [51] applied extended Drucker-Prager linear FEM-based numerical simulation of SGMF of the AA6061 extruded tube (Figure 28). The effects on the forming performance of the workpiece and the approach to the control of blank holding were analyzed through this model. The results of the investigations confirmed the ability of the constitutive equation to be reflected in the establishment of the material model of the granule medium.
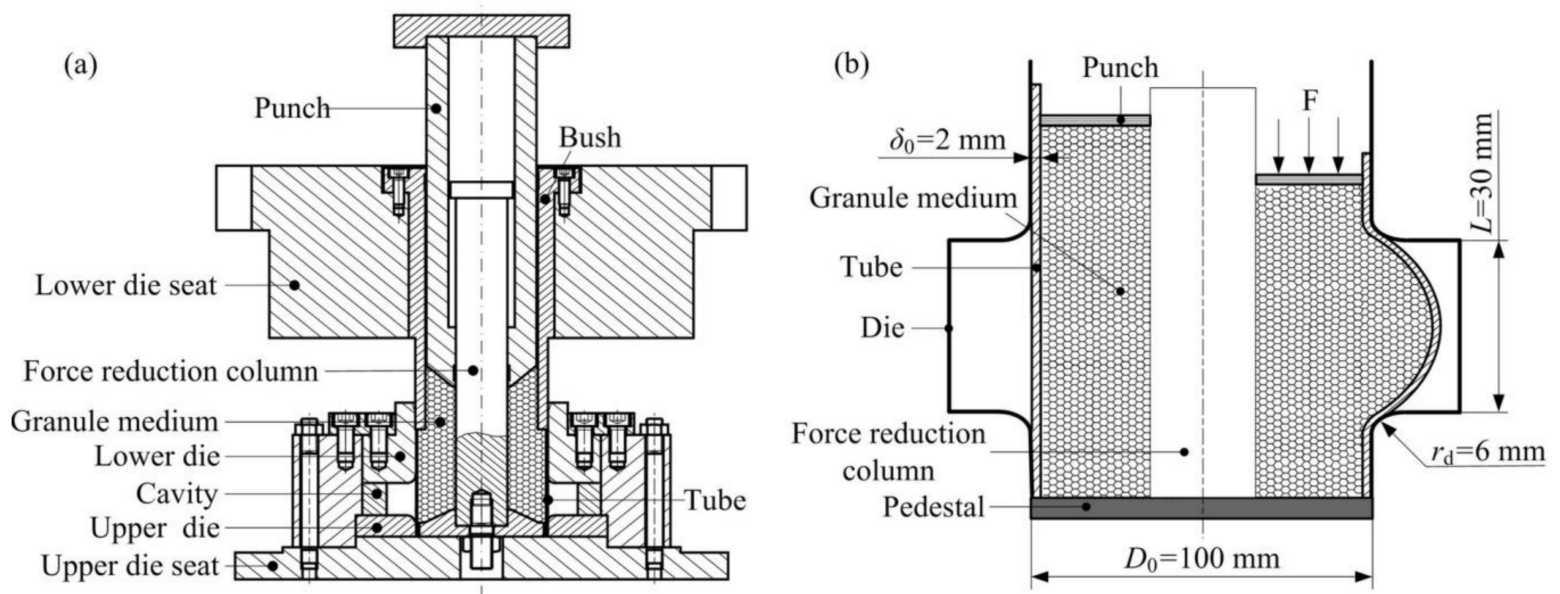

Figure 28. (a) forming mold design and (b) finite element method (FEM)-based numerical model (reproduced with permission from [51]; copyright (C) 2017 Elsevier B.V.).

\section{Electromagnetic Sheet Forming}

Electromagnetic forming (EMF) is a kind of powerful and high-speed forming technique where the strain rate of the sheet metal is of the order of approximately $10^{3} \cdot \mathrm{s}^{-1}[287,290-294]$ and the deformation velocity can reach up to $300 \mathrm{~m} \cdot \mathrm{s}^{-1}$ [295]. EMF uses a Lorentz's force occurring in a pulse magnetic field generated by circuits conducting high-oscillation electric current [296]. Thin metallic sheet can be accelerated to high velocity in a period of a millisecond [297]. During EMF, a large electric current pulse passes through a conductive coil by discharging a capacitor bank. The electric current produces a transient magnetic field around the coil that induces eddy currents in a metal workpiece.

EMF has many advantages that make it an attractive alternative to conventional SMF methods:

- It is an environmentally friendly process; no lubricants are needed;

- There is no mechanical contact with the work piece;

- The formability limit is increased during electromagnetic forming due to high deformation velocity, the forming limit of the aluminum alloys can be improved by $10 \%-14 \%$ [298] or even 2-3-fold [299], compared to the quasi-static loading conditions;

- Controllability and repeatability of the formed parts are ensured;

- The greatest advantage is a significant increase in workpiece ductility over conventional SMF methods;

- Parts formed by EMF possess the merits of low springback [300], uniform strain distribution and good surface quality.

In the last decade, EMF has been studied experimentally and numerically by many researchers. The nonuniform deformation behavior results in a reduction in the shape and dimensional accuracy of the final part. To precisely control the material behavior in EMF and obtain parts without defects, various techniques were employed, such as selecting optimized process parameters [301,302], electromagnetic 
calibration [300,302,303], applying two-step forming [304] and using tailored forming coils [305,306], prediction of formability and failure [307]. The current methods for the evaluation of limit strains at the onset of necking and fracture have recently been discussed in [308].

Cui et al. [309] proposed electromagnetic incremental forming (EMIF) technology in which it is feasible to produce a large part with a small working coil and small discharge energy, which enhances the flexibility of EMF. The principle of EMIF is shown in Figure 29a. The magnetic force is used to launch the sheet at very high speeds and to obtain the desired shape. Figure $29 \mathrm{~b}$ shows that the working coil moves to a specific position and the metallic sheet deforms in many cycles of charge and discharge. Finally, the local deformation accumulates into the final deformation as shown in Figure 29c. Two different strategies are proposed to predict the electromagnetic incremental sheet and tube forming process. For the first method, the coil can move directly to a special position and remesh technology is used to consider the effect of the workpiece deformation and the movement of the coil on magnetic analysis. In the case of the second method, technology like the "birth-death element" is used to indirectly describe the movement of the coil. It was found that the second method cannot be used for the EMF process if an overlap region exists in two adjacent discharge regions.

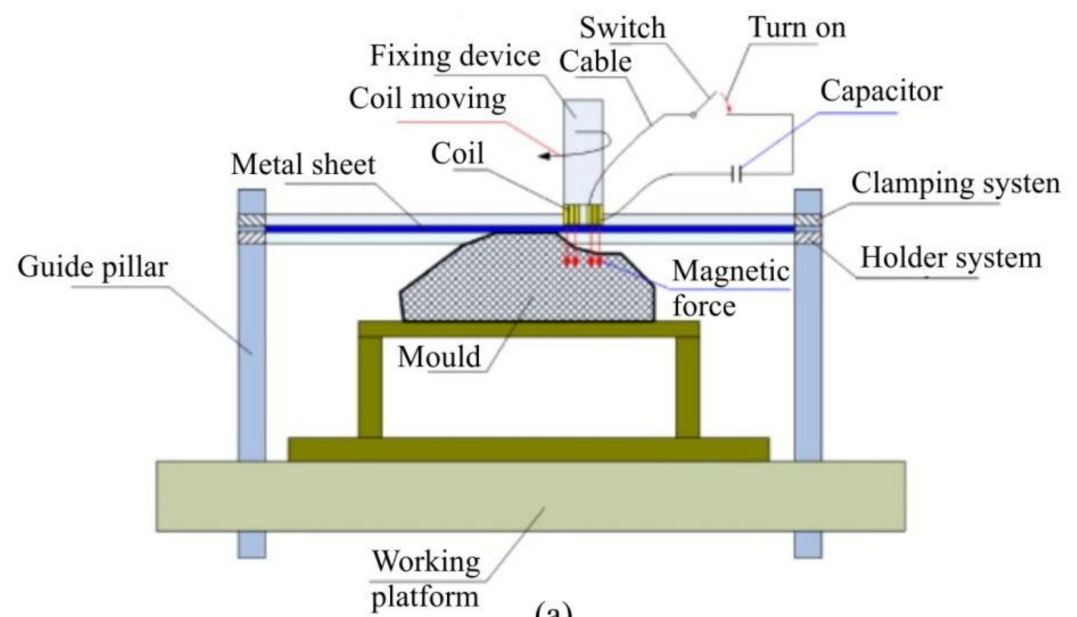

(a)

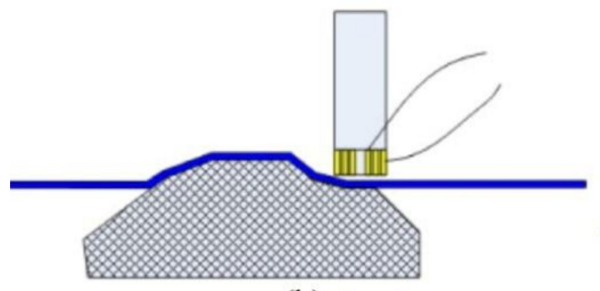

(b)

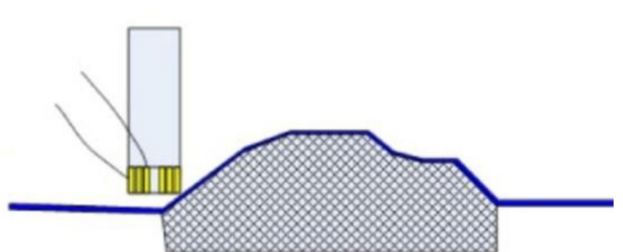

(c)

Figure 29. (a) schematic diagram of the forming tool, (b) local deformation and (c) termination of deformation (reproduced with permission from [309]; copyright (C) 2014 Elsevier B.V.).

Lai et al. [310] proposed a forming facility for large sheet metal forming which is lightweight compared to other conventional tools. The EMF facility they developed consists of four major sub-systems: a forming coil system, a die system, an inertia confinement system and a pulsed electromagnetic blank holding force system (Figure 30). The pulsed electromagnetic blank holding force system is a newly developed approach that utilizes a pulsed attractive Lorentz force as a blank holder force. The resulting measurements of sheet thickness and deviation from the desired shape are very promising, providing forming of the large sheet metal components. Tan et al. [311] introduced EMF to form a panel with stiffened grid ribs. The forming rules of the grid-rib panels during the EMIF process were revealed by analyzing the evolution of the stress, strain and forming depth. It was found that the forming depth is mainly attributed to the forces exerted on the web, although electromagnetic force is applied on both the ribs and the web. 
Because of the large degree of stretching and bending deformation in hole-flanging regions [312] and the relatively low formability of aluminum alloys at room temperature [313], the workpiece tends to tear or crack along the circumference at the flanged edge formed by conventional stamping [314,315].

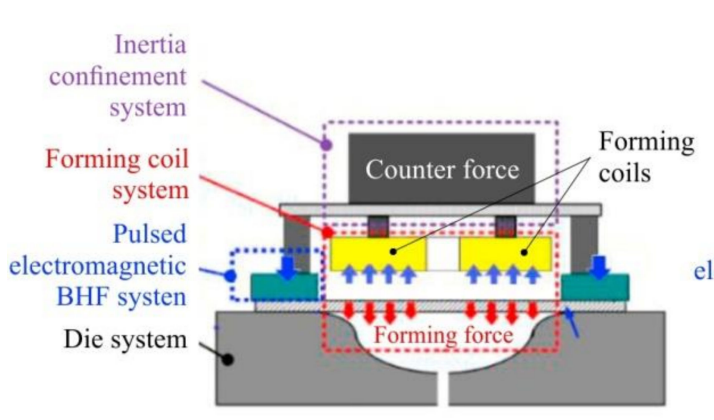

(a)

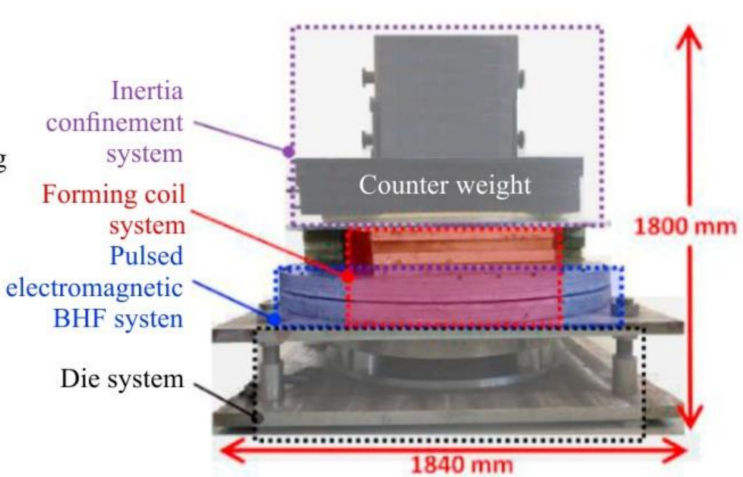

(b)

Figure 30. Electromagnetic forming: (a) schematic diagram and (b) experimental setup (reproduced with permission from [310]; copyright (C) 2017 Elsevier, Ltd.).

To overcome this problem, Su et al. [303] proposed a new two-step electromagnetic forming process which combines EMF with electromagnetic calibration for local features of large-size sheet metal parts. During this process, the workpiece is first electromagnetically formed by a flat spiral coil and then electromagnetically calibrated by a helical coil with a similar shape to the final profile of the workpiece (Figure 31). The experimental results show that there are critical discharge voltages for both EMF and electromagnetic calibration which lead to the minimum die-fitting gap. It was also found that the proposed two-stage forming process improved the stress distribution in the workpiece and reduced the bending moment, which is responsible for the minimization of springback and shape and dimensional errors.
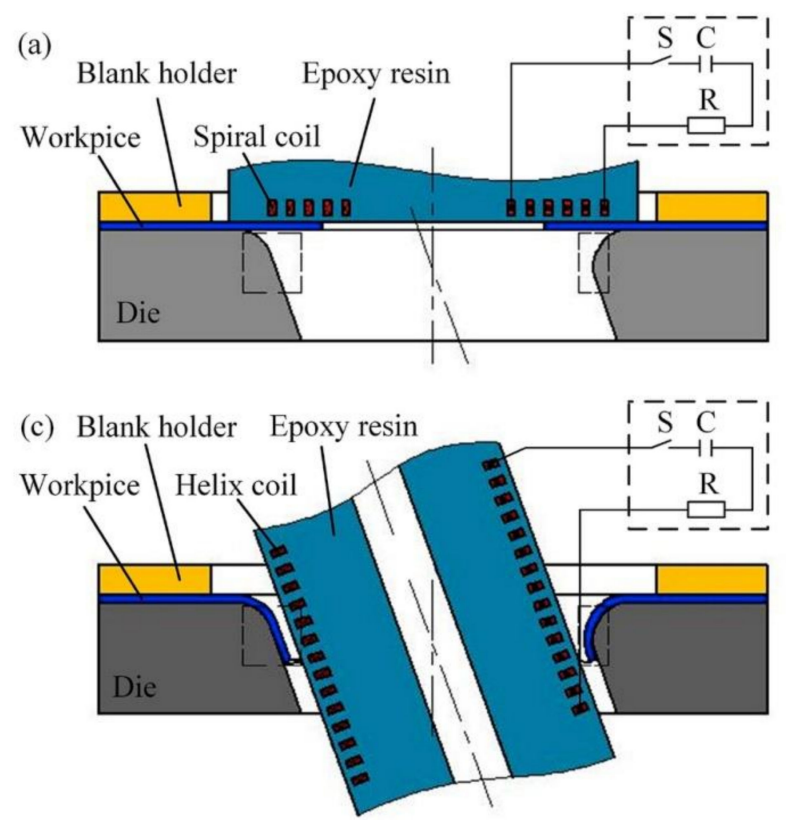

(b)

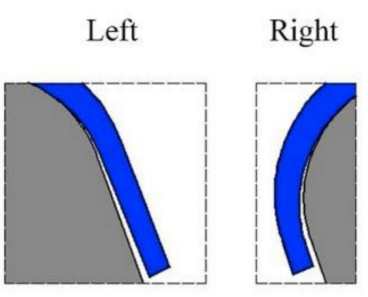

(d)

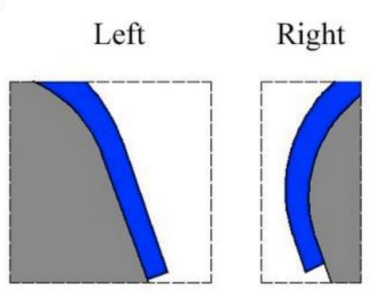

Figure 31. Schematic diagram of a two-step electromagnetic forming (EMF): (a) electromagnetic forming, (b) workpiece after electromagnetic forming, (c) electromagnetic calibration, (d) final part after EM calibration (reproduced with permission from [303]; copyright (C) 2018 Elsevier, Ltd.). 
Similarly, Su et al. [316] studied the uneven deformation behavior of a 2219 aluminum alloy workpiece formed by electromagnetic flanging. The authors established a numerical model (Figure 32) in LS-DYNA 8.0 software to study the effect of different axial angles between the flanging direction and the normal direction of the sheet (Figure 33). They concluded that uneven deformation behavior is essentially due to the uneven deformation requirement. The electro-magnetic force and the area of the deformation region have a significant influence on the uneven deformation behavior. Furthermore, the die constraint indirectly affects the uneven deformation behavior of the sheet metal by changing the evolution of the deformation region. The high-speed electromagnetic impaction behavior according to the Gurson-Tvergaard-Needleman (GTN) model parameters obtained is studied numerically by Feng et al. [317]. The analysis of the void volume fraction and plastic strain distributions are analyzed during the process of high-speed EMF, which indicates the validity of using the GTN damage model to describe or predict the fracture.
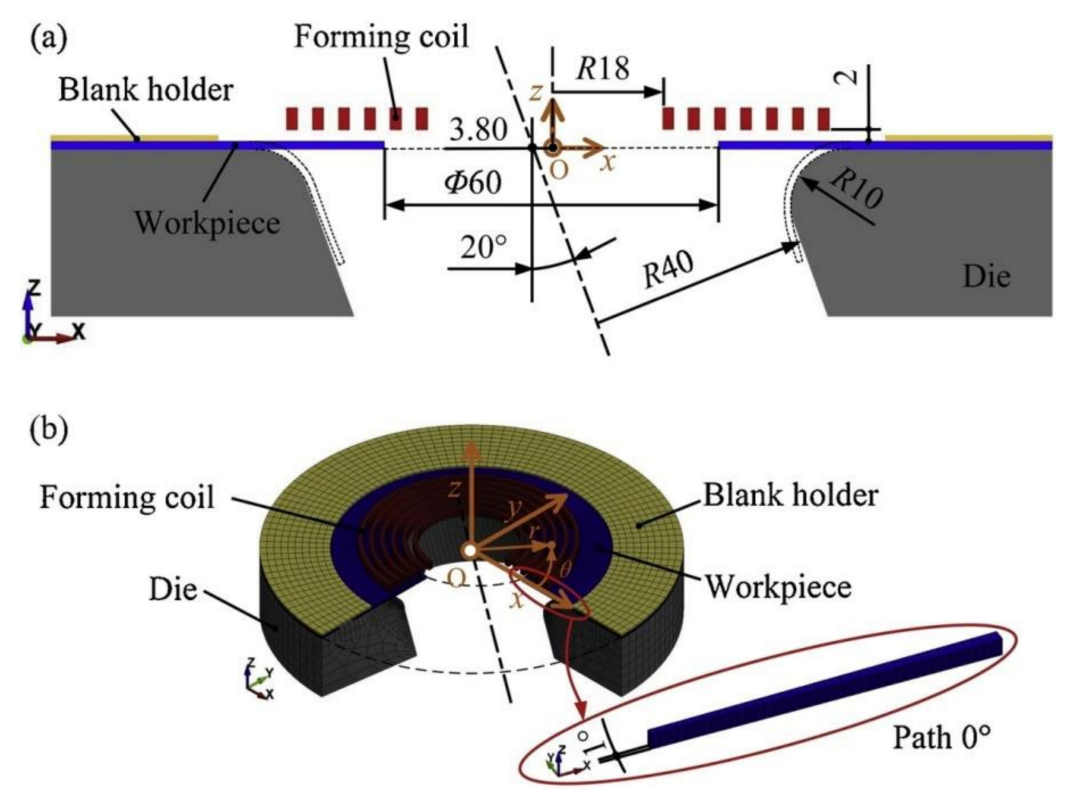

Figure 32. Numerical model of EMF for the hole-flanging process: (a) geometry and dimensions, (b) FE mesh (reproduced with permission from [316]; copyright (C) 2020 The Society of Manufacturing Engineers. Published by Elsevier, Ltd.

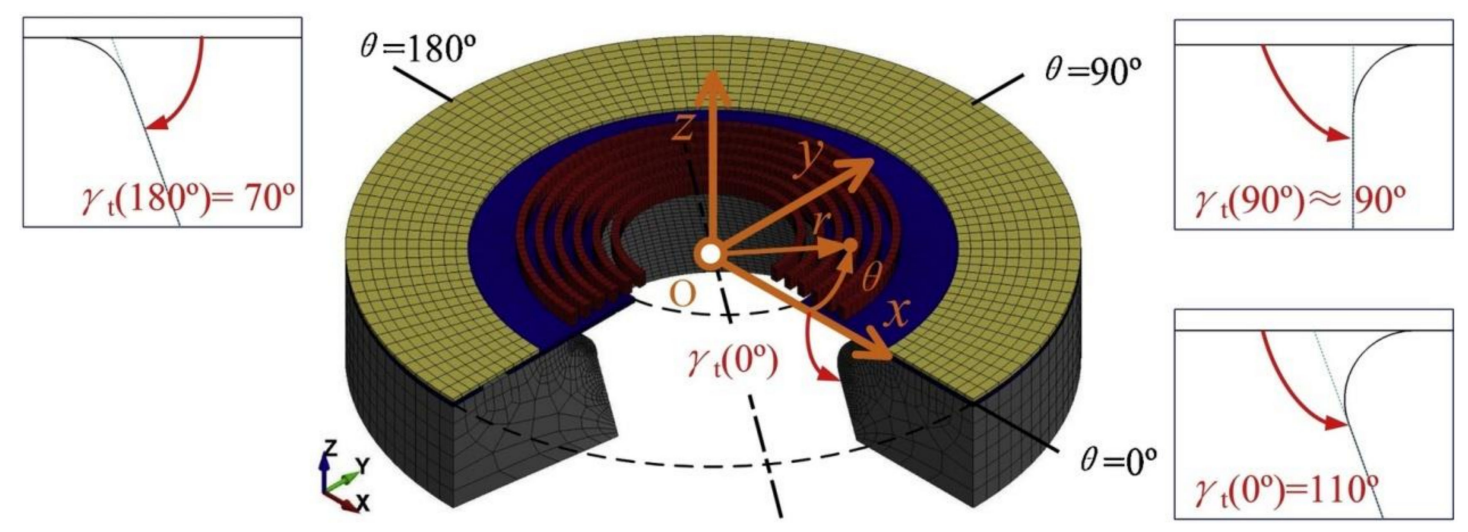

Figure 33. Flanging angles along typical parts (reproduced with permission from [316]; copyright (C) 2020 The Society of Manufacturing Engineers. Published by Elsevier, Ltd.).

Radial Lorentz force augmented deep drawing was developed by Lai et al. [293] to enhance the material flow of the flange in an electromagnetic deep drawing (EMDD) process. This combines an axial Lorentz force on the unsupported region of the sheet metal and an additional radial inward 
Lorentz force at the periphery of the sheet metal. The Lorentz forces are flexibly controlled using a dual-coil electromagnetic forming system (Figure 34). In conventional EMF, there is only one driving coil. Experimental and high-speed multiphysics coupled dynamic numerical contributions on circular aluminum 1060-H24 sheet workpieces permit the draw-in of the flange to linearly increase with the discharge voltage of the axial Lorentz force. Increasing the radial Lorentz driving force leads to an exponential increase of the draw-in of the flange.

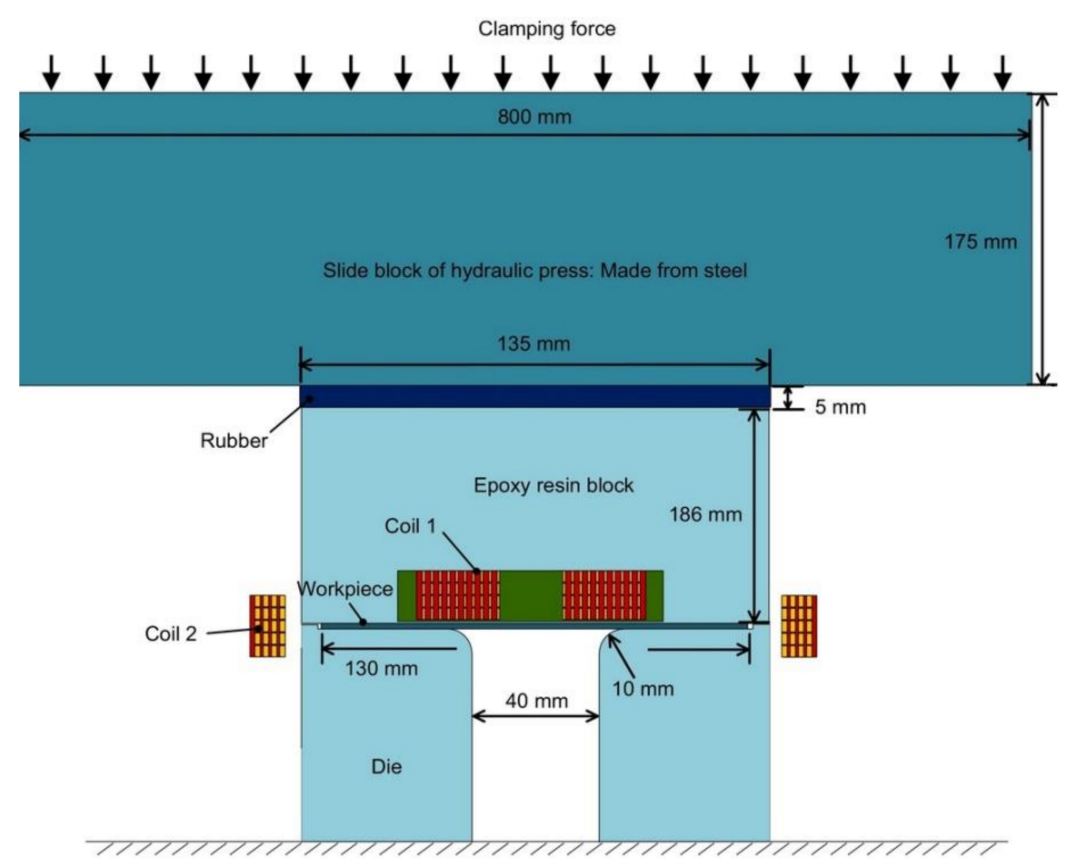

Figure 34. Experimental setup of the electromagnetic deep drawing (EMDD) process (reproduced with permission from [293]; copyright (C) 2017 Elsevier B.V.).

\section{Electrohydraulic Forming}

Advanced high-strength steels and aluminum alloys are among the materials that are currently seeing increased potential application in efforts at weight reduction. A problem common to the use of these materials is their limited formability in SMF operations compared to carbon steels. Electrohydraulic forming (EHF) is able to overcome the limitations of conventional SMF methods [290,318]. In EHF a high pressure, high temperature plasma channel is created between the tips of the electrodes during a high voltage discharge. The electrical energy is stored in a bank of capacitors. The shockwave in the liquid initiated by the expansion of the plasma channel then propagates towards the blank at high speed, and the mass and momentum of the water in the shock wave forms the sheet metal blank into the die [319]. A typical configuration of EHF shown in Figure 35 includes the electrodes, discharge chamber, die, pulse generator (which consists of a high-voltage/high-current discharge switch D), high-voltage low-inductive bank of capacitors $\mathrm{C}$ and a charging/amplifying/rectifying circuit T-R-A. 


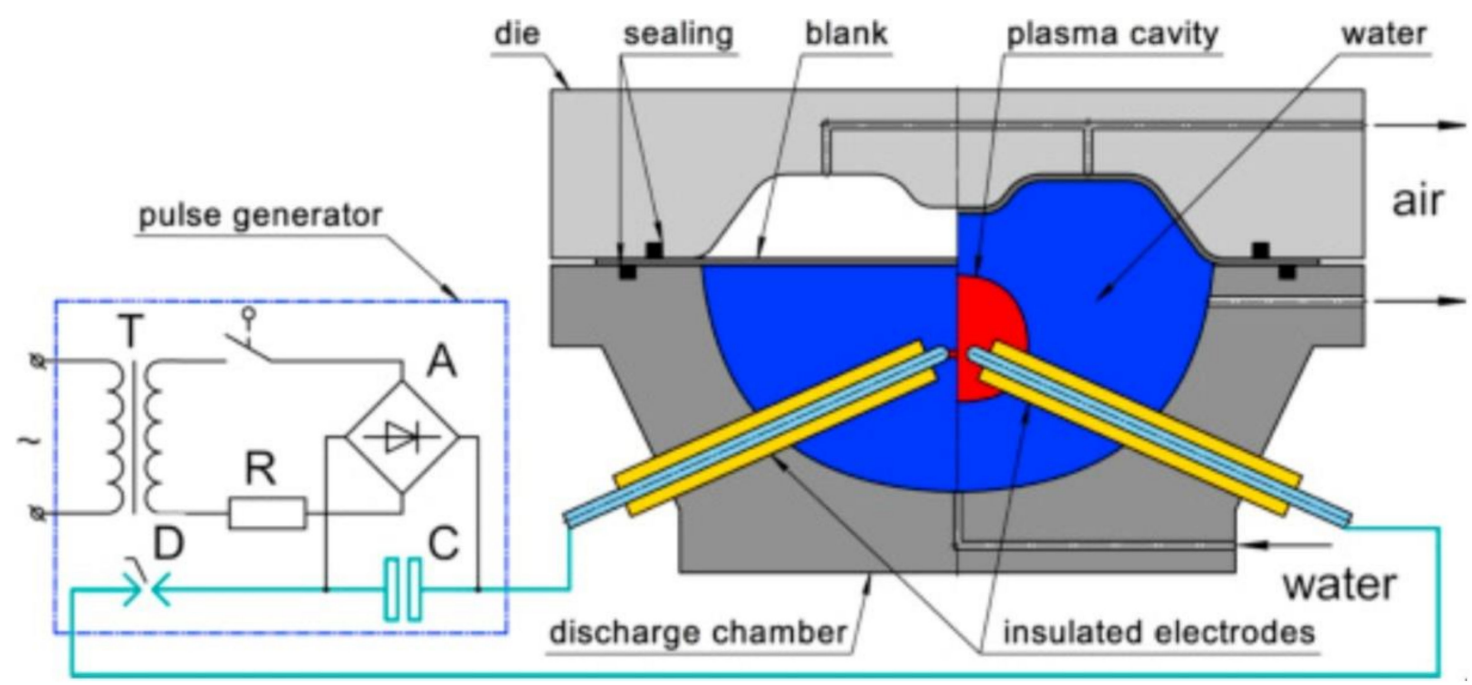

Figure 35. Experimental setup of the EMDD process (reproduced with permission from [319]; copyright (C) 2015 Elsevier B.V.).

Most practical applications of EHF in the last century were related to the aerospace industry, where, typically, rather small parts lying within the overall size range of 300-400 $\mathrm{mm}$ or less were stamped [320]. EHF allows a reduction in capital investment since EHF requires one-sided dies rather than two-sided ones and a reduction in manufacturing costs in the low volume applications of the aerospace industry.

With popularization of the production and applications of high-strength steel sheets, EHF is being taken into consideration as a potential technology for automotive applications [320]. Substantial development of the EHF process includes a durable electrode system, a durable sealing system, an efficient water-air management system and a numerical modeling technique, as reported in [321]. According to Golovashchenko et al. [322], a fundamental advantage of EHF is that it is capable of filling rather complex sheet metal forming shapes in one operation by providing a series of discharges which can fully form the workpiece into the cavity of the stamping die and calibrate springback without opening the chamber and removing water from the tool. The relative improvement in plane strain formability of dual-phase steel in EHF conditions is between $63 \%$ and $190 \%$, compared to the quasi-static limiting dome height test [320]. The high-velocity impact of the sheet against the die in EHF leads to the suppression of void nucleation and a growth in dual phase steels, significantly delaying the onset of failure [323]. Two different strategies of EHF can be distinguished differing in the formability of the sheet material: electrohydraulic free-forming conditions, where the strain rates are rather moderate, and die-forming conditions, where the strain rates are much higher and through-thickness compressive and shear stresses have a significant effect [324].

The formability of the blank material can be significantly improved in the process of warm electrohydraulic forming (WEHF) [325]. The workpiece in hybrid WEHF can be warmed before placing it on the chamber or using an induction coil. According to Figure 36, in order to prevent cooling the blank due to contact between the blank and water, an air gap has been created between the workpiece and water. During the forming of 1000-series aluminum alloy using WEHF at elevated temperatures, a 23.6\% increase in failure strain is observed at WEHF when compared to EHF (Figure 37) [325]. 


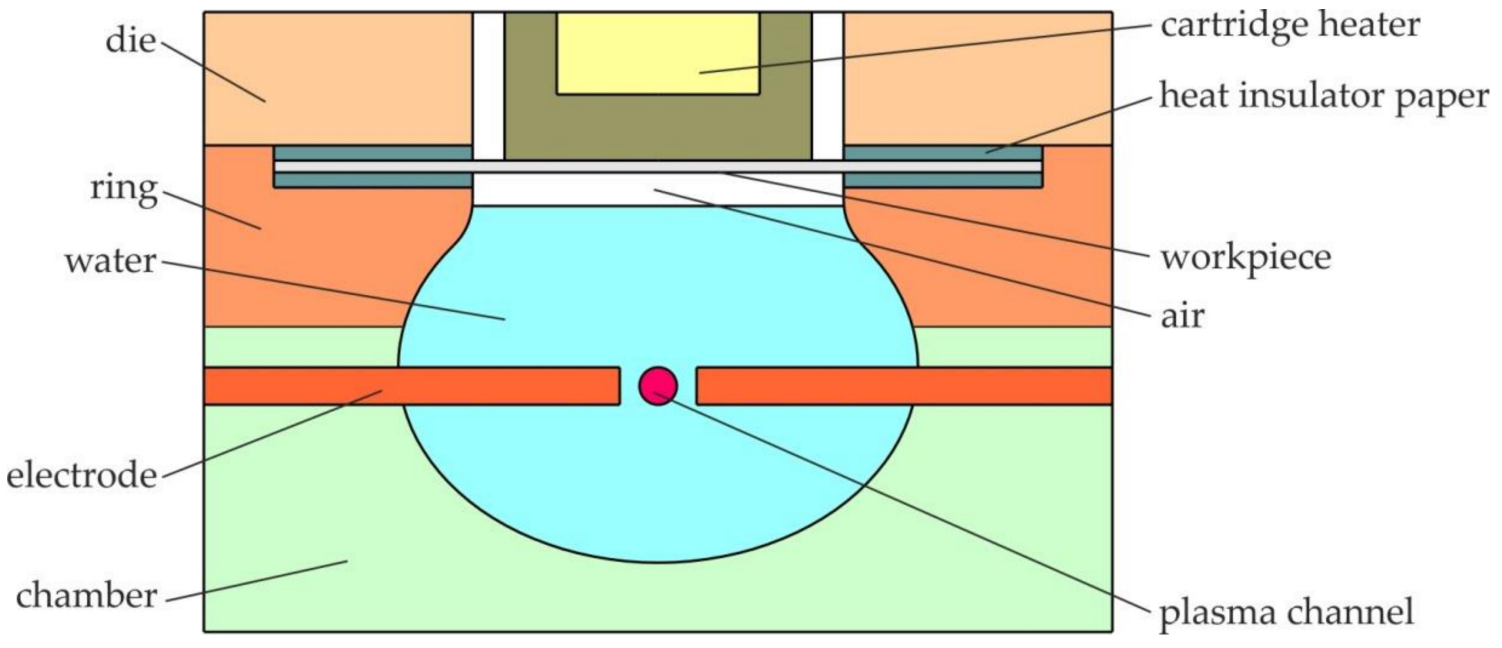

Figure 36. Schematic diagram of the cross-section of warm electrohydraulic forming (WEHF).

$\mathrm{T}=110^{\circ} \mathbf{c}$

Room Temperature

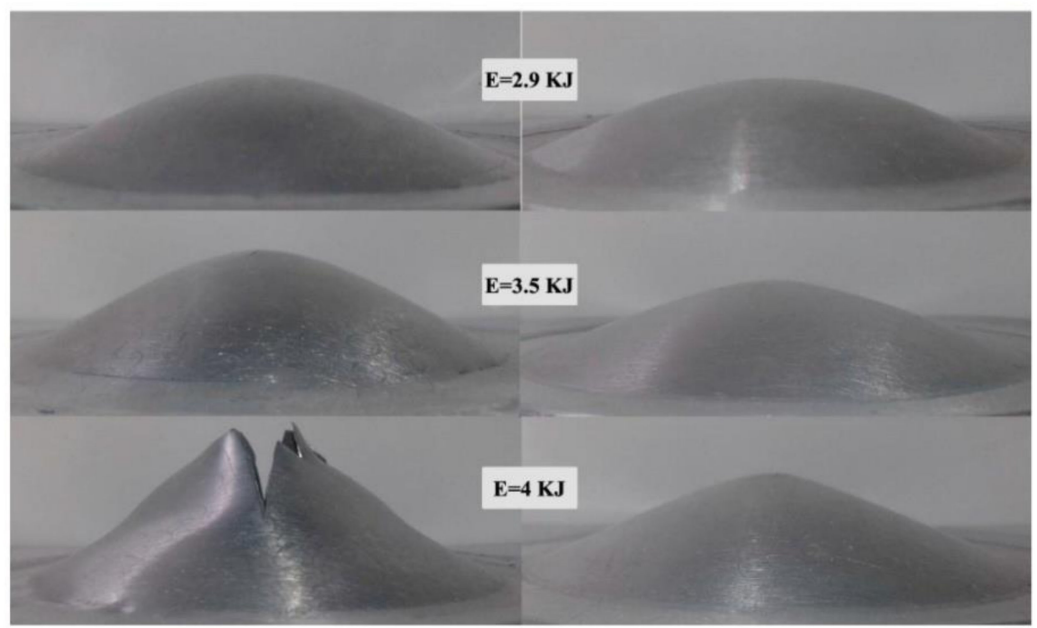

Figure 37. Comparison of the final shapes of specimens formed at $110^{\circ} \mathrm{C}$ and $27^{\circ} \mathrm{C}$ using different energies E (reproduced with permission from [325]; copyright (C) 2017 the authors. Published by Elsevier, Ltd.).

\section{Spinning and Shear Spinning}

\subsection{Background}

Spinning is the shaping of a rotating disc or drawpiece by applying local pressure using a spinning tool (Figure 38). A forming tool, in the form of a mandrel or a roll, can roll or slide over the surface of the sheet. A characteristic feature of the spinning process is that the thickness of the sheet metal, from which the element is formed, changes within only a very small range. The deformed disc or blank gradually adopts the shape of the spinning block, which is usually made of metal. In the case of spinning components with complex shapes, partial or uniform spinning blocks are used. The spinning tool and workpiece performs a rotational motion. Spinning ability is measured by the limiting spinning ratio, which is the ratio of the maximum original blank diameter that can be successfully spun forming a cup, in a single pass, to the mandrel diameter [326-330].

The classification of traditional spinning processes has mainly been developed according to the relative position between the roller and the blank, the deformation characteristics of the blank material, 
the temperature of the blank, as well as spinning with or without a mandrel [331-333]. The classification of the traditional spinning processes is presented in Figure 39.

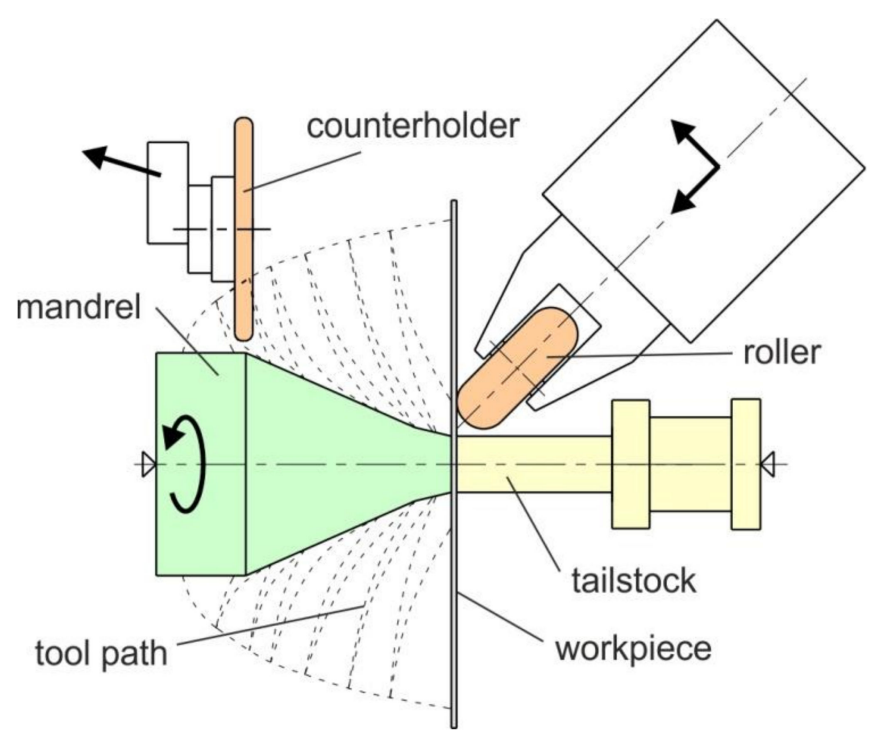

Figure 38. Schematic illustration of conventional sheet metal spinning.

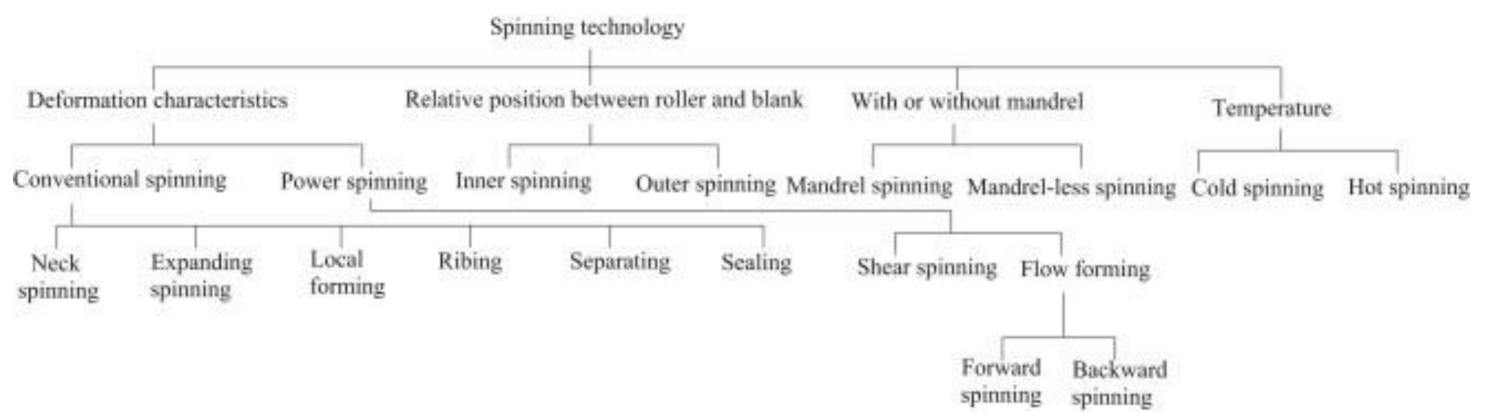

Figure 39. Classification of the conventional spinning process (reproduced with permission from [330]; copyright (C) 2014 Elsevier, Ltd.).

Shear spinning is the process combining conventional spinning with simultaneous intensive thinning of the wall. Shear spinning is applied to discs or drawpieces from which cylindrical, conical or curvilinear shapes with a thick bottom and thin walls are obtained. Unit pressures in shear spinning processes reach $3000 \mathrm{MPa}$. The process parameters, i.e., circumferential speed, reaching up to $5 \mathrm{~m} \cdot \mathrm{s}^{-1}$ and a feed rate in the range of $0.01-0.25 \mathrm{~mm}$ per revolution, are assumed. The finished component formed by shear spinning is characterized by a very smooth surface and increased mechanical properties due to the work hardening phenomenon.

Flow forming, also known as tube spinning, is one of the techniques closely allied to shear forming [334,335]. In this process (Figure 40), the sheet metal is displaced axially along a mandrel, while the internal diameter remains constant. Flow forming is usually employed to produce cylindrical components [332,336]. There are many varieties of flow forming methods with regard to tool design. Most modern flow forming machines employ two or three rollers and their design and structural strength is more complex than that of spinning and shear forming machines. Using spinning methods, it is possible to produce axisymmetric and asymmetric components with complex shapes, a task which is difficult or sometimes even impossible by conventional stamping methods. Spinning methods are used in particular for difficult-to-form alloys [334,337]. 


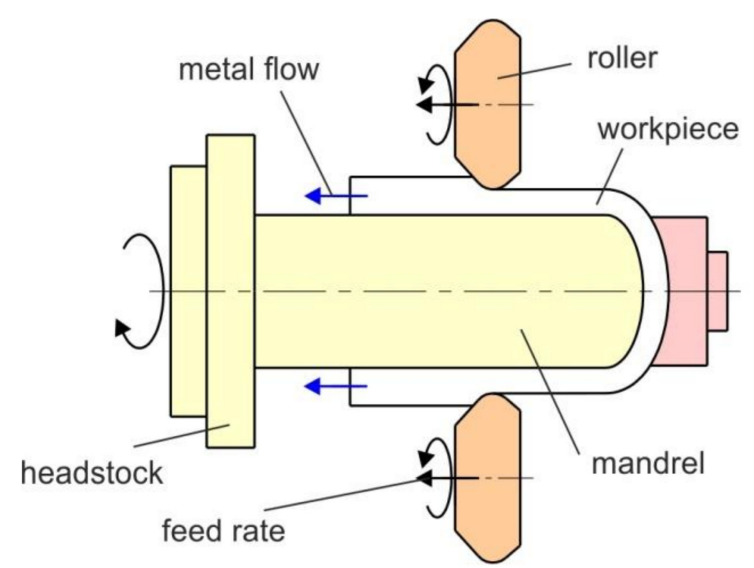

(a)

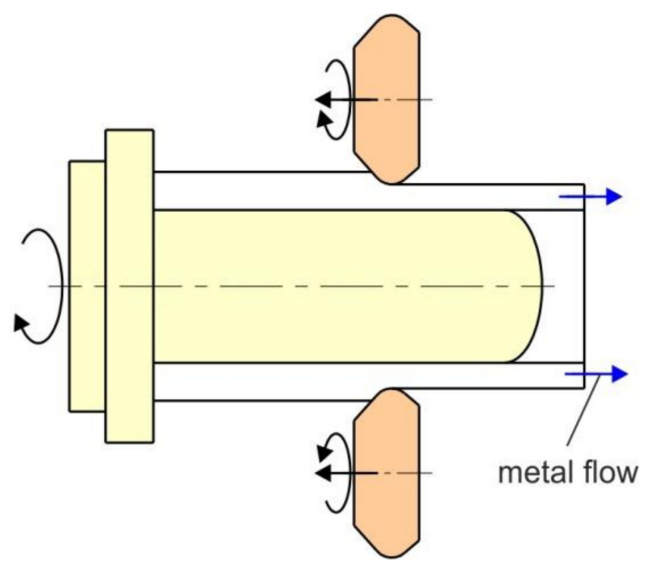

(b)

Figure 40. (a) forward and (b) backward flow forming.

\subsection{Conventional Axisymmetrical Spinning}

The most challenging aspect in this process is the low formability of the workpiece material due to the formation of wrinkling in the free flange [326]. Several attempts have been made to study the spinning process, particularly the thickness, geometry and profiles of the final component, failure modes and material formability [338-341]. The most important parameters affecting wrinkling are, large mandrel diameter, small modulus of plastic buckling and small thickness of the original blank [342-345]. In addition, several studies [346-348] have shown that spinning of thicker sheet metals will fail due to the formation of wrinkling in the unsupported part of the blank at higher roller feeds [327,347,349]. The tendency for wrinkling to occur increases significantly with higher roller angles and higher roller feeds. In the case of the deep spinning process, the formation of wrinkling can be limited by a roller aided by a constant clearance blank holder (Figure 41). Experimental investigations when forming commercially pure aluminum A199.5 sheets confirm the ability of the proposed tool to suppress wrinkling in order to improve spinning formability [326]. Based on overcoming fracture failure and wrinkling, many attempts have also investigated using conical, flat conical or D-shaped rollers [327] with various working conditions to enhance spinning formability.

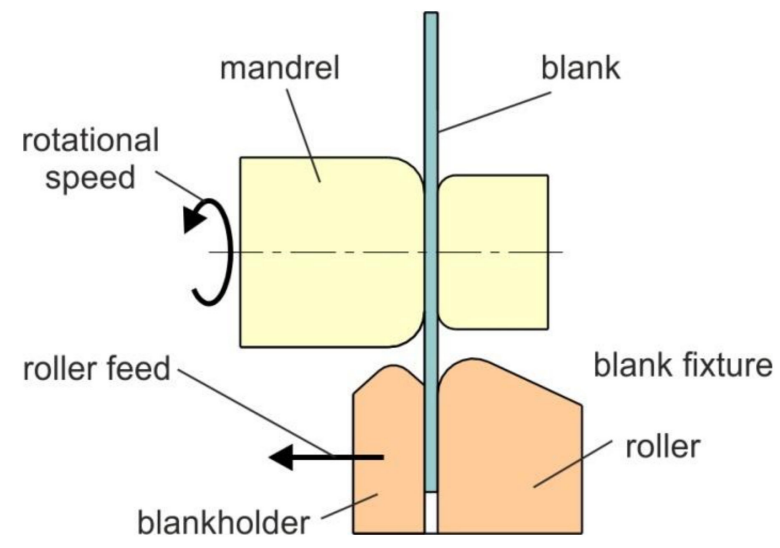

Figure 41. Schematic diagram of deep spinning.

Using the spinning process to produce axisymmetric parts produces a thinner cup wall with smaller roller nose radii, smaller roller feeds and higher roller angles. The inner profile of the final spun cup is larger than the mandrel profile due to springback [350]. The springback phenomenon is more visible with smaller roller nose radii, higher conical roller angles and higher roller feeds. Automation of the spinning process requires techniques to predict workpiece failure based on the path of the tool. 
Analytical methods to predict workpiece failure are of practical use for online correction of the tool path. Therefore, Russo et al. [351] proposed a method in which a haptic device is connected to a computer numerical control (CNC) spinning machine; this device allows a human operator to control the working roller manually while feeling the force applied to the workpiece. Haptic devices provide users with force feedback and have found applications in gaming and robotic surgery [332,352]. A control system consisting of force, position and workpiece shape sensors allows the collection of information on the tool path followed by the operator and on its effect on the mechanics of the forming process.

\subsection{Asymmetric Spinning}

The challenge of extending the conventional spinning processes to other areas of application has given rise to investigation of the fabrication of non-axisymmetric parts. Four approaches to this have been identified; using a radially offset mandrel, using spring-controlled rollers, using a feedback control system and using a radially offset roller (Figure 42).

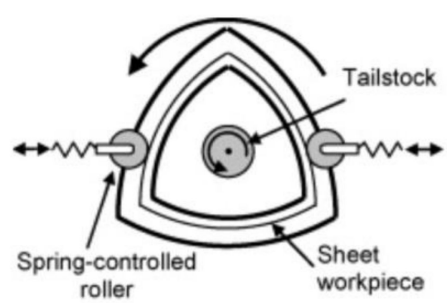

(a) Spring-controlled rollers

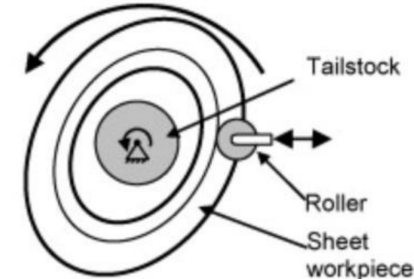

(b) Radially offset roller

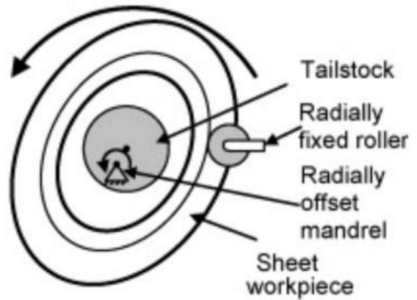

(c) Radially offset mandrel

Figure 42. Schematic diagram of asymmetric spinning: (a) spring-controlled rollers, (b) radially offset roller, (c) radially offset mandrell (reproduced with permission from [333]; copyright (C) 2010 Elsevier B.V.).

To overcome the limitations of ordinary asymmetric spinning, Shimizu [339] developed a machine (Figure 43) for the synchronous spinning of asymmetric truncated cone-shaped components. In this case, the mandrel feed, roller feed and mandrel motion were synchronized by pulse control. The successful application of the proposed method for the formation of a truncated pyramid-shaped product with a sidewall and an asymmetric truncated, elliptical, cone-shaped product confirmed the flexibility of this method.

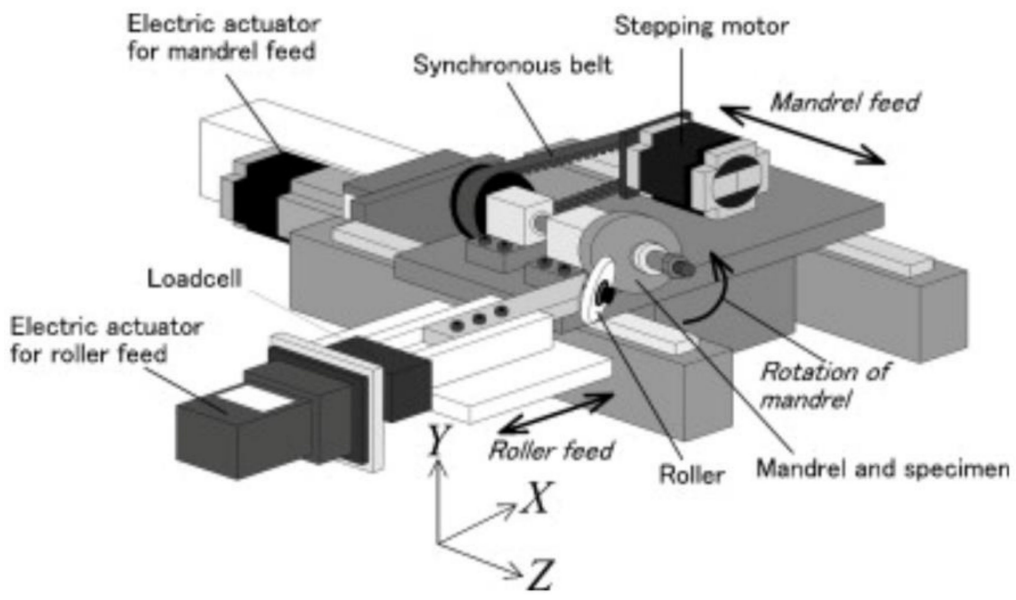

Figure 43. Schematic diagram of asymmetric spinning (reproduced with permission from [339]; copyright (C) 2010 Elsevier B.V.).

Methods to design the multipass tool paths and blanks required for the spinning of both asymmetric and axisymmetric components without a mandrel were investigated by Russo et al. [353]. They applied 
the flexible spinning method (Figure 44) developed by Music and Allwood [354]. The results show that increasing the degree of asymmetry of the target part only weakly influences the forming weight achievable in mandrel-free spinning. This method is seen as having great potential to fabricate multiple geometries flexibly and to reduce the costs of prototyping considerably.
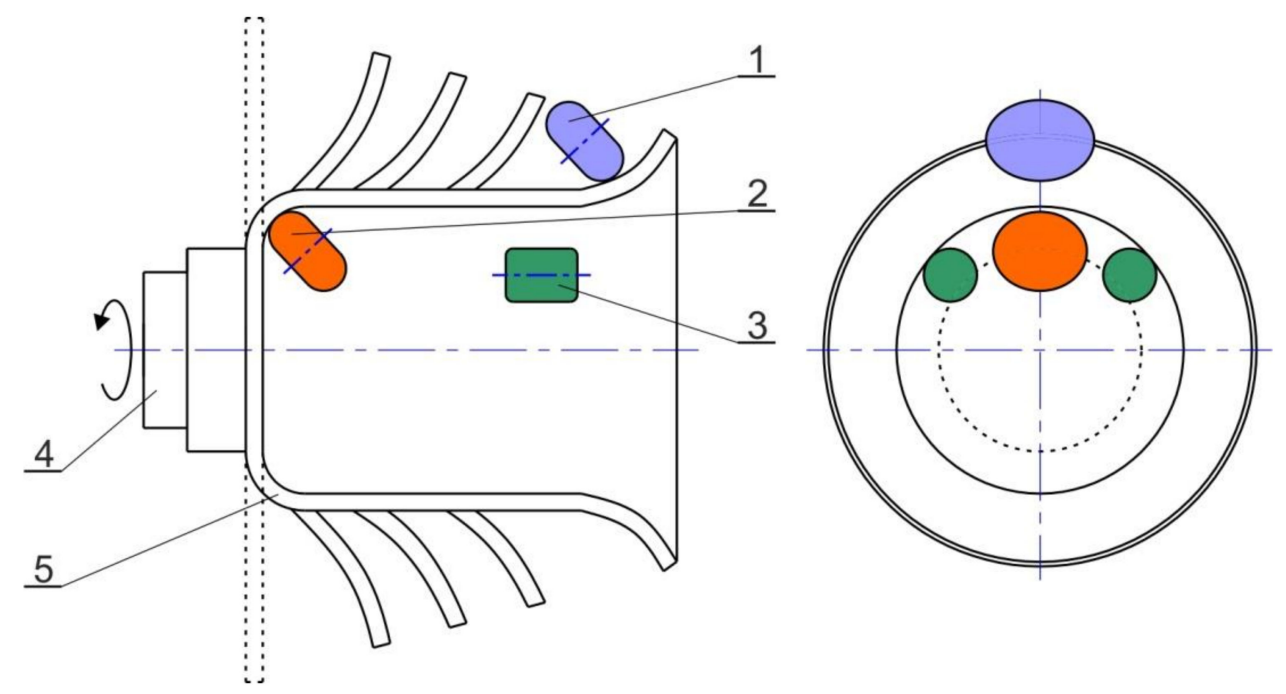

Figure 44. Schematic diagram of asymmetric spinning: 1-working roller, 2-blending roller, 3-support roller, 4-tailstock, 5-workpiece.

Sugita and Arai [342] were the first to perform multipass spinning on a part with asymmetric vertical walls in a rectangular box (Figure 45a). They designed a synchronous multipass spinning machine (Figure $45 \mathrm{~b}$ ) which could apply to both axisymmetric and asymmetric cups. Their setup employed a mandrel. They found that a lower height could be achieved in an asymmetric component than in an axisymmetric one. Arai [355] applied a hybrid force/position control system to allow the roller to track an asymmetric mandrel. This approach has been successfully applied to form asymmetric drawpieces in shear spinning.

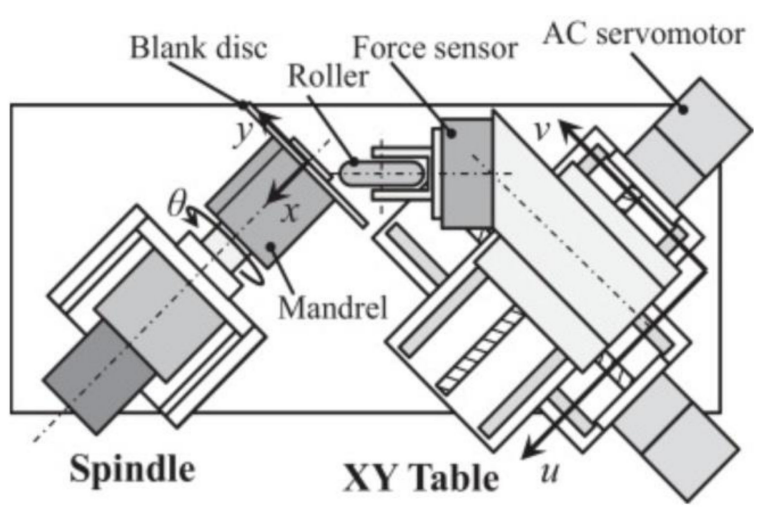

(a)

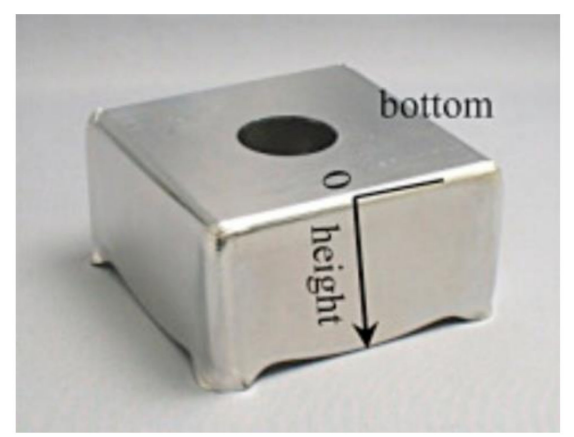

(b)

Figure 45. (a) Synchronous multipass spinning machine and (b) an example of the rectangular box shape formed using rotational pass (reproduced with permission from [342]; copyright (C) 2015 Elsevier B.V.).

\subsection{Heat-Assisted Spinning}

In conventional spinning processes, the forming limit of the workpiece material is restricted due to the work hardening effect [356]. An effective approach to improve the forming limits is the use of heat treatment which can be achieved by intermediate heating, burner systems or the use of lasers (Figure 46) $[333,357]$. These approaches worsen the process flexibility by increasing the 
costs associated with energy and maintenance. The main benefits of laser-assisted metal spinning operations are: (i) improved reproducibility when compared to gas burners, (ii) improved formability of challenging materials such as nickel-based alloys [334,358,359], magnesium alloys [360,361] and titanium alloys [362-364], (iii) reduced forming forces and (iv) improved component quality due to locally limited heating. In their study, Nguyen-Tran et al. [365] summarize the previously reported electroplastic behavior of various metals or metal alloys and recent electrically assisted manufacturing processes.

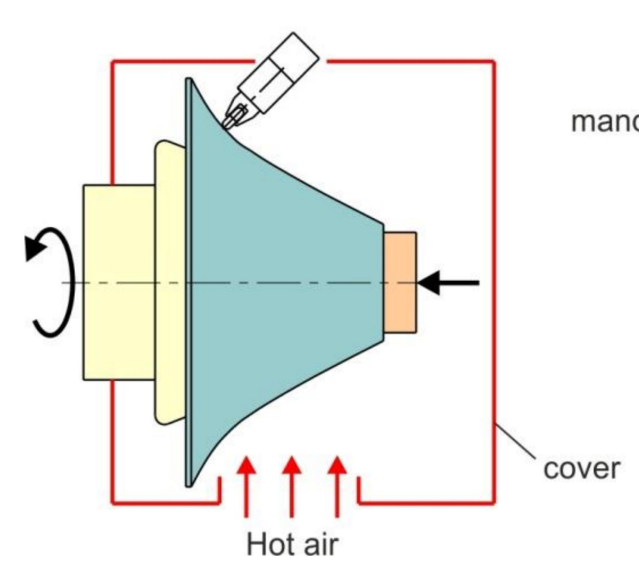

(a)

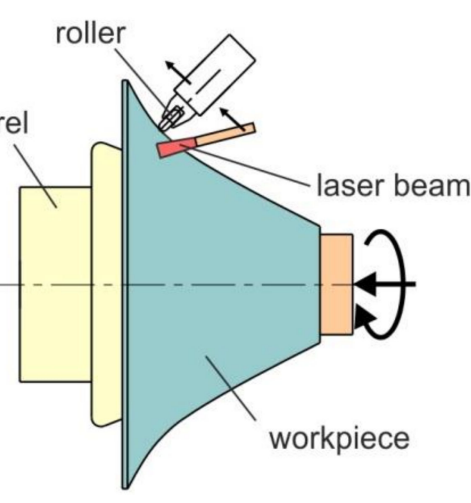

(b)

Figure 46. Hot spinning with (a) hot air and (b) laser.

Another approach is to use the friction-spinning process (Figure 47). As a consequence of a localized warm-forming operation, multifunctional components can be manufactured with locally varying mechanical properties that satisfy the demands of lightweight design. Figure 48 shows the forming strategies in conventional and heat assisted spinning. The conventional spinning process is characterized by the use of additional equipment and complex tool path geometries. If an additional reduction in wall thickness of the drawpiece side wall is required, it is necessary to use a multipass strategy. Furthermore, it is possible to achieve a defined adjustment of the hardness distribution by varying the parameters. The possibility of extending the forming limits of conventional spinning through in-process heat generation is confirmed by Lossen and Homberg [356].
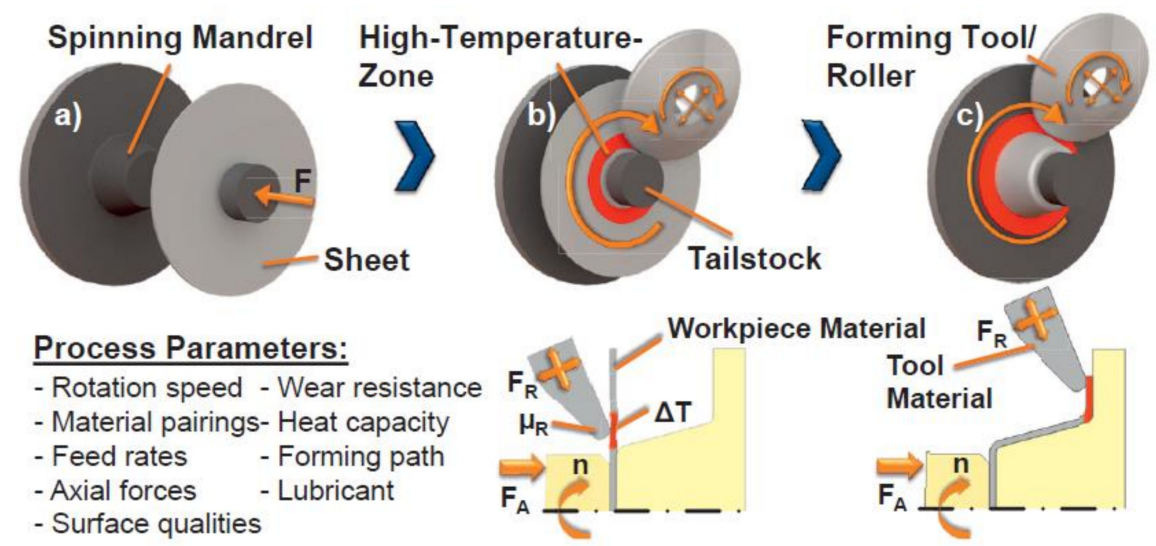

Figure 47. Friction-assisted spinning (reproduced with permission from [356]; copyright (C) 2014 the author(s). Published by Elsevier, Ltd.). 


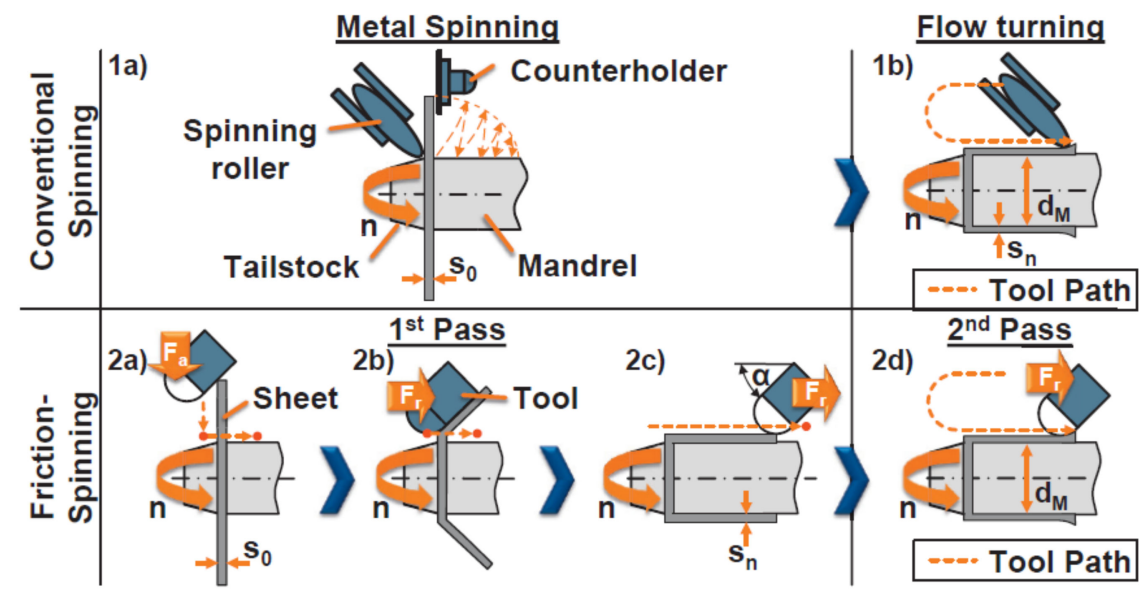

Figure 48. Comparison of the principles of cup forming by friction-assisted spinning and conventional spinning with one-pass and two-pass forming strategies (reproduced with permission from [356]; copyright (C) 2014 the author(s). Published by Elsevier, Ltd.).

Homberg et al. [366] used frictional heat between the workpiece and friction tool/roller (Figure 49) to increase workpiece temperature. In the process a workpiece is set in rotation in a conventional spinning machine while a pressure or friction plate works in an axial direction on the material to be deformed. The combination of spinning with friction-induced heat makes it possible to achieve a larger deformation to deform tailor-made components which are functionally graded and to produce a workpiece with more complex geometry [367]. Therefore, the use of frictional heat may provide a potential heating method which can be widely applied in the hot spinning process.

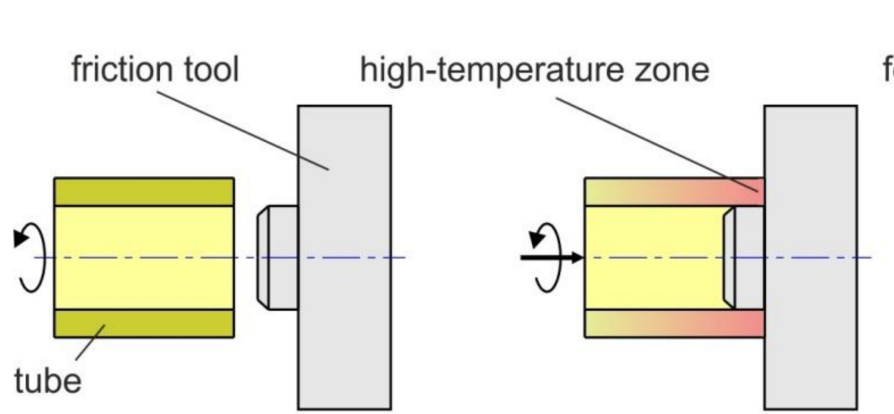

(a) (b)

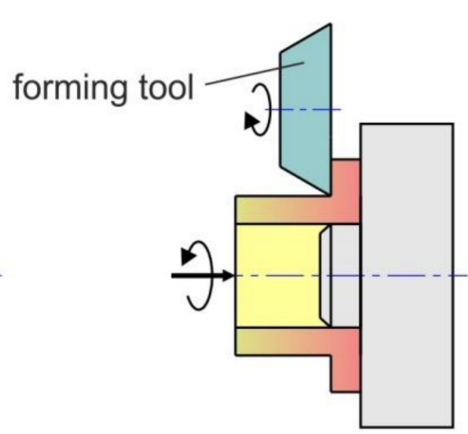

(c)

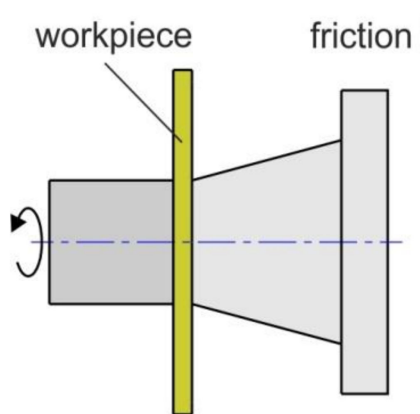

(d)

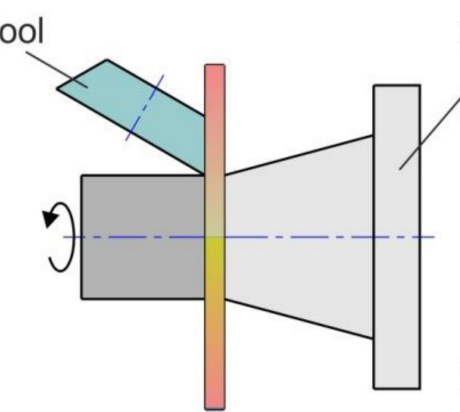

(e)

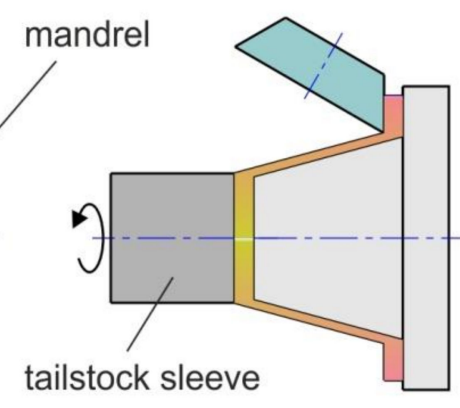

(f)

Figure 49. (a-f) Sequential stages of friction spinning.

In recent years, the demands on lightweight construction with respect to its functional qualities and potential to save resources by reducing weight have increased significantly. Tailor-made components with functionally graded properties manufactured by a novel so-called friction-spinning process meet 
these demands very well. This new process combines elements from metal spinning and friction welding to a new thermomechanical process for the manufacture of complex hollow parts made of tubes, profiles or sheet metals.

\subsection{Shear Spinning and Flow Forming}

In shear spinning forming, a sheet blank is formed by a roller into an axisymmetric part with a desired shape and thickness distribution. The thickness is deliberately reduced to obtain the desired distribution. Due to the localized deformation of the material, shear spinning has major advantages, such as high utilization of the material, simple tooling and low forming force. The work hardening phenomenon improves the mechanical properties of spun components. Hence, this often eliminates the requirement for any additional heat treatment to be carried out on finished parts $[368,369]$. Shear spinning is widely used to manufacture components in the aerospace, weapon, aviation and automotive industries $[330,332,333]$. Materials that are difficult to deform at room temperature, such as titanium alloys [370,371], nickel-based alloys [357,372] and stainless steel [373], are commonly deformed using the shear spinning process.

Dieless shear spinning (DLSS), as a kind of conventional shear spinning, can form many types of product using only an elastic multipurpose base instead of a mandrel [124,374]. At first, a blank sheet is laid over an elastomer base and is rotated on a lathe (Figure 50). Then a bulged circle is formed on it like a ring doughnut when the hemisphere tip of the bar tool is pressed on it. The component is completed when its wall height is increased by repetition of piling up the traveled steps [124]. DLSS is considered an innovative method since it is possible to form components with a vertical wall. DLSS is found to be an effective way of forming the skin of the air intake lip of airplane jet engine nacelles [375].

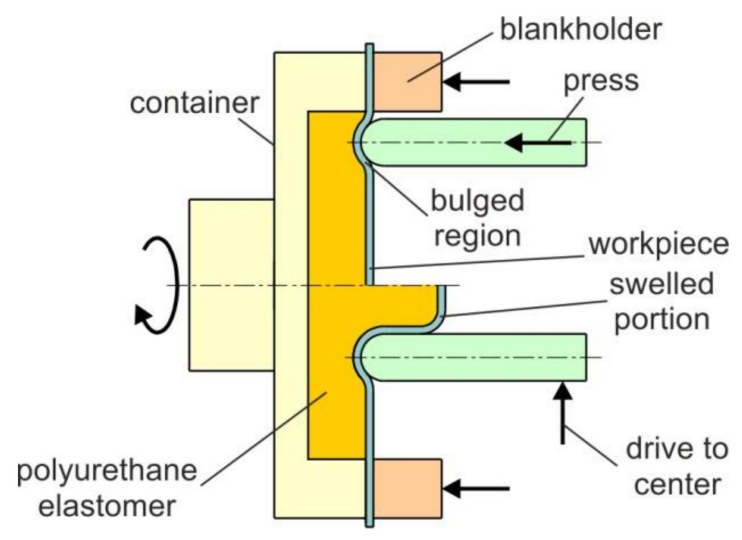

Figure 50. Dieless shear spinning.

In double-sheet dieless shear spinning, two aluminum disk blanks arranged concentrically are formed into a truncated cone. The cover thicknesses of the spun workpieces are smaller than the value that conforms to the sine law using the same blank thickness. The wall thicknesses of the base spun workpieces are greater than the sine law value under the same circumstances. The theoretical mechanics analysis of the double-sheet shear spinning process is carried out through mechanics and finite element analysis. Jia et al. [376] analyzed the mechanics of double-sheet dieless shear spinning (Figure 51). In a double-sheet DLSS the roller path coincides with that of traditional shear spinning. It is predicted that the wall thickness distribution can be different from the sine law while retaining the same shape of the lower workpiece with the single-sheet working condition. 


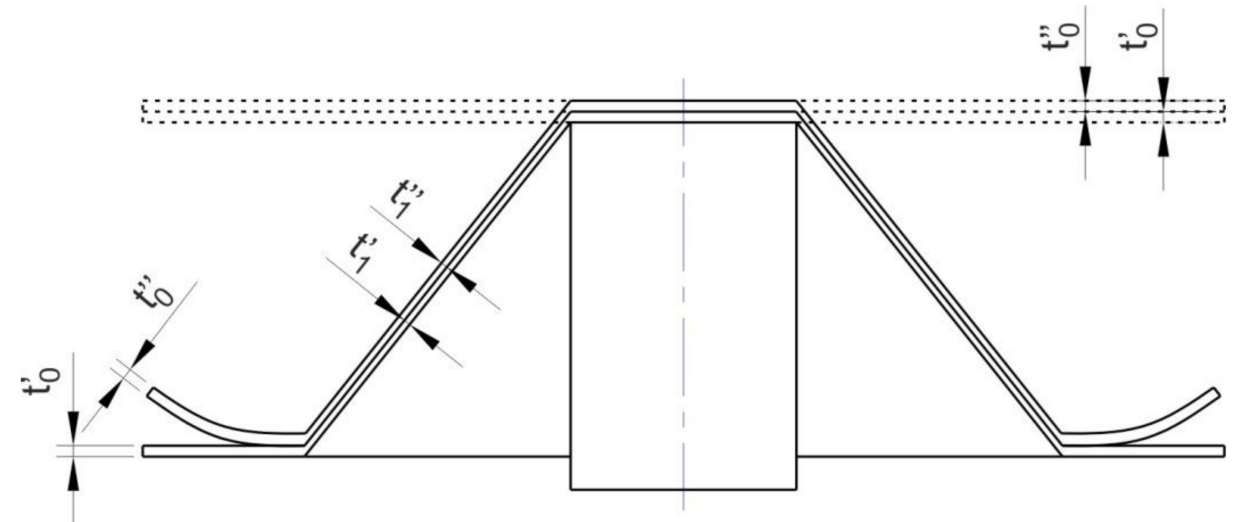

Figure 51. Schematic diagram of double-sheet shear spinning.

Han et al. [370] proposed innovative flame-heating integration into a spinning machine to apply new processing strategies for flame-assisted dieless shear and multipass metal spinning. The results of forming pure titanium TA2 and its alloy TC4 plates show that the forming accuracy is acceptable when adopting the system under two forming temperatures, $450{ }^{\circ} \mathrm{C}$ and $850{ }^{\circ} \mathrm{C}$. In double-sheet dieless shear spinning, two aluminum disk blanks arranged concentrically are formed for a truncated cone. The cover thicknesses of the spun workpieces are smaller than the value that conforms to the sine law using the same blank thickness. The wall thicknesses of base spun workpieces are greater than the sine law value under the same circumstances.

Flow forming (Figure 52) is one of the incremental bulk-metal-forming processes, used for the manufacture of tubular parts [377]. Flow-forming was used to process a wide range of materials [378,379]: Inconel, Hastelloy, titanium, maraging steels, stainless steels and precipitated hardened stainless steels [167]. Multipass tube spinning at elevated temperature is generally applied when processing titanium parts due to its advantages of simple tooling, low forming force and high material utilization [332,377,380,381]. Later research is focused more on the analysis of different kinematic and dynamic characteristics of the flow forming process and assurances of geometric accuracy of the formed components. Sivanandini et al. [378] have shown potential applications of the flow forming method in automotive, defense and aerospace applications.
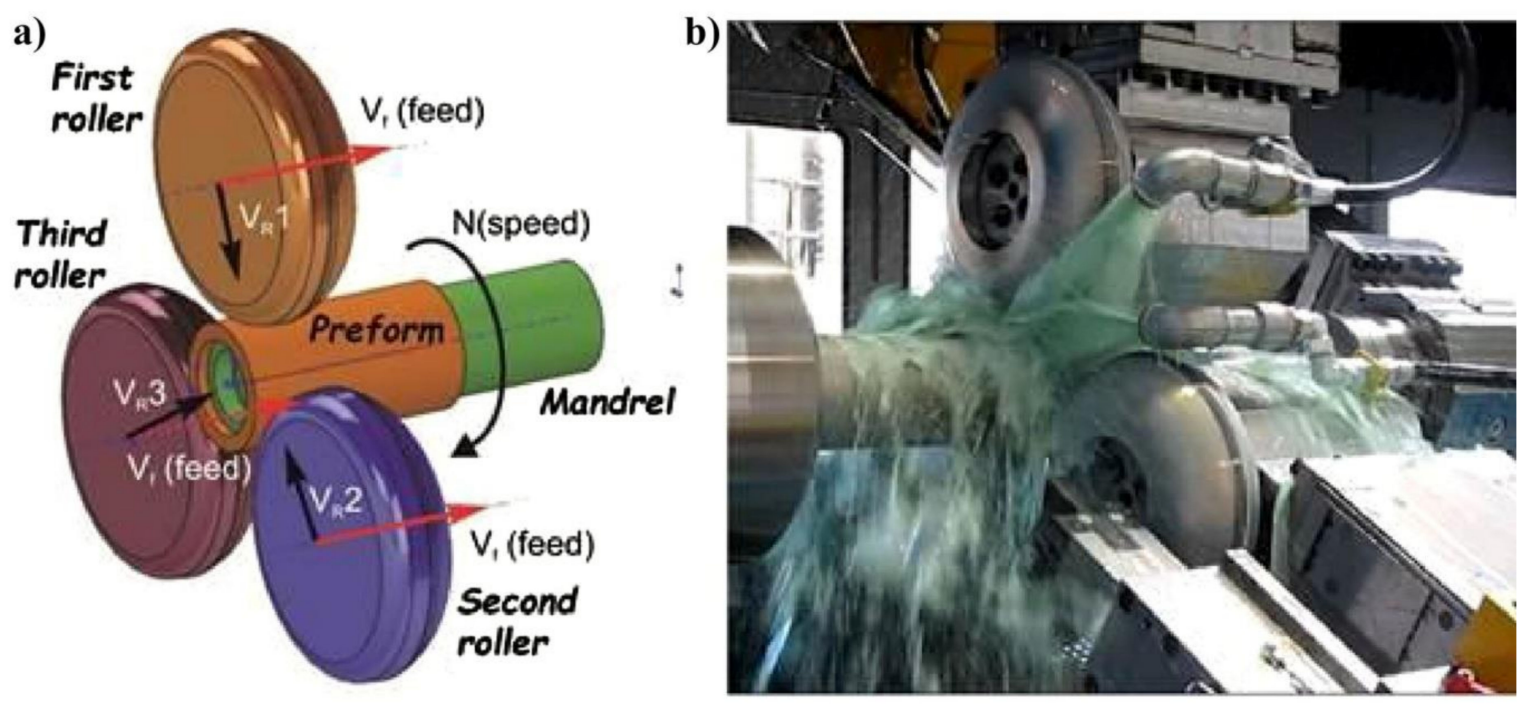

Figure 52. (a) schematic diagram of flow forming and (b) the flow forming machine (reproduced with permission from [377]; copyright (C) 2018 Elsevier B.V.). 


\section{Conclusions}

This study gives an overview of the main topics concerning the development of sheet metal forming methods including spinning and shear spinning, flow forming, incremental sheet forming including water jet sheet forming, flexible-die forming, multipoint die forming, solid granular medium forming, electromagnetic and electrohydraulic forming. The progress observed in the last decade in the area of SMF concerns mainly the development of nonconventional methods of forming difficult-to-form lightweight materials for automotive and aircraft applications. The most important trends in the development of modern machines include the improvement of their design to increase their performance with significant production flexibility, reducing production costs and the development of structures adapted to unconventional methods of plastic forming. To state the major achievements in the previous sections, the following conclusions are highlighted:

- Friction and lubrication are key factors in sheet metal forming which decide product quality and productivity as well as the environmental performance of manufacturing. The main problems observed in SMF concern processes carried out at elevated temperatures where high levels of friction and wear occur due to high adhesion between the tool surface and the workpiece and surface fatigue is then initiated. National and international regulations have meant that the use of environmentally friendly lubricants has become increasing important. At the same time friction conditions have to be minimized in order to reduce loads. An example of environmentally friendly technology is hydroforming, which eliminates metallic contact of the forming tool with the workpiece. Thus, friction forces and tool wear are eliminated. In evaluating the ecological convenience of SMF processes the tribological aspects will receive great attention in the near future.

- In new vehicle development, weight reduction is one of the most important driving forces. The main trend involved in producing lightweight automotive structures with low cost manufacturing and reduced vehicle weight is the use of advanced high-strength steels and aluminum alloys with very high strength and good formability. However, some manufacturing problems related to residual stresses and springback must be overcome. Nonconventional forming techniques (i.e., electromagnetic or electrohydraulic forming, solid granular medium forming) with high deformation rates cover these requirements. Hot forming utilizing the advantageous effect of higher temperatures on the improvement of formability should be also mentioned. The advantage of hydroforming is that it shapes the product in one operation, which speeds up the production cycle and eliminates the need for interoperational storage.

- The utilization of conventional forming is more time-consuming and costly for processes recently applied in the production of parts in small batch production. Consequently, there is a need to disseminate an alternative process to reduce the manufacturing costs and time while forming individual parts, like medical implants. Processes which show benefits in this respect are methods of incremental sheet forming which do not require the manufacture of dies for operation and have the ability to shape elements on a conventional CNC milling machine. The problems related to material springback may be effectively reduced by rapid change of the forming strategy and tool path.

- The increasing complexity of components formed by SMF techniques as well as the continuous extension of the process window have made it necessary to develop new methods to efficiently analyze the forming strategies. Current numerical analysis software offers the capability of designing the tooling and process parameters in a virtual environment. Application of general purpose FEM, DEM, ALE and CFD codes may be regarded as one of the possible routes in the simulation of sheet metal forming. The use of simulation programs requires a thorough knowledge of continuum mechanics and FE programming to develop a suitable numerical analysis for a forming process. In the future, most experimental and numerical research work must be focused on the development of a macroscopic constitutive model based on a physical mechanism, 
grain-twinning interactions and a crystal plasticity model considering the grain-grain interaction and new constitutive models to establish the material behavior of new multifunctional materials.

- The goal of the designers of modern machines and instrumentation for SMF is to ensure that the product can be manufactured in one work cycle and on one machine. The development of machine tool design for plastic working is focused on improving the quality of the product and increasing productivity while maintaining the economic aspects of the manufacturing process. Progress in the implementation of automatic control systems and product manipulation during and after machining is clearly visible in the area of plastic forming processes. Despite the constant tendency to reduce the size of the production series related to the short-term launching of new series of vehicles, it should be hoped that the demand of the automotive and aviation industries for innovative technologies will translate into a greater interest in metal forming technologies. In this manufacturing area, all the considerations given in the previous section should be analyzed taking into account the sustainable break-even point. The development of innovative SMF processes will depend upon the improvement of materials and require adaptive control systems and integrated design of the forming process equipment and tooling.

Funding: This research received no external funding.

Conflicts of Interest: The author declares no conflict of interest.

\section{References}

1. Hagenah, H.; Schulte, R.; Vogel, M.; Hermann, J.; Scharrer, H.; Lechner, M.; Merklein, M. 4.0 in metal forming - questions and challenges. Procedia CIRP 2019, 79, 649-654. [CrossRef]

2. Gronostajski, Z.; Pater, Z.; Madej, L.; Gontarz, A.; Lisiecki, L.; Lukaszek-Solek, A.; Luksza, J.; Mróz, S.; Muskalski, Z.; Muzykiewicz, W.; et al. Recent development trends in metal forming. Arch. Civ. Mech. Eng. 2019, 19, 898-941. [CrossRef]

3. Han, S.S. The influence of tool geometry on friction behavior in sheet metal forming. J. Mater. Process. Technol. 1997, 63, 129-133. [CrossRef]

4. Wang, P.Y.; Wang, Z.J.; Xiang, N.; Li, Z.X. Investigation on changing loading path in sheet metal forming by applying a property-adjustable flexible-die. J. Manuf. Process. 2020, 53, 364-375. [CrossRef]

5. Shisode, M.P.; Hazrati, J.; Mishra, T.; de Rooij, M.; van den Boogaard, T. Modeling mixed lubrication friction for sheet metal forming applications. Procedia Manuf. 2020, 47, 586-590. [CrossRef]

6. Evin, E.; Tomáš, M. Verification of models implemented in the simulation software. Mater. Sci. Forum 2020, 994, 223-231. [CrossRef]

7. Löfgren, H.B. A first order friction model for lubricated sheet metal forming. Theor. Appl. Mech. Lett. 2018, 8, 57-61. [CrossRef]

8. Figueiredo, L.; Ramalho, A.; Oliveira, M.C.; Menezes, L.F. Experimental study of friction in sheet metal forming. Wear 2011, 271, 1651-1657. [CrossRef]

9. Wang, W.; Zhao, Y.; Wang, Z.; Hua, M.; Wei, X. A study on variable friction model in sheet metal forming with advanced high strength steels. Tribol. Int. 2016, 93, 17-28. [CrossRef]

10. Wang, Z.; Gu, R.; Chen, S.; Wang, W.; Wei, X. Effect of upper-die temperature on the formability of AZ31B magnesium alloy sheet in stamping. J. Mater. Process. Technol. 2018, 257, 180-190. [CrossRef]

11. Kowalik, M.; Trzepiecinski, T. Examination of the influence of pressing parameters on strength and geometry of joint between aluminum plate and sheet metal. Arch. Civ. Mech. Eng. 2012, 12, 292-298. [CrossRef]

12. Seshacharyulu, K.; Bandhavi, C.; Naik, B.B.; Rao, S.S.; Singh, S.K. Understanding friction in sheet metal forming-A review. Mater. Today Proc. 2018, 5, 18238-18244. [CrossRef]

13. Jaworski, J.; Trzepieciński, T. Research on durability of turning tools made of low-alloy high-speed steels. Kov. Mater.-Met. Mater. 2016, 54, 17-25. [CrossRef]

14. Kirkhorn, L.; Bushlya, V.; Andersson, M.; Ståhl, J.E. The influence of tool steel microstructure on friction in sheet metal forming. Wear 2013, 302, 1268-1278. [CrossRef] 
15. Sulaiman, M.H.; Farahana, R.N.; Bienk, K.; Nielsen, C.V.; Bay, N. Effects of DLC/TiAlN-coated die on friction and wear in sheet-metal forming under dry and oil-lubricated conditions: Experimental and numerical studies. Wear, 2019; 438-439, 203040.

16. Wang, C.; Ma, R.; Zhao, J.; Zhao, J. Calculation method and experimental study of coulomb friction coefficient in sheet metal forming. J. Manuf. Process. 2017, 27, 126-137. [CrossRef]

17. Flegler, F.; Neuhäuser, S.; Groche, P. Influence of sheet metal texture on the adhesive wear and friction behaviour of EN AW-5083 aluminum under dry and starved lubrication. Tribol. Int. 2020, 141, 105956. [CrossRef]

18. Makhkamov, A.; Wagre, D.; Baptista, A.M.; Santos, A.D.; Malheiro, L. Tribology testing to friction determination in sheet metal forming processes. Ciência Tecnol. dos Mater. 2017, 29, e249-e253. [CrossRef]

19. Sigvant, M.; Pilthammar, J.; Hol, J.; Wiebenga, J.H.; Chezan, T.; Cerleer, B.; van den Boogard, T. Friction in sheet metal forming: Influence of surface roughness and strain rate on sheet metal forming simulaion results. Procedia Manuf. 2019, 29, 512-519. [CrossRef]

20. Ma, N.; Sugitomo, N. Development and application of non-linear friction models for metal forming simulation. AIP Conf. Proc. 2011, 1383, 382-389.

21. Ma, N.; Sugimoto, N. Nonlinear friction model for servo press simulation. AIP Conf. Proc. 2013, 1567, 918.

22. Trzepiecinski, T.; Lemu, H.G. Recent developments and trends in the friction testing for conventional sheet metal forming and incremental sheet forming. Metals 2020, 10, 47. [CrossRef]

23. Yuan, B.; Wang, Z. A multi-deformable bodies solution method coupling finite element with meshless method in sheet metal flexible-die forming. Procedia Eng. 2017, 207, 1641-1646. [CrossRef]

24. Jamli, M.R.; Farid, N.M. The sustainability of neural network applications within finite element analysis in sheet metal forming: A review. Measurement 2019, 138, 446-460. [CrossRef]

25. Ma, N.; Zhu, T.; Ogawa, R.; Liu, Y.; Harada, Y. Development of 3D Thick Shell and its Application to Sheet Metal Forming Simulation. In Proceedings of the 10th International Conference and Workshop on Numerical Simulation of 3D Sheet Metal Forming Processes Numisheet, Bristol, UK, 4-9 September 2016; pp. 5-6.

26. Topčagić, Z.; Križaj, D.; Bulić, E. Application of a current sheet in BEM analysis for numerical calculation of torque in the magnetostatic field. IEEE Trans. Magn. 2020, 56, 1-9. [CrossRef]

27. Siddiqui, M.A.; Correia, J.P.M.; Ahzi, S.; Belouettar, S. A numerical model to simulate electromagnetic sheet metal forming process. Int. J. Mater. Form. 2008, 1, 1387-1390. [CrossRef]

28. Kumar, R.U. Role of CFD in sheet metal forming. Int. J. Tech. Innov. Mod. Eng. Sci. 2018, 4, 458-462.

29. Zakaria, A.; Ibrahim, M.S.N.; Dezfouli, M.M.S. CFD evaluation of hot stamping die cooling system. Int. J. Eng. Technol. 2018, 7, 68-71. [CrossRef]

30. Saad, M.; Akhtar, S.; Srivastava, M.; Chaurasia, J. Role of simulation in metal forming processes. Mater. Today Proc. 2018, 5, 19576-19585. [CrossRef]

31. Wu, Y.; Shen, Y.; Chen, K.; Yu, Y.; He, G.; Wu, P. Multi-scale crystal plasticity finite element method (CPFEM) simulations for shear band development in aluminum alloys. J. Alloy. Compd. 2017, 711, 495-505. [CrossRef]

32. Mellbin, Y.; Hallberg, H.; Ristinmaa, M. A combined plasticity and graph-based vertex model of dynamic recrystallization at large deformations. Model. Simul. Mater. Sci. Eng. 2015, 23, 045011. [CrossRef]

33. da Silva, G.S.; Kosteski, L.E.; Iturrioz, I. Analysis of the failure process by using the Lattice Discrete Element Method in the Abaqus environment. Theoret. Appl. Fract. Mech. 2020, 107, 102563. [CrossRef]

34. Tallinen, T.; Åström, J.A.; Timonen, J. Discrete element simulations of crumpling of thin sheets. Comput. Phys. Commun. 2009, 180, 512-516. [CrossRef]

35. Xue, F.; Li, F.; Li, J.; He, M.; Yuan, Z.; Wang, R. Numerical modeling crack propagation of sheet metal forming based on stress state parameters using XFEM method. Comput. Mater. Sci. 2013, 69, 311-326. [CrossRef]

36. Gasiorek, D.; Baranowski, P.; Malachowski, J.; Mazurkiewicz, L.; Wiercigroch, M. Modelling of guillotine cutting of multi-layered aluminum sheets. J. Manuf. Process. 2018, 34, 374-388. [CrossRef]

37. Crutzen, Y.; Boman, R.; Papeleux, L.; Ponthot, J.P. Lagrangian and arbitrary Lagrangian Eulerian simulations of complex roll-forming processes. Comptes Rendus Mécanique 2016, 344, 251-266. [CrossRef]

38. Łach, Ł.; Nowak, J.; Svyetlichnyy, D. The evolution of the microstructure in AISI 304L stainless steel during the flat rolling - modeling by frontal cellular automata and verification. J. Mater. Process. Technol. 2018, 255, 488-499. [CrossRef] 
39. Yang, H.; Wu, C.; Li, H.; Fan, X.G. Review on cellular automata simulations of microstructure evolution during metal forming process: Grain coarsening, recrystallization and phase transformation. Sci. China Technol. Sci. 2011, 54, 2107-2118. [CrossRef]

40. Kochmann, J.; Wulfinghoff, S.; Reese, S.; Mianroodi, J.R.; Svendsen, B. Two-scale FE-FFT- and phase-field-based computational modeling of bulk microstructural evolution and macroscopic material behavior. Comput. Methods Appl. Mech. Eng. 2016, 305, 89-110. [CrossRef]

41. Hongyu, W.; Fei, T.; Zhen, W.; Pengchao, Z.; Juncai, S.; Shijun, J. Simulation research about rubber pad forming of corner channel with convex or concave mould. J. Manuf. Process. 2019, 40, 94-104. [CrossRef]

42. Li, T.; Garg, R.; Galvin, J.; Pannala, S. Open-source MFIX-DEM software for gas-solids flows: Part II-Validation studies. Powder Technol. 2012, 220, 138-150. [CrossRef]

43. Neuwirth, J.; Antonyuk, S.; Heinrich, S.; Jacob, M. CFD-DEM study and direct measurement of the granular flow in a rotor granulator. Chem. Eng. Sci. 2013, 86, 151-163. [CrossRef]

44. Martínez-Valle, Á.; Martínez-Jiménez, J.M.; Goes, P.; Faes, K.; De Waele, W. Multiphysics fully-coupled modelling of the electromagnetic compression of steel tubes. Adv. Mater. Res. 2011, 214, 31-39. [CrossRef]

45. Liu, X.; Sun, W.K.; Liew, K.M. Multiscale modeling of crystal plastic deformation of polycrystalline titanium at high temperatures. Comput. Methods Appl. Mech. Eng. 2018, 340, 932-955. [CrossRef]

46. Tolipov, A.A.; Elghawail, A.; Shushing, S.; Pham, D.; Essa, K. Experimental research and numerical optimisation of multi-point sheet metal forming implementation using a solid elastic cushion system. IOP Conf. Ser. J. Phys. 2017, 896, 012120. [CrossRef]

47. Ablat, M.A.; Quattawi, A. Numerical simulation of sheet metal forming: A review. Int. J. Adv. Manuf. Technol. 2017, 89, 1235-1250. [CrossRef]

48. Makinouchi, A.; Teodosiu, C.; Nakagawa, T. Advance in FEM simulation and its related technologies in sheet metal forming. CIRP Ann. -Manuf. Technol. 1998, 47, 641-649. [CrossRef]

49. Reis, F.J.P.; Pires, F.M.A. An adaptive sub-incremental strategy for the solution of homogenization-based multi-scale problems. Comput. Methods Appl. Mech. Eng. 2013, 257, 164-182. [CrossRef]

50. Coenen, E.W.C.; Kouznetsova, V.G.; Bosco, E.; Geers, M.G.D. A multi-scale approach to bridge microscale damage and macroscale failure: A nested computational homogenization-localization Framework. Int. J. Fract. 2012, 178, 157-178. [CrossRef]

51. Dong, G.J.; Bi, J.; Du, B.; Zhao, C.C. Research on AA6061 tubular components prepared by combined technology of heat treatment and internal high pressure forming. J. Mater. Process. Technol. 2017, 242, 126-138. [CrossRef]

52. Trzepieciński, T.; Lemu, H.G. Effect of computational parameters on springback prediction by numerical simulation. Metals 2017, 7, 380. [CrossRef]

53. Madej, L. Digital/virtual microstructures in application to metals engineering-A review. Arch. Civ. Mech. Eng. 2017, 17, 839-854. [CrossRef]

54. Perzyński, K.; Wrożyna, A.; Kuziak, R.; Legwand, A.; Madej, L. Development and validation of multi scale failure model for dual phase steel. Finite Elem. Anal. Des. 2017, 124, 7-21. [CrossRef]

55. Han, F.; Roters, F.; Raabe, D. Microstructure-based multiscale modeling of large strain plastic deformation by coupling a full-field crystal plasticity-spectral solver with an implicit finite element solver. Int. J. Plast. 2020, 125, 97-117. [CrossRef]

56. Gerasimov, D.; Gartvig, A. Parallel computing of metal forming simulation in QForm software. Comput. Methods Mater. Sci. 2016, 16, 139-142.

57. Alfaro, I.; Yvonnet, J.; Cueto, E.; Chinesta, F.; Doblare, M. Meshless methods with application to metal forming. Comput. Methods Appl. Mech. Eng. 2006, 195, 6661-6675. [CrossRef]

58. Liewald, M.; Riedmüller, K.R. A new one-phase material model for the numerical prediction of critical material flow conditions in thixoforging processes. CIRP Ann. 2019, 68, 293-296. [CrossRef]

59. Van Houtte, P.; Gawad, J.; Eyckens, P.; Van Bael, B.; Samaey, G.; Roose, D. Multi-scale modelling of the development of heterogeneous distributions of stress, strain, deformation texture and anisotropy in sheet metal forming. Procedia IUTAM 2012, 3, 67-75. [CrossRef]

60. Barik, S.K.; Narayanan, R.G.; Sahoo, N. Forming response of AA5052-H32 sheet deformed using a shock tube. Trans. Nonferrous Met. Soc. China 2020, 30, 603-618. [CrossRef]

61. Raju, C.; Haloi, N.; Narayanan, C.S. Strain distribution and failure mode in single point incremental forming (SPIF) of multiple commercially pure aluminum sheets. J. Manuf. Process. 2017, 30, 328-335. [CrossRef] 
62. Nakata, T.; Xu, C.; Ohashi, H.; Yoshida, Y.; Yoshida, K.; Kamado, S. New Mg-Al based alloy sheet with good room-temperature stretch formability and tensile properties. Scr. Mater. 2020, 180, 16-22. [CrossRef]

63. Badrish, A.; Morchhale, A.; Kotkunde, N.; Singh, S.K. Influence of material modeling on warm forming behavior of nickel based super alloy. Int. J. Mater. Form. 2020. [CrossRef]

64. Liu, X.; Li, H.; Zhan, M. A review on the modeling and simulations of solid-state diffusional phase transformations in metals and alloys. Manuf. Rev. 2018, 5, 10. [CrossRef]

65. Rodríguez-Martínez, J.A.; Rusinek, A.; Pesci, R.; Zaera, R. Experimental and numerical analysis of the martensitic transformation in AISI 304 steel sheets subjected to perforation by conical and hemispherical projectiles. Int. J. Solids Struct. 2013, 50, 339-351. [CrossRef]

66. Neto, D.M.; Oliveira, M.C.; Santos, A.D.; Alves, J.L.; Menezes, L.F. Influence of boundary conditions on the prediction of springback and wrinkling in sheet metal forming. Int. J. Mech. Sci. 2017, 122, $244-254$. [CrossRef]

67. Han, F.; Mo, J.H.; Qi, H.W.; Long, R.F.; Cui, X.H.; Li, Z.W. Springback prediction for incremental sheet forming based on FEM-PSONN technology. Trans. Nonferrous Met. Soc. China 2013, 23, 1061-1071. [CrossRef]

68. Basak, S.; Panda, S.K.; Lee, M.G. Formability and fracture in deep drawing sheet metals: Extended studies for pre-strained anisotropic thin sheets. Int. J. Mech. Sci. 2020, 170, 105346. [CrossRef]

69. Bansal, A.; Lingam, R.; Yadav, S.K.; Reddy, N.V. Prediction of forming forces in single point incremental forming. J. Manuf. Process. 2017, 28, 486-493. [CrossRef]

70. Abdelkader, W.B.; Bahloul, R.; Arfa, H. Numerical investigation of the influence of some parameters in SPIF process on the forming forces and thickness distributions of a bimetallic sheet CP-titanium/low-carbon steel compared to an individual layer. Procedia Manuf. 2020, 47, 1319-1327. [CrossRef]

71. Hu, Q.; Zhang, F.; Li, X.; Chen, J. Overview on the prediction models for sheet metal forming failure: Necking and ductile fracture. Acta Mech. Solida Sin. 2018, 31, 259-289. [CrossRef]

72. Amaral, R.; Santos, A.D.; de Sá José, C.; Miranda, S. Formability prediction for AHSS materials using damage models. J. Phys. Conf. Ser. 2017, 843, 012018. [CrossRef]

73. Oliveira, M.C.; Fernandes, J.V. Modelling and simulation of sheet metal forming processes. Metals 2019, 9, 1356. [CrossRef]

74. Madej, L.; Ambrozinski, M.; Kwiecien, M.; Gronostajski, Z.; Pietrzyk, M. Digital material representation concept applied to investigation of local inhomogeneities during manufacturing of magnesium components for automotive applications. Int. J. Mater. Res. 2017, 108, 3-11. [CrossRef]

75. Ma, N.; Takada, K.; Sato, K. Measurement of local strain path and identification of ductile damage limit based on simple tensile test. Procedia Eng. 2014, 81, 1402-1407. [CrossRef]

76. Takuda, H.; Hama, T.; Nishida, K.; Yoshida, T.; Nitta, J. Prediction of forming limit in stretch flanging by finite element simulation combined with ductile fracture criterion. Comp. Meth. Mater. Sci. 2009, 9, 137-142.

77. Ma, N.; Sato, K.; Takada, K. Analysis of local fracture strain and damage limit of advanced high strength steels using measured displacement fields and FEM. Comput. Mater. Contin. 2015, 46, 195-219.

78. Siswanto, W.A.; Anggono, A.D.; Omar, B.; Jusoff, K. An alternate method to springback compensation for sheet metal forming. Sci. World. J. 2014, 2014, 301271. [CrossRef] [PubMed]

79. Fekete, J.R.; Hall, J.N.; Meuleman, D.J.; Rupp, M. Progress in implementation of advanced high-strength steels into vehicle structures. Iron Steel Technol. 2008, 5, 55-64.

80. Lingbeek, R.A.; Huetink, H.; Ohnimus, S.; Weiher, J. Iterative Springback Compensation of NUMISHEET Benchmark \#1. In Proceedings of the 6th International Conference and Workshop on Numerical Simulation of 3D Sheet Metal Forming Processes, NUMISHEET 2005, Detroit, MI, USA, 15-19 August 2005; pp. 1-6.

81. Ren, H.; Xie, J.; Liao, S.; Leem, D.; Cao, J. In-situ springback compensation in incremental sheet forming. CIRP Ann. 2019, 68, 317-320. [CrossRef]

82. Li, Y.; Liang, Z.; Zhang, Z.; Zou, T.; Shi, L. An analytical model for rapid prediction and compensation of springback for chain-die forming of an AHSS U-channel. Int. J. Mech. Sci. 2019, 159, 195-212. [CrossRef]

83. Zheng, K.; Politis, D.J.; Wang, L.; Lin, J. A review on forming techniques for manufacturing lightweight complex-Shaped aluminium panel components. Int. J. Light. Mater. Manuf. 2018, 1, 55-80. [CrossRef]

84. Alghtani, A.; Brooks, P.C.; Barton, D.C.; Toropov, V.V. Springback Analysis and Optimization in Sheet Metal Forming. In Proceedings of the 9th European LS-DYNA Conference, Menchester, UK, 3-4 June 2013; pp. 1-11.

85. Ma, N.; Sugitomo, N. Dynamic explicit FEM and simulation on sheet metal forming. J. Jpn. Soc. Technol. Plast. 2006, 47, 29-34. [CrossRef] 
86. Kato, Y.; Umezu, Y.; Watanabe, Y. Recent Developments in JSTAMP/NV for the Best Stamping Simulation Environment. In Proceedings of the 11th International LS-DYNA Users Conference, Dearborn, MI, USA, 6-8 June 2010.

87. Shindo, T.; Sugimoto, N.; Ma, N. Springback simulation and compensation for high strength parts using JSTAMP. AIP Conf. Proc. 2011, 1383, 1086-1091.

88. Ma, N.; Zhu, X. Computational stoning method for surface defect detection. AIP Conf. Proc. 2013, 1567, 728-731.

89. Transparent Reporting of Systematic Reviews and Meta-Analyses. Available online: http://prisma-statement. org/ (accessed on 7 April 2020).

90. Engel, U.; Eckstein, R. Microforming - from basic research to its realization. J. Mater. Process. Technol. 2002, 125, 35-44. [CrossRef]

91. Fu, M.W.; Chan, W.L. A review on the state-of-the-art microforming technologies. Int. J. Adv. Manuf. Technol. 2013, 67, 2411-2437. [CrossRef]

92. Zheng, J.Y.; Yang, H.P.; Fu, M.W.; Ng, C. Study on size effect affected progressive microforming of conical flanged parts directly using sheet metals. J. Mater. Process. Technol. 2019, 272, 72-86. [CrossRef]

93. Furushima, T.; Tsunezaki, H.; Manabe, K.I.; Alexsandrov, S. Ductile fracture and free surface roughening behaviors of pure copper foils for micro/meso-scale forming. Int. J. Mach. Tools Manuf. 2014, 76, 34-48. [CrossRef]

94. Mao, M.Y.; Peng, L.F.; Fu, M.W.; Lai, X.M. Co-effect of microstructure and surface constraints on plastic deformation in micro- and mesoscaled forming process. Int. J. Adv. Manuf. Technol. 2018, 98, 1861-1886. [CrossRef]

95. Cheng, C.; Wan, M.; Meng, B.; Zhao, Z.; Han, W.P. Size effect on the yield behavior of metal foil under multiaxial stress states: Experimental investigation and modelling. Int. J. Mech. Sci. 2019, 151, 760-771. [CrossRef]

96. Wang, Z.; Li, S.; Wang, X.; Cui, R.; Zhang, W. Modeling of surface layer and strain gradient hardening effects on micro-bending of non-oriented silicon steel sheet. Mater. Sci. Eng. A 2018, 711, 498-507. [CrossRef]

97. Cheng, T.C.; Lee, R.S. The influence of grain size and strain rate effects on formability of aluminium alloy sheet at high-speed forming. J. Mater. Process. Technol. 2018, 253, 134-159. [CrossRef]

98. Lin, B.T.; Huang, K.M.; Kuo, C.C.; Wang, W.T. Improvement of deep drawability by using punch surfaces with microridges. J. Mater. Process. Technol. 2015, 225, 275-285. [CrossRef]

99. Wang, X.; Xu, J.; Jiang, Z.; Zhu, W.L.; Shan, D.; Guo, B.; Cao, J. Size effects on flow stress behavior during electrically-assisted micro-tension in a magnesium alloy AZ31. Mater. Sci. Eng. A 2016, 659, $215-224$. [CrossRef]

100. Xu, Z.; Peng, L.; Bao, E. Size effect affected springback in micro/meso scale bending process: Experiments and numerical modeling. J. Mater. Process. Technol. 2018, 252, 407-420. [CrossRef]

101. Wang, J.L.; Fu, M.W.; Ran, J.Q. Analysis of the size effect on springback behavior in micro-scaled U-bending process of sheet metals. Adv. Eng. Mater. 2014, 16, 421-432. [CrossRef]

102. Fu, M.W.; Chan, W.L. Geometry and grain size effects on the fracture behavior of sheet metal in micro-scale plastic deformation. Mater. Des. 2011, 32, 4738-4746. [CrossRef]

103. Ran, J.Q.; Fu, M.W.; Chan, W.L. The influence of size effect on the ductile fracture in micro-scaled plastic deformation. Int. J. Plast. 2013, 41, 65-81. [CrossRef]

104. Chan, W.L.; Fu, M.W. Experimental and simulation based study on micro-scaled sheet metal deformation behavior in microembossing process. Mater. Sci. Eng. A 2012, 556, 60-67. [CrossRef]

105. Chan, W.L.; Fu, M.W. Experimental studies of plastic deformation behaviors in microheading process. J. Mater. Process. Technol. 2012, 212, 1501-1512. [CrossRef]

106. Rosochowski, A.; Presz, W.; Olejnik, L.; Richert, M. Micro-extrusion of ultra-fine grained aluminium. Int. J. Adv. Manuf. Technol. 2007, 33, 137-146. [CrossRef]

107. Meng, B.; Fu, M.W.; Shi, S.Q. Deformation characteristic and geometrical size effect in continuous manufacturing of cylindrical and variable-thickness flanged microparts. J. Mater. Process. Technol. 2018, 252, 546-558. [CrossRef]

108. Sato, H.; Manabe, K.I.; Wei, D.; Jiang, Z.; Alexandrov, S. Tribological behavior in micro-sheet hydroforming. Tribol. Int. 2016, 97, 302-312. [CrossRef] 
109. Mahabunphachai, S.; Cora, O.N.; Koç, M. Effect of manufacturing processes on formability and surface topography of protonexchange membrane fuel cell metallic bipolar plates. J. Power. Sources 2010, 195, 5269-5277. [CrossRef]

110. Liu, Y.; Hua, L. Fabrication of metallic bipolar plate for protonexchange membrane fuel cells by rubber pad forming. J. Power Sources 2010, 195, 3529-3535. [CrossRef]

111. Peng, L.; Hu, X.; Mei, D.; Ni, J. Investigation of micro/meso sheet soft punch stamping process - simulation and experiments. Mater. Des. 2009, 30, 783-790. [CrossRef]

112. Lim, S.S.; Kim, Y.T.; Kang, C.G. Fabrication of aluminum 1050 micro-channel proton exchange membrane fuel cell bipolar plate using rubber-pad-forming process. Int. J. Adv. Manuf. Technol. 2013, 65, 231-238. [CrossRef]

113. Elyasi, M.; Khatir, F.A.; Hosseinzadeh, M. Manufacturing metallic bipolar plate fuel cells through rubber pad forming process. Int. J. Adv. Manuf. Technol. 2017, 89, 3257-3269. [CrossRef]

114. Morales, M.; Porro, J.A.; García-Ballesteros, J.J.; Molpeceres, C.; Ocaña, J.L. Effect of plasma confinement on laser shock microforming of thin metal sheets. Appl. Surf. Sci. 2011, 257, 5408-5412. [CrossRef]

115. Ocaña, J.L.; Morales, M.; García-Ballesteros, J.J.; Porro, J.A.; García, O.; Molpeceres, C. Laser shock microforming of thin metal sheets. Appl. Surf. Sci. 2009, 255, 5633-5636. [CrossRef]

116. Shen, Z.; Gu, C.; Liu, H.; Wang, X. An experimental study of overlapping laser shock micro-adjustment using a pulsed Nd:YAG laser. Opt. Laser Technol. 2013, 54, 110-119. [CrossRef]

117. Risch, D.; Beerwald, C.; Brosius, A.; Kleiner, M. On the significance of the die design for electromagnetic sheet metal forming. In Proceedings of the 1st International Conference on High Speed Forming, Dortmund, Germany, 31 March-1 April 2004; pp. 191-200.

118. Shen, Z.; Wang, X.; Liu, H.; Wang, Y.; Wang, C. Rubber-induced uniform laser shock wave pressure for thin metal sheets microforming. Appl. Surf. Sci. 2015, 327, 307-312. [CrossRef]

119. Kuhfuss, B.; Schattmann, C.; Jahn, M.; Schmidt, A.; Vollertsen, F.; Moumi, E.; Schenck, C.; Herrmann, M.; Ishkina, S.; Rathmann, L.; et al. Micro forming processes. In Cold Micro Metal Forming, 1st ed.; Vollertsen, F., Friedrich, S., Kuhfuß, B., Maaß, P., Thomy, C., Zoch, H.W., Eds.; Springer: Cham, Switzerland, 2020; pp. $27-94$.

120. Thomy, C.; Wilhelmi, P.; Onken, A.K.; Schenck, C.; Kuhfuss, B.; Tracht, K.; Rippel, D.; Lütjen, M.; Freitag, M. Process design. In Cold Micro Metal Forming, 1st ed.; Vollertsen, F., Friedrich, S., Kuhfuß, B., Maaß, P., Thomy, C., Zoch, H.W., Eds.; Springer: Cham, Switzerland, 2020; pp. 95-132.

121. Vollertsen, F.; Seven, J.; Messaoudi, H.; Mikulewitsch, M.; Fischer, A.; Goch, G.; Mehrafsun, S.; Riemer, O.; Maaß, P.; Böhmermann, F.; et al. Tooling. In Cold Micro Metal Forming, 1st ed.; Vollertsen, F., Friedrich, S., Kuhfuß, B., Maaß, P., Thomy, C., Zoch, H.W., Eds.; Springer: Cham, Switzerland, 2020; pp. 133-251.

122. Maaß, P.; Piotrowska-Kurczewski, I.; Agour, M.; von Freyberg, A.; Staar, B.; Falldorf, C.; Fischer, A.; Lütjen, M.; Freitag, M.; Goch, G.; et al. Quality control and characterization. In Cold Micro Metal Forming, 1st ed.; Vollertsen, F., Friedrich, S., Kuhfuß, B., Maaß, P., Thomy, C., Zoch, H.W., Eds.; Springer: Cham, Switzerland, 2020; pp. 253-310.

123. Trzepieciński, T.; Pieja, T.; Malinowski, T.; Smusz, R.; Motyka, M. Investigation of 17-4PH steel microstructure and conditions of elevated temperature forming of turbine engine strut. J. Mater. Process. Technol. 2018, 252, 191-200. [CrossRef]

124. Takuhiro, S.; Suzuki, N.; Takeuchi, O. Culinder forming by die-less shear spinning with sheet thickness controlling of its wall. Procedia Manuf. 2018, 15, 1232-1238. [CrossRef]

125. Lade, J.; Banoth, B.N.; Gupta, A.K.; Singh, S.K. Metallurgical studies of austenitic stainless steel 304 under warm deep drawing. J. Iron Steel Res. Int. 2014, 21, 1147-1151. [CrossRef]

126. Afshin, E.; Kadkhodayan, M. An experimental investigation into the warm deep-drawing process on laminated sheets under various grain sizes. Mater. Des. 2015, 87, 25-35. [CrossRef]

127. Panicker, S.S.; Panda, S.K. Investigations into improvement in formability of AA5754 and AA6082 sheets at elevated temperatures. J. Mater. Eng. Perform. 2019, 28, 2967-2982. [CrossRef]

128. Zhang, Z.; Xu, Y.; Yuan, S. Analysis of thickness variation of reverse deep drawing of preformed 5A06 aluminum alloy cup under different temperatures. Int. J. Adv. Manuf. Technol. 2016, 86, 521-529. [CrossRef]

129. Liu, S.; Long, M.; Ai, S.; Zhao, Y.; Chen, D.; Feng, Y.; Duan, H.; Ma, M. Evolution of phase transition and mechanical properties of ultra-high strength hot-stamped steel during quenching process. Metals 2020, 10, 138. [CrossRef] 
130. Kayhan, E.; Kaftanoglu, B. Experimental investigation of non-isothermal deep drawing of DP600 steel. Int. J. Adv. Manuf. Technol. 2018, 99, 695-706. [CrossRef]

131. Singh, K.; Mahesh, K.; Gupta, A.K. Prediction of mechanical properties of extra deep drawn steel in blue brittle region using artificial neural Network. Mater. Des. 2010, 31, 2288-2295. [CrossRef]

132. Krishna, P.G.; Venugopal, L.; Prabhu, T.R. Experimental investigation of failures in redrawing of Ti-6Al-4V alloy at warm conditions. Mater. Today Proc. 2017, 4, 8478-8485. [CrossRef]

133. Panicker, S.S.; Prasad, K.S.; Sawale, G.; Hazra, S.; Shollock, B.; Panda, S.K. Warm redrawing of AA6082 sheets and investigations into the effect of aging heat treatment on cup wall strength. Mater. Sci. Eng. A 2019, 768, 138445. [CrossRef]

134. Hussaini, S.M.; Krishna, G.; Gupta, A.K.; Singh, S.K. Development of experimental and theoretical forming limit diagrams for warm forming of austenitic stainless steel 316. J. Manuf. Process. 2015, 18, 151-158. [CrossRef]

135. Keum, Y.T.; Han, B.Y. Springback of FCC sheet in warm forming. J. Ceram. Process. Res. 2002, 3, $159-165$.

136. Chen, F.K.; Huang, T.B. Formability of stamping magnesium-alloy AZ31 sheets. J. Mater. Process. Technol. 2003, 142, 643-647. [CrossRef]

137. Oliveira, M.C.; Alves, J.L.; Chaparro, B.M.; Menezes, L.F. Study on the influence of work-hardening modeling in springback prediction. Int. J. Plast. 2007, 23, 516-543. [CrossRef]

138. Billur, E. Warm Hydroforming Characteristics of Stainless Steel Sheet Metals. Master's Thesis, Virginia University, Richmond, VA, USA, 2018.

139. Laurent, H.; Coër, J.; Manach, P.Y.; Oliveira, M.C.; Menezes, L.F. Experimental and numerical studies on the warm deep drawing of an Al-Mg Allom. Int. J. Mech. Sci. 2015, 93, 59-72. [CrossRef]

140. Harrison, N.R.; Friedman, P.A. Warm forming die design, Part II: Parting surface temperature response characterization of a novel thermal finite element modeling code. J. Manuf. Process. 2014, 16, 312-319. [CrossRef]

141. Harrison, N.R.; Friedman, P.A.; Pan, J. Warm forming die design, Part III: Design and validation of a warm forming die. J. Manuf. Process. 2015, 20, 356-366. [CrossRef]

142. Davis, J.R. ASM Specialty Handbook: Heat-Resistant Materials; ASM International: Materials Park, OH, USA, 1997; pp. 3-66.

143. Martins, J.M.P.; Alves, J.L.; Neto, D.M.; Oliveira, M.C.; Menezes, L.F. Numerical analysis of different heating systems for warm sheet metal forming. Int. J. Adv. Manuf. Technol. 2016, 83, 897-909. [CrossRef]

144. Hasanuzzaman, M.; Rahim, N.A.; Hosenuzzaman, M.; Saidur, R.; Mahbubul, I.M.; Rashid, M.M. Energy savings in the combustion based process heating in industrial sector. Renew. Sustain. Energy Rev. 2012, 16, 4527-4536. [CrossRef]

145. Harrison, N.R.; Ilinich, A.; Friedman, P.; Singh, J.; Verma, R. Optimization of high-volume warm forming for lightweight sheet. SAE Tech. Pap. 2013, 2013-01-1170. [CrossRef]

146. Bong, H.J.; Barlat, F.; Ahn, D.C.; Kim, H.Y.; Lee, M.G. Formability of austenitic and ferritic stainless steels at warm forming temperature. Int. J. Mech. Sci. 2013, 75, 94-109. [CrossRef]

147. Gronostajski, Z.; Niechajowicz, A.; Kuziak, R.; Krawczyk, J.; Polak, S. The effect of the strain rate on the stress-strain curve and microstructure of AHSS. J. Mater. Process. Technol. 2017, 242, 246-259. [CrossRef]

148. Wiewiórowska, S.; Muskalski, Z. The application of low and medium carbon steel with multiphase TRIP structure in drawing industry. Procedia Manuf. 2015, 2, 181-185. [CrossRef]

149. Cai, Z.; Wan, M.; Liu, Z.; Wu, X.; Ma, B.; Cheng, C. Thermal-mechanical behaviors of dual-phase steel sheet under warm-forming conditions. Int. J. Mech. Sci. 2017, 126, 79-94. [CrossRef]

150. Maeno, T.; Mori, K.; Nagai, T. Improvement in formability by control of temperature in hot stamping of ultra-high strength steel parts. CIRP Ann. 2014, 63, 301-304. [CrossRef]

151. Tokita, Y.; Nakagaito, T.; Tamai, Y.; Urabe, T. Stretch formability of high strength steel sheets in warm forming. J. Mater. Process. Technol. 2017, 246, 77-84. [CrossRef]

152. Saito, N.; Fukahori, M.; Hisano, D.; Hamasaki, H.; Yoshida, F. Effects of temperature, forming speed and stress relaxation on springback in warm forming of high strength steel sheet. Procedia Eng. 2017, 207, 2394-2398. [CrossRef]

153. Kumar, M.; Sotirov, N.; Chimani, C.M. Investigations on warm forming of AW-7020-T6 alloy sheet. J. Mater. Process. Technol. 2014, 214, 1769-1776. [CrossRef] 
154. Grimes, R.; Janik, V. Automotive applications for magnesium. In Encyclopedia of Automotive Engineering; Crolla, D., Foster, D.E., Kobayashi, T., Vaughan, N., Eds.; John Wiley \& Sons, Inc.: Hoboken, NJ, USA, 2014; pp. 3101-3123.

155. Zhang, R.; Shao, Z.; Lin, J. A review on modelling techniques for formability prediction of sheet metal forming. Int. J. Light. Mater. Manuf. 2018, 1, 115-125. [CrossRef]

156. Martins, J.M.P.; Neto, D.M.; Alves, J.L.; Oliveira, M.C.; Laurent, H.; Andrade-Campos, A.; Menezes, L.F. A new staggered algorithm for thermomechanical coupled problems. Int. J. Solids Struct. 2017, 122-123, 42-58. [CrossRef]

157. Harrison, N.R.; Rubek, V.; Friedman, P.A. Warm forming die design, part I: Experimental validation of a novel thermal finite element modeling code. J. Manuf. Process. 2013, 15, 263-272. [CrossRef]

158. Abovyan, T.; Kridli, G.T.; Friedman, P.A.; Ayoub, G. Formability prediction of aluminum sheet alloys under isothermal forming conditions. J. Manuf. Process. 2015, 20, 406-413. [CrossRef]

159. Neto, D.M.; Martins, J.M.P.; Cunha, P.M.; Alves, J.L.; Oliveira, M.C.; Laurent, H.; Menezes, L.F. Thermo-mechanical finite element analysis of the AA5086 alloy under warm forming conditions. Int. J. Solids Struct. 2017, 151, 99-117. [CrossRef]

160. Panicker, S.S.; Singh, H.G.; Panda, S.K.; Dashwood, R. Characterization of tensile properties, limiting strains, and deep drawing behavior of AA5754-H22 sheet at elevated temperature. J. Mater. Eng. Perform. 2015, 24, 4267-4282. [CrossRef]

161. Pourboghrat, F.; Venkatesan, S.; Carsley, J.E. LDR and hydroforming limit for deep drawing of AA5754 aluminum sheet. J. Manuf. Process. 2013, 15, 600-615. [CrossRef]

162. Wang, W.; Huang, L.; Tao, K.; Chen, S.; Wei, X. Formability and numerical simulation of AZ31B magnesium alloy sheet in warm stamping process. Mater. Des. 2015, 87, 835-844. [CrossRef]

163. Al-Samman, T.; Gottstein, G. Room temperature formability of a magnesium AZ31 alloy: Examining the role of texture on the deformation mechanisms. Mater. Sci. Eng. A 2008, 488, 406-414. [CrossRef]

164. Uemori, T.; Katahira, T.; Naka, T.; Tada, N.; Yoshida, F. Cyclic stress and strain responses of AZ31 magnesium alloy sheet metal at elevated temperatures. Procedia Manuf. 2018, 15, 1792-1799. [CrossRef]

165. Balasubramanian, S.; Anand, L. Plasticity of initially textured hexagonal polycrystals at high homologous temperatures: Application to titanium. Acta Mater. 2002, 50, 133-148. [CrossRef]

166. Maksoud, I.A.; Ahmed, H.; Rödel, J. Investigation of the effect of strain rate and temperature on the deformability and microstructure evolution of AZ31 magnesium alloy. Mater. Sci. Eng. A 2009, 504, 40-48. [CrossRef]

167. Liang, S.J.; Liu, Z.Y.; Wang, E.D. Simulation of extrusion process of AZ31 magnesium alloy. Mater. Sci. Eng. A 2009, 499, 221-224. [CrossRef]

168. Ramezani, M.; Neitzert, T.; Pasang, T.; Sellès, M.A. Characterization of friction behaviour of AZ80 and ZE10 magnesium alloys under lubricated contact condition by strip draw and bend test. Int. J. Mach. Tools Manuf. 2014, 85, 70-78. [CrossRef]

169. Abu-Farha, F.; Verma, R.; Hector, L.G. High temperature composite forming limit diagrams of four magnesium AZ31B sheets obtained by pneumatic stretching. J. Mater. Process. Technol. 2014, 212, 1414-1429. [CrossRef]

170. Atrian, A.; Fereshteh-Saniee, F. Deep drawing process of steel/brass laminated sheets. Compos. Part. B 2013, 47, 75-81. [CrossRef]

171. Rajabi, A.; Kadkhodayan, M.; Manoochehri, M.; Farjadfar, R. Deep-drawing of thermoplastic metal-composite structures: Experimental investigations, statistical analyses and finite element modeling. J. Mater. Process. Technol. 2015, 215, 159-170. [CrossRef]

172. Gali, O.A.; Riahi, A.R.; Alpas, A.T. The tribological behaviour of AA5083 alloy plastically deformed at warm forming temperatures. Wear 2016, 302, 1257-1267. [CrossRef]

173. Jaworski, J.; Kluz, R.; Trzepieciński, T. Operational tests of wear dynamics of drills made of low-alloy high-speed hs2-5-1 steel. Eksploat. i Niezawodn.-Maint. Reliab. 2016, 18, 271-277. [CrossRef]

174. Pelcastre, L. Hot Forming Tribology: Galling of Tools and Associated Problems. Licentiate Thesis, Luleå University of Technology, Lulea, Sweden, 2011.

175. Kondratiuk, J.; Kuhn, P. Tribological investigations on friction and wear behaviour of coatings for hot sheet metal forming. Wear 2011, 270, 839-849. [CrossRef]

176. Wu, C.; Qu, P.; Zhang, L.; Li, S.; Jiang, Z. A Numerical and experimental study on the interface friction of ball-on-disc test under high temperature. Wear 2017, 376-377, 433-442. [CrossRef] 
177. Venema, J.; Matthews, D.T.A.; Hazrati, J.; Wörmann, J.; van den Boogaard, A.H. Friction and wear mechanisms during hot stamping of AlSi coated press hardening steel. Wear 2017, 380-381, 137-145. [CrossRef]

178. Uda, K.; Azushima, A.; Yanagida, A. Development of new lubricants for hot stamping of Al-coated 22MnB5 steel. J. Mater. Process. Technol. 2016, 228, 112-116. [CrossRef]

179. Bay, N.; Azushima, A.; Groche, P.; Ishibashi, I.; Merklein, M.; Morishita, M.; Nakamura, T.; Schmid, S.; Yoshida, M. Environmentally benign tribo-systems for metal forming. CIRP Ann. 2010, 59, 760-780. [CrossRef]

180. Dohda, K.; Boher, C.; Reza-Aria, F.; Mahayotsanun, N. Tribology in metal forming at elevated temperatures. Friction 2015, 3, 1-27. [CrossRef]

181. Leszak, E. Apparatus and Process for Incremental Dieless Forming. U.S. Patent 3342051A1, 19 September 1967.

182. Pathak, J. A brief review on incremental sheet metal forming. Int. J. Latest Eng. Manag. Res. 2017, 2, 35-43.

183. Xu, D.K.; Lu, B.; Cao, T.T.; Zhang, H.; Chen, J.; Hong, H.; Cao, J. Enhancement of process capabilities in electrically-assisted double sided incremental forming. Mater. Des. 2016, 92, 268-280. [CrossRef]

184. Vahdati, M.; Mahdavinejad, R.; Amini, S. Investigation of the ultrasonic vibration effect in incremental sheet metal forming process. Proc. Inst. Mech. Eng. Part B J. Eng. Manuf. 2017, 231, 971-998. [CrossRef]

185. Amini, S.; Gollo, A.H.; Paktinat, H. An investigation of conventional and ultrasonic-assisted incremental forming of annealed AA1050 sheet. Int. J. Adv. Manuf. Technol. 2017, 90, 1569-1578. [CrossRef]

186. Al-Obaidai, A.; Kunke, A.; Kräusel, V. Hot single-point incremental forming of glass-fiber-reinforced polymer(PA6GF47) supported by hot air. J. Manuf. Process. 2019, 43, 17-25. [CrossRef]

187. Ai, S.; Long, H. A review on material fracture mechanism in incremental sheet forming. Int. J. Adv. Manuf. Technol. 2019, 104, 33-61. [CrossRef]

188. Xiao, X.; Kim, C.; Lv, X.; Hwang, T.S.; Kim, Y.S. Formability and forming force in incremental sheet forming of AA7075-T6 at different temperatures. J. Mech. Sci. Technol. 2019, 33, 3795-3802. [CrossRef]

189. Kumar, A.; Gulati, V.; Kumar, P.; Singh, H. Forming force in incremental sheet forming: A comparative analysis of the state of the art. J. Braz. Soc. Mech. Sci. Eng. 2019, 41, 251. [CrossRef]

190. Fan, G.; Gao, L.; Hussain, G.; Wu, Z. Electric hot incremental forming: A novel technique. Int. J. Mach. Tool. Manuf. 2008, 48, 1688-1692. [CrossRef]

191. Kurra, S.; Rahman, N.; Regalla, S.; Gupta, A. Modeling and optimization of surface roughness in single point incremental forming process. J. Mater. Res. Technol. 2015, 4, 304-313. [CrossRef]

192. Rauch, M.; Hascoet, J.; Hamann, J.; Plenel, Y. Tool path programming optimization for incremental sheet forming applications. Comput. Aided Des. 2009, 41, 877-885. [CrossRef]

193. Oleksik, V. Influence of Geometrical Parameters, Wall Angle and Part Shape on Thickness Reduction of Single Point Incremental Forming. Procedia Eng. 2014, 81, 2280-2285. [CrossRef]

194. Al-Ghamdi, K.A.; Hussain, G. On the Free-Surface Roughness in Incremental Forming of a Sheet Metal: A Study from the Perspective of ISF Strain, Surface Morphology, Post-Forming Properties, and Process Conditions. Metals 2019, 9, 553. [CrossRef]

195. Slota, J.; Krasowski, B.; Kubit, A.; Trzepiecinski, T.; Bochnowski, W.; Dudek, K.; Neslušan, M. Residual stresses and surface roughness analysis of truncated cones of steel sheet made by single point incremental forming. Metals 2020, 10, 237. [CrossRef]

196. Jadhav, S. Basic Investigations of the Incremental Sheet Metal Forming Process on a CNC Milling Machine; Shaker Verlag GmbH: Aachen, Germany, 2004.

197. Hirt, G.; Ames, J.; Bambach, M. Basic investigation into the characteristics of dies and support tools used in CNC-incremental sheet forming. In Proceedings of the 25th IDDRG Conference, Porto, Portugal, 19-21 June 2006; pp. 341-348.

198. Martins, P.A.F.; Bay, N.; Skjoedt, M.; Silva, M.B. Theory of single point incremental forming. CIRP Ann. Manuf. Technol. 2008, 57, 247-252. [CrossRef]

199. Behera, A.K.; de Sousa, R.A.; Ingarao, G.; Oleksik, V. Single point incremental forming: An assessment of the progress and technology trends from 2005 to 2015. J. Manuf. Process. 2017, 27, 37-62. [CrossRef]

200. Durante, M.; Formisano, A.; Langella, A.; Minutolo, F. The influence of tool rotation on an incremental forming process. J. Mater. Process. Technol. 2009, 209, 4621-4626. [CrossRef]

201. Obikawa, T.; Satou, S.; Hakutani, T. Dieless incremental micro-forming of miniature shell objects of aluminium foils. Int. J. Mach. Tool. Manuf. 2009, 49, 906-915. [CrossRef] 
202. Duflou, J.R.; Callebaut, B.; Verbert, J.; De Baerdemaeker, D. Laser assisted incremental forming: Formability and accuracy improvement. CIRP Ann. 2007, 56, 273-276. [CrossRef]

203. Göttmann, A.; Diettrich, J.; Bergweiler, G.; Bambach, M.; Hirt, G.; Loosen, P.; Poprawe, R. Laser-assisted asymmetric incremental sheet forming of titanium sheet metal parts. Prod. Eng. 2011, 5, 263-271. [CrossRef]

204. Göttmann, A.; Bailly, D.; Bergweiler, G.; Bambach, M.; Stollenwerk, J.; Hirt, G.; Loosen, P. A novel approach for temperature control in ISF supported by laser and resistance heating. Int. J. Adv. Manuf. Technol. 2013, 67, 2195-2205. [CrossRef]

205. Mohammadi, A.; Vanhove, H.; Van Bael, A.; Duflou, J.R. Towards accuracy improvement in single point incremental forming of shallow parts formed under laser assisted conditions. Int. J. Mater. Form. 2016, 9 , 339-351. [CrossRef]

206. Mohammadi, A.; Qin, L.; Vanhove, H.; Seefeldt, M.; Van Bael, A.; Duflou, J.R. Single point incremental forming of an aged AL-Cu-Mg alloy: Influence of pre-heat treatment and warm forming. J. Mater. Eng. Perform. 2016, 25, 2478-2488. [CrossRef]

207. Kim, S.W.; Lee, Y.S.; Kang, S.H.; Lee, J.H. Incremental forming of Mg alloy sheet at elevated temperatures. J. Mech. Sci. Technol. 2007, 21, 1518-1522. [CrossRef]

208. Galdos, L.; Argandona, E.S.D.; Ulacia, I.; Arruebarrena, G. Warm incremental forming of magnesium alloys using hot fluid as heating media. Key Eng. Mater. 2012, 504-506, 815-820. [CrossRef]

209. Al-Obaidi, A.; Kräusel, V.; Landgrebe, D. Hot single-point incremental forming assisted by induction heating. Int. J. Adv. Manuf. Technol. 2015, 82, 1163-1171. [CrossRef]

210. Al-Obaidi, A.; Kräusel, V.; Landgrebe, D. Induction Heating Validation of Dieless Single-Point Incremental Forming of AHSS. J. Manuf. Mater. Process. 2017, 1, 5. [CrossRef]

211. Baharudin, B.; Azpen, Q.; Sulaima, S.; Mustapha, F. Experimental Investigation of Forming Forces in Frictional Stir Incremental Forming of Aluminum Alloy AA6061-T6. Metals 2017, 7, 484. [CrossRef]

212. Kim, S.W.; Lee, Y.S.; Kwon, Y.N.; Lee, J.H. A Study on Warm Incremental Forming of AZ31 Alloy Sheet. Trans. Mater. Process. 2008, 17, 373-379.

213. Ji, Y.H.; Park, J.J. Incremental forming of free surface with magnesium alloy AZ31 sheet at warm temperatures. Trans. Nonferrous Met. Soc. China 2008, 18, s165-s169. [CrossRef]

214. Ji, Y.H.; Park, J.J. Formability of magnesium AZ31 sheet in the incremental forming at warm temperature. J. Mater. Process. Technol. 2008, 201, 354-358. [CrossRef]

215. Xu, D.; Lu, B.; Cao, T.; Chen, J.; Long, H.; Cao, J. A comparative study on process potentials for frictional stirand electric hot-assisted incremental sheet forming. Procedia Eng. 2014, 81, 2324-2329. [CrossRef]

216. Ambrogio, G.; Gagliardi, F. Temperature variation during high speed incremental forming on different lightweight alloys. Int. J. Adv. Manuf. Technol. 2015, 76, 1819-1825. [CrossRef]

217. Ambrogio, G.; Gagliardi, F.; Chamanfar, A.; Misiolek, W.Z.; Filice, L. Induction heating and cryogenic cooling in single point incremental forming of Ti-6Al-4V: Process setup and evolution of microstructure and mechanical properties. Int. J. Adv. Manuf. Technol. 2017, 91, 803-812. [CrossRef]

218. Ambrogio, G.; Gagliardi, F.; Bruschi, S.; Filice, L. On the high-speed single point incremental forming of titanium alloys. CIRP Ann. 2013, 62, 243-246. [CrossRef]

219. Buffa, G.; Campanella, D.; Fratini, L. On the improvement of material formability in SPIF operation through tool stirring action. Int. J. Adv. Manuf. Technol. 2013, 66, 1343-1351. [CrossRef]

220. Davarpanah, M.A.; Mirkouei, A.; Yu, X.; Malhotra, R.; Pilla, S. Effects of incremental depth and tool rotation on failure modes and microstructural properties in single point incremental forming of polymers. J. Mater. Process. Technol. 2015, 222, 287-300. [CrossRef]

221. Wang, J.; Li, L.; Jiang, H. Effects of forming parameters on temperature in frictional stir incremental sheet forming. J. Mech. Sci. Technol. 2016, 30, 2163-2169. [CrossRef]

222. Liu, Z. Friction stir incremental forming of AA7075-O sheets: Investigation on process feasibility. Procedia Eng. 2017, 207, 783-788. [CrossRef]

223. Uheida, E.H.; Oosthuizen, G.A.; Dimitrov, D.M.; Bezuidenhout, M.B.; Hugo, P.A. Effects of the relative tool rotation direction on formability during the incremental forming of titanium sheets. Int. J. Adv. Manuf. Technol. 2018, 96, 3311-3319. [CrossRef]

224. Adams, D.; Jeswiet, J. Single point incremental forming of 6061-T6 using electrically assisted forming methods. Proc. Inst. Mech. Eng. B J. Eng. Manuf. 2014, 228, 757-764. [CrossRef] 
225. Bao, W.; Chu, X.; Lin, S.; Gao, J. Experimental investigation on formability and microstructure of AZ31B alloy in electropulse-assisted incremental forming. Mater. Des. 2015, 87, 632-639. [CrossRef]

226. Honarpisheh, M.; Abdolhoseini, M.J.; Amini, S. Experimental and numerical investigation of the hot incremental forming of Ti-6Al-4V sheet using electrical current. Int. J. Adv. Manuf. Technol. 2016, 83, 2027-2037. [CrossRef]

227. Khazaali, H.; Fereshteh-Saniee, F. A comprehensive experimental investigation on the influences of the process variables on warm incremental forming of Ti-6Al-4V titanium alloy using a simple technique. Int. J. Adv. Manuf. Technol. 2016, 87, 2911-2923. [CrossRef]

228. Liu, R.; Lu, B.; Xu, D.; Chen, J.; Chen, F.; Ou, H.; Long, H. Development of novel tools for electricity-assisted incremental sheet forming of titanium alloy. Int. J. Adv. Manuf. Technol. 2016, 85, 1137-1144. [CrossRef]

229. Najafabady, S.A.; Ghaei, A. An experimental study on dimensional accuracy, surface quality, and hardness of Ti-6Al-4 V titanium alloy sheet in hot incremental forming. Int. J. Adv. Manuf. Technol. 2016, 87, 3579-3588. [CrossRef]

230. Li, Z.; Lu, S.; Zhang, T.; Zhang, C.; Mao, Z. 1060 Al electric hot incremental sheet forming process: Analysis of dimensional accuracy and temperature. Trans. Indian Inst. Met. 2018, 71, 961-970. [CrossRef]

231. Li, Z.; Lu, S.; Zhang, T.; Zhang, C.; Mao, Z. Electric assistance hot incremental sheet forming: An integral heating design. Int. J. Adv. Manuf. Technol. 2018, 96, 3209-3215. [CrossRef]

232. Magnus, C.S. Joule heating of the forming zone in incremental sheet metal forming: Part 1. Int. J. Adv. Manuf. Technol. 2017, 91, 1309-1319. [CrossRef]

233. Magnus, C.S. Joule heating of the forming zone in incremental sheet metal forming: Part 2. Int. J. Adv. Manuf. Technol. 2017, 89, 295-309. [CrossRef]

234. Min, J.; Seim, P.; Störkle, D.; Thyssen, L.; Kuhlenkötter, B. Thermal modeling in electricity assisted incremental sheet forming. Int. J. Mater. Form. 2017, 10, 729-739. [CrossRef]

235. Pacheco, P.A.P.; Silveira, M.E. Numerical simulation of electric hot incremental sheet forming of 1050 aluminum with and without preheating. Int. J. Adv. Manuf. Technol. 2017, 94, 3097-3108. [CrossRef]

236. Palumbo, G.; Brandizzi, M. Experimental investigations on the single point incremental forming of a titanium alloy component combining static heating with high tool rotation speed. Mater. Des. 2012, 40, 43-51. [CrossRef]

237. Liu, Z. Heat-assisted incremental sheet forming: A state-of-the-art review. Int. J. Adv. Manuf. Technol. 2018, 98, 2987-3003. [CrossRef]

238. Albakri, M.; Abu-Farha, F.; Khraisheh, M. A new combined experimental-numerical approach to evaluate formability of rate dependent materials. Int. J. Mech. Sci. 2013, 66, 55-66. [CrossRef]

239. Wang, L.; Strangwood, M.; Balint, D.; Lin, J.; Dean, T. Formability and failure mechanisms of AA2024 under hot forming conditions. Mater. Sci. Eng. A 2011, 528, 2648-2656. [CrossRef]

240. Hmida, R.; Thibaud, S.; Gilbin, A.; Richard, F. Influence of the initial grain size in single point incremental forming process for thin sheets metal and microparts: Experimental investigations. Mater. Des. 2013, 45, 155-165. [CrossRef]

241. Ambrogio, G.; Ciancio, C.; Filice, L.; Gagliardi, F. Theoretical model for temperature prediction in Incremental Sheet Forming-Experimental validation. Int. J. Mech. Sci. 2016, 108, 39-48.

242. Bhattacharya, A.; Maneesh, K.; Reddy, N.; Cao, J. Formability and surface finish studies in single point incremental forming. J. Manuf. Sci. Eng. 2011, 133, 061020. [CrossRef]

243. Bagudanch, I.; Garcia-Romeu, M.L.; Centeno, G.; Elías-Zúñiga, A.; Ciurana, J. Forming force and temperature effects on single point incremental forming of polyvinylchloride. J. Mater. Process. Technol. 2015, 219, $221-229$. [CrossRef]

244. Bagudanch, I.; Vives-Mestres, M.; Sabater, M.; Garcia-Romeu, M. Polymer incremental sheet forming process: Temperature analysis using response surface methodology. Mater. Manuf. Process. 2017, 32, 44-53. [CrossRef]

245. Medina-Sanchez, G.; Garcia-Collado, A.; Carou, D.; Dorado-Vicente, R. Force Prediction for Incremental Forming of Polymer Sheets. Materials 2018, 11, 1597. [CrossRef] [PubMed]

246. Clavijo-Chaparro, S.L.; Iturbe-Ek, J.; Lozano-Sánchez, L.M.; Sustaita, A.O.; Elías-Zúñiga, A. Plasticized and reinforced poly(methyl methacrylate) obtained by a dissolution-dispersion process for single point incremental forming: Enhanced formability towards the fabrication of cranial implants. Polym. Test. 2018, 68, 39-45. [CrossRef] 
247. Medina-Sánchez, G.; Torres-Jimenez, E.; Lopez-Garcia, R.; Dorado-Vicente, R.; Cazalla-Moral, R. Temperature influence on Single Point Incremental Forming of PVC parts. Procedia Manuf. 2017, 13, 335-342. [CrossRef]

248. Shim, M.; Park, J. The formability of aluminum sheet in incremental forming. J. Mater. Process. Technol. 2001, 113, 654-658. [CrossRef]

249. Kim, Y.; Park, J. Effect of process parameters on formability in incremental forming of sheet metal. J. Mater. Process. Technol. 2002, 130, 42-46. [CrossRef]

250. Hussain, G.; Gao, L.; Hayat, N.; Cui, Z.; Pang, Y.; Dar, N. Tool and lubrication for negative incremental forming of a commercially pure titanium sheet. J. Mater. Process. Technol. 2008, 203, 193-201. [CrossRef]

251. Lu, B.; Fang, Y.; Xu, D.; Chen, J.; Ou, H.; Moser, N.; Cao, J. Mechanism investigation of friction-related effects in single point incremental forming using a developed oblique roller-ball tool. Int. J. Mach. Tools Manuf. 2014, 85, 14-29. [CrossRef]

252. Jeswiet, J.; Micari, F.; Hirt, G.; Bramley, A.; Duflou, J.; Allwood, J. Asymmetric single point incremental forming of sheet metal. CIRP Ann. 2005, 54, 88-114. [CrossRef]

253. Malhotra, R.; Bhattacharya, A.; Kumar, A.; Reddy, N.; Cao, J. A new methodology for multi-pass single point incremental forming with mixed toolpaths. CIRP Ann. 2011, 60, 323-326. [CrossRef]

254. López, C.; Elías-Zúñiga, A.; Jiménez, I.; Martínez-Romero, O.; Siller, H.R.; Diabb, J.M. Experimental Determination of Residual Stresses Generated by Single Point Incremental Forming of AlSi10Mg Sheets Produced Using SLM Additive Manufacturing Process. Materials 2018, 11, 2542. [CrossRef] [PubMed]

255. Hajavifard, R.; Maqbool, F.; Schmiedt-Kalenborn, A.; Buhl, J.; Bambach, M.; Walther, F. Integrated Forming and Surface Engineering of Disc Springs by Inducing Residual Stresses by Incremental Sheet Forming. Materials 2019, 12, 1646. [CrossRef] [PubMed]

256. Zhang, X.; He, T.; Miwa, H.; Nanbu, T.; Murakami, R.; Liu, S.; Cao, J.; Wang, Q.J. A new approach for analyzing the temperature rise and heat partition at the interface of coated tool tip-sheet incremental forming systems. Int. J. Heat Mass Transf. 2019, 129, 1172-1183. [CrossRef]

257. Araghi, B.T.; Manco, G.L.; Bambach, M.; Hirt, G. Investigation into a new hybrid forming process: Incremental sheet forming combined with stretch forming. CIRP Ann. 2009, 58, 225-228. [CrossRef]

258. Tandon, P.; Sharma, O.N. Experimental investigation into a new hybrid-forming process: Incremental stretch drawing. Proc. Inst. Mech. Eng. Part B J. Eng. Manuf. 2016, 232, 475-486. [CrossRef]

259. Jagtab, R.; Kumar, S. An experimental investigation on thinning and formability in hybrid incremental sheet forming process. Procedia Manuf. 2019, 30, 71-76. [CrossRef]

260. Araghi, B.T.; Göttmann, A.; Bambach, M.; Hirt, G.; Bergweiler, G.; Diettrich, J.; Steiners, M.; Saeed-Akbari, A. Review on the development of a hybrid incremental sheet forming system for small batch sizes and individualized production. Prod. Eng. 2011, 5, 393-404. [CrossRef]

261. Lu, B.; Zhang, H.; Xu, D.K.; Chen, J. A Hybrid Flexible Sheet Forming Approach towards Uniform Thickness Distribution. Procedia CIRP 2014, 18, 244-249. [CrossRef]

262. Allwood, J.; Braun, D.; Music, O. The effect of partially cut-out blanks on geometric accuracy in incremental sheet forming. J. Mater. Proc. Technol. 2010, 210, 1501-1510. [CrossRef]

263. Dong, G.J.; Zhao, C.C.; Cao, M.Y. Flexible-die forming process with solid granule medium on sheet metal. Trans. Nonferrous Met. Soc. China 2013, 23, 2666-2677. [CrossRef]

264. Koç, M.; Billur, E.; Necati, Ö.N. An experimental study on the comparative assessment of hydraulic bulge test analysis methods. Mater. Des. 2011, 32, 272-281. [CrossRef]

265. Yang, X.Y.; Lang, L.H.; Liu, K.N.; Liu, B.S. Mechanics analysis of axisymmetric thin-walled part in warm sheet hydroforming. Chin. J. Aeronaut. 2015, 28, 1546-1554. [CrossRef]

266. Zhou, G.; Wang, Y.N.; Lang, L.H. Accuracy analysis of complex curvature parts based on the rigid-flexible hydroforming. Int. J. Adv. Manuf. Technol. 2018, 99, 247-254. [CrossRef]

267. Woźniak, D.; Głowacki, M.; Hojny, M.; Pieja, T. Application of CAE systems in forming of drawpieces with use rubber-pad forming processes. Arch. Metall. Mater. 2012, 57, 1179-1187. [CrossRef]

268. Belhassen, L.; Koubaa, S.; Wali, M.; Dammak, F. Numerical prediction of springback and ductile damage in rubber-padforming process of aluminum sheet metal. Int. J. Mech. Sci. 2016, 117, 218-226. [CrossRef]

269. Irthiea, I.; Green, G.; Hashim, S.; Kriama, A. Experimental and numerical investigation on micro deep drawing process of stainless steel 304 foil using flexible tools. Int. J. Mach. Tools Manuf. 2014, 76, 21-33. [CrossRef] 
270. Trzepiecinski, T.; Malinowski, T.; Pieja, T. Experimental and numerical analysis of industrial warm forming of stainless steel sheet. J. Manuf. Process. 2017, 30, 532-540. [CrossRef]

271. Chen, L.; Chen, H.; Guo, W.; Chen, G.; Wang, Q. Experimental and simulation studies of springback in rubber forming using aluminium sheet straight flanging process. Mater. Des. 2014, 54, 354-360. [CrossRef]

272. Jin, C.K.; Jeong, M.G.; Kang, C.G. Effect of rubber forming process parameters on micro-patterning of thin metallic plates. Procedia Eng. 2014, 81, 1439-1444. [CrossRef]

273. Liu, Y.; Hua, L.; Lan, J.; Wei, X. Studies of the deformation styles of the rubber-pad forming process used for manufacturing metallic bipolar plates. J. Power Sources 2010, 195, 8177-8184. [CrossRef]

274. Zhang, Q.; Wang, Z.R.; Dean, T.A. The mechanics of multi-point sandwich forming. Int. J. Mach. Tools Manuf. 2008, 48, 1495-1503. [CrossRef]

275. Walczyk, D.F.; Hosford, J.F.; Papazian, J.M. Using reconfigurable tooling and surface heating for incremental forming of composite aircraft parts. J. Manuf. Sci. Eng. 2003, 125, 333-343. [CrossRef]

276. Li, M.Z.; Cai, Z.Y.; Sui, Z.; Yan, Q.G. Multi-point forming technology for sheet metal. J. Mater. Process. Technol. 2002, 129, 333-338. [CrossRef]

277. Chen, J.J.; Li, M.Z.; Liu, W.; Wang, C.T. Sectional multipoint forming technology fir large-size sheet metal. Int. J. Adv. Manuf. Technol. 2005, 25, 935-939. [CrossRef]

278. Abosaf, M.; Essa, K.; Alghawail, A.; Tolipov, A.; Su, S.; Pham, D. Optimisation of multi-point forming process parameters. Int. J. Adv. Manuf. Technol. 2017, 92, 1849-1859. [CrossRef]

279. Nakajima, N. A newly developed technique to fabricate complicated dies and electrodes with wires. J. Jpn. Soc. Mech. Eng. 1969, 72, 498-506. [CrossRef]

280. Paunoiu, V.; Teodor, V.; Maier, C.; Baroiu, N.; Bercu, G. Study ofthe tool geometry in reconfigurable multipoint forming. Ann. Dunărea de Jos Univ. Galaţi 2011, 11, 139-144.

281. Sairajan, K.K.; Aglietti, G.S.; Mani, K.M. A review of multifunctional structure technology for aerospace applications. Acta Astronaut. 2016, 120, 30-42. [CrossRef]

282. Sun, G.Y.; Huo, X.T.; Chen, D.D.; Li, Q. Experimental and numerical study on honey-comb sandwich panels under bending and in-panel compression. Mater. Des. 2017, 133, 154-168. [CrossRef]

283. Carradò, A.; Faerber, J.; Niemeyer, S.; Ziegmann, G.; Palkowski, H. Metal/polymer/metalhybrid systems: Towards potential formability applications. Compos. Struct. 2011, 93, 715-721. [CrossRef]

284. Besse, C.C.; Mohr, D. Plasticity of formable all-metal sandwich sheets: Virtual experiments and constitutive modeling. Int. J. Solids Struct. 2012, 49, 2863-2880. [CrossRef]

285. Cai, Z.Y.; Zhang, X.; Liang, X.B. Multi-point forming of sandwich panels with egg-box-like cores andfailure behaviors in forming process: Analytical models, numerical and experimental investigations. Mater. Des. 2018, 160, 1029-1041. [CrossRef]

286. Liang, X.B.; Cai, Z.Y.; Zhang, X. Forming characteristics analysis and springback predictionof bi-directional trapezoidal sandwich panels in the multi-point bend-forming. Int. J. Adv. Manuf. Technol. 2018, 98, 1709-1720. [CrossRef]

287. Zhang, S.H.; Chen, S.F.; Ma, Y.; Song, H.W.; Cheng, M. Developments of new sheet metal forming technology and theory in China. Acta Metall. Sin. 2015, 28, 1452-1470. [CrossRef]

288. Chen, H.; Güner, A.; Khalifa, N.B.; Tekkaya, A.E. Granular media-based tube press hardening. J. Mater. Process. Tech. 2016, 228, 145-159. [CrossRef]

289. Dong, G.J.; Zhao, C.C.; Cao, M.Y. Process of back pressure deep drawing with solid granule medium on sheet metal. J. Cent. South. Univ. 2014, 21, 2617-2626. [CrossRef]

290. Psyk, V.; Risch, D.; Kinsey, B.L.; Tekkaya, A.E.; Kleiner, M. Electromagnetic forming-A review. J. Mater. Process. Technol. 2011, 211, 787-829. [CrossRef]

291. Kim, D.; Park, H.I.; Lee, J.; Kim, J.H.; Lee, M.-G.; Lee, Y. Experimental study on forming behavior of high-strength steel sheets under electromagnetic pressure. Proc. Inst. Mech. Eng. Part B J. Eng. Manuf. 2015, 229, 670-681. [CrossRef]

292. Long, A.; Wan, M.; Wang, W.; Wu, X.; Cui, X.; Ma, B. Forming methodology and mechanism of a novel sheet metal forming technology-electromagnetic superposed forming(EMSF). Int. J. Solids Struct. 2018, 151, 165-180. [CrossRef]

293. Lai, Z.; Cao, Q.; Han, X.; Huang, Y.; Deng, F.; Chen, Q.; Li, L. Investigation on plastic deformation behavior of sheet workpiece during radial Lorentz force augmented deep drawing process. J. Mater. Process. Technol. 2017, 245, 193-206. [CrossRef] 
294. Paese, E.; Geier, M.; Homrich, R.P.; Rosa, P.; Rossi, R. Sheet metal electromagnetic forming using a flat spiral coil: Experiments, modeling, and validation. J. Mater. Process. Technol. 2019, 263, 408-422. [CrossRef]

295. Thibaudeau, E.; Kinsey, B.L. Analytical design and experimental validation of uniform pressure actuator for electromagnetic forming and welding. J. Mater. Process. Technol. 2015, 215, 251-263. [CrossRef]

296. Psyk, V.; Kurka, P.; Kimme, S.; Werner, M.; Landgrebe, D.; Ebert, A.; Schwarzendahl, M. Structuring by electromagnetic forming and by forming with an elastomer punch as a tool for component optimisation regarding mechanical stiffness and acoustic performance. Manuf. Rev. 2015, 2, 23. [CrossRef]

297. Mamalis, A.G.; Manolakos, D.E.; Kladas, A.G.; Koumoutsos, A.K.; Ovchinnikov, S.G. Electromagnetic forming of aluminum alloy sheet using a grooved die: Numerical modelling. Phys. Met. Metall. 2006, 102, 590-593. [CrossRef]

298. Golovashchenko, S.F. Material formability and coil design in electromagnetic forming. J. Mater. Eng. Perform. 2007, 16, 314-320. [CrossRef]

299. Balanethiram, V.S.; Hu, X.; Altynova, M.; Daehn, G.S. Hyperplasticity: Enhanced formability at high rates. J. Mater. Process. Technol. 1994, 45, 595-600. [CrossRef]

300. Cui, X.; Zhang, Z.; Yu, H.; Xiao, X.; Cheng, Y. Springback Calibration of a U-Shaped Electromagnetic Impulse Forming Process. Metals 2019, 9, 603. [CrossRef]

301. Xiong, W.R.; Wang, W.P.; Wan, M.; Li, X.J. Geometric issues in V-bending electromagnetic forming process of 2024-T3 aluminum alloy. J. Manuf. Process. 2015, 19, 171-182. [CrossRef]

302. Yu, H.; Chen, J.; Liu, W.; Yin, H.; Li, C. Electromagnetic forming of aluminum circular tubes into square tubes: Experiment and numerical simulation. J. Manuf. Process. 2018, 31, 613-623. [CrossRef]

303. Su, H.; Huang, L.; Li, J.; Ma, F.; Huang, P.; Feng, F. Two-step electromagnetic forming: A new forming approach to local features of large-size sheet metal parts. Int. J. Mach. Tools Manuf. 2018, 124, 99-116. [CrossRef]

304. Kamal, M.; Shang, J.; Cheng, V.; Hatkevich, S.; Daehn, G.S. Agile manufacturing of a micro-embossed case by a two-step electromagnetic forming process. J. Mater. Process. Technol. 2007, 190, 41-50. [CrossRef]

305. Imbert, J.; Worswick, M. Electromagnetic reduction of a pre-formed radius on AA 5754 sheet. J. Mater. Process. Technol. 2011, 211, 896-908. [CrossRef]

306. Li, J.; Qiu, W.; Huang, L.; Su, H.; Tao, H.; Li, P. Gradient electromagnetic forming (GEMF): A new forming approach for variable-diameter tubes by use of sectional coil. Int. J. Mach. Tools Manuf. 2018, 135, 65-77. [CrossRef]

307. Centeno, G.; Martínez-Donaire, A.J.; Bagudanch, I.; Morales-Palma, D.; Garcia-Romeu, M.L.; Vallellano, C. Revisiting Formability and Failure of AISI304 Sheets in SPIF: Experimental Approach and Numerical Validation. Metals 2017, 7,531. [CrossRef]

308. Centeno, G.; Martínez-Donaire, A.J.; Morales-Palma, D.; Vallellano, C.; Martins, P.A.F. Novel experimental techniques for the determination of the forming limits at necking and fracture. In Materials Forming and Machining; Davim, P., Ed.; Woodhead Publishing: Cambridge, UK, 2016; pp. 1-24.

309. Cui, X.H.; Mo, J.H.; Li, J.J.; Zhao, J.; Zhu, Y.; Huang, L.; Li, W.Z.; Zhong, K. Electromagnetic incremental forming (EMIF): A novel aluminum alloy sheet and tube forming technology. J. Mater. Process. Technol. 2014, 214, 409-427. [CrossRef]

310. Lai, Z.; Cao, Q.; Han, X.; Liu, N.; Li, X.; Huang, Y.; Chen, M.; Cai, H.; Wang, G.; Liu, L.; et al. A comprehensive electromagnetic forming approach for large sheet metal forming. Procedia Eng. 2017, 207, 54-59. [CrossRef]

311. Tan, J.; Zhan, M.; Gao, P.; Li, H. Electromagnetic forming rules of a stiffened panel with grid ribs. Metals 2017, 7, 559. [CrossRef]

312. Cao, T.; Lu, B.; Ou, H.; Long, H.; Chen, J. Investigation on a new hole-flanging approach by incremental sheet forming through a featured tool. Int. J. Mach. Tools Manuf. 2016, 110, 1-17. [CrossRef]

313. Li, C.; Liu, D.; Yu, H.; Ji, Z. Research on formability of 5052 aluminum alloy sheet in a quasi-static-dynamic tensile process. Int. J. Mach. Tools Manuf. 2009, 49, 117-124. [CrossRef]

314. Kacem, A.; Krichen, A.; Manach, P.Y.; Thuillier, S.; Yoon, J.W. Failure prediction in the hole-flanging process of aluminium alloys. Eng. Fract. Mech. 2013, 99, 251-265. [CrossRef]

315. Krichen, A.; Kacem, A.; Hbaieb, M. Blank-holding effect on the hole-flanging process of sheet aluminum alloy. J. Mater. Process. Technol. 2011, 211, 619-626. [CrossRef]

316. Su, H.; Huang, L.; Li, J.; Ma, F.; Ma, H.; Huang, P.; Zhu, H.; Feng, F. Inhomogeneous deformation behaviors of oblique hole-flanging parts during electromagnetic forming. J. Manuf. Process. 2020, 52, 1-11. [CrossRef] 
317. Feng, F.; Li, J.; Yuan, P.; Zhang, Q.; Huang, P.; Su, H.; Chen, R. Application of a GTN Damage Model Predicting the Fracture of 5052-O Aluminum Alloy High-Speed Electromagnetic Impaction. Metals 2018, 8, 761. [CrossRef]

318. Gillard, A.J.; Golovashchenko, S.F.; Mamutov, A.V. Effect of quasi-static prestrain on the formability of dual phase steels in electrohydraulic forming. J. Manuf. Process. 2013, 15, 201-218. [CrossRef]

319. Mamutov, A.V.; Golovashchenko, S.F.; Mamutov, V.S.; Bonnen, J.J.F. Modeling of electrohydraulic forming of sheet metal parts. J. Mater. Process. Technol. 2015, 219, 84-100. [CrossRef]

320. Golovashchenko, S.F.; Gillard, A.J.; Mamutov, A.V. Formability of dual phase steels in electrohydraulic forming. J. Mater. Process. Technol. 2013, 213, 1191-1212. [CrossRef]

321. Golovashchenko, S.F.; Mamutov, A.V.; Bonnen, J.J.F.; Gillard, A.J. Electrohydraulic forming of sheet metal parts. In Proceedings of the International Conference on the Technology of Plasticity, Aachen, Germany, 25-30 September 2011; pp. 1170-1175.

322. Golovashchenko, S.F.; Bessonov, N.M.; Ilinich, A.M. Two-step method of forming complex shapes from sheet metal. J. Mater. Process. Technol. 2011, 211, 875-885. [CrossRef]

323. Samei, J.; Green, D.E.; Golovashchenko, S.; Hassannejadasl, A. Quantitative microstructural analysis of formability enhancement in dual phase steels subject to electrohydraulic forming. J. Mater. Eng. Perform. 2013, 22, 2080-2088. [CrossRef]

324. Maris, C.; Hassannejadasl, A.; Green, D.E.; Cheng, J.; Golovashchenko, S.F.; Gillard, A.J.; Liang, Y. Comparison of quasi-static and electrohydraulic free forming limits for DP600 and AA5182 sheets. J. Mater. Process. Technol. 2016, 235, 206-219. [CrossRef]

325. Zia, M.; Fazli, A.; Soltananpour, M. Warm electrohydraulic forming: A novel high speed forming process. Procedia Eng. 2017, 207, 323-328. [CrossRef]

326. Ahmed, K.I.; Gadala, M.S.; El-Sebaie, M.G. Deep spinning of sheet metals. Int. J. Mach. Tools Manuf. 2015, 97, 72-85. [CrossRef]

327. Xia, Q.; Shima, S.; Kotera, H.; Yasuhuku, D. A study of the one-path deep drawing spinning of cups. J. Mater. Process. Technol. 2005, 159, 397-400. [CrossRef]

328. Abd-Alrazzaq, M.; Ahmed, M.; Younes, M. Experimental Investigation on the Geometrical Accuracy of the CNC Multi-Pass Sheet Metal Spinning Process. J. Manuf. Mater. Process. 2018, 2, 59. [CrossRef]

329. Liu, R.; Yu, Z.; Zhao, Y.; Evsyukov, S.A. Formability of Flange Constraint Spinning for Aluminum Cup Part. J. Shanghai Jiaotong Univ. Sci. 2019, 53, 105-110.

330. Xia, Q.; Xiao, G.; Long, H.; Cheng, X.; Sheng, X. A review of process advancement of novel metal spinning. Int. J. Mach. Tools Manuf. 2014, 85, 100-121. [CrossRef]

331. Mori, K.I.; Ishiguro, M.; Isomura, Y. Hot shear spinning of cast aluminium alloy parts. J. Mater. Process. Technol. 2009, 209, 3621-3627. [CrossRef]

332. Wong, C.C.; Dean, T.A.; Lin, J. A review of spinning, shear forming and flow forming processes. Int. J. Mach. Tools Manuf. 2003, 43, 1419-1435. [CrossRef]

333. Music, O.; Allwood, J.M.; Kawai, K. A review of the mechanics of metal spinning. J. Mater. Process. Technol. 2010, 210, 3-23. [CrossRef]

334. Żaba, K.; Nowosielski, M.; Puchlerska, S.; Kwiatkowski, M.; Kita, P.; Głodzik, M.; Korfanty, K.; Pociecha, D.; Pieja, T. Investigation of the mechanical properties and microstructure of nickel superalloys processed in shear forming. Arch. Metall. Mater. 2015, 60, 2637-2644. [CrossRef]

335. Plewiński, A.; Drenger, T. Spinning and flow forming hard-to-deform metal alloys. Arch. Civ. Mech. Eng. 2009, 9, 101-109. [CrossRef]

336. Chang, S.C.; Huang, C.A.; Yu, S.Y.; Chang, Y.; Han, W.C.; Shieh, T.S.; Chung, H.C.; Yao, H.T.; Shyu, G.D.; Hou, H.Y.; et al. Tube spinnability of AA2024 and 7075 aluminum. J. Mater. Process. Technol. 1998, 80-81, 676-682. [CrossRef]

337. Żaba, K.; Puchlerska, S.; Kwiatkowski, M.; Nowosielski, M.; Głodzik, M.; Tokarski, T.; Seibt, P. Comparative analysis of properties and microstructure of the plastically deformed alloy Inconel@718 manufactured by plastic working and direct metal laser sintering. Arch. Metall. Mater. 2016, 61, 143-148. [CrossRef]

338. Polyblank, J.A.; Allwood, J.M. Parametric toolpath design in metal spinning. CIRP Ann. 2015, 64, 301-304. [CrossRef]

339. Shimizu, I. Asymmetric forming of aluminium sheets by synchronous spinning. J. Mater. Process. Technol. 2010, 210, 585-592. [CrossRef] 
340. Cheng, X.Q.; Xia, Q.; Lai, Z.Y. Investigation on stress and strain distributions of hollow-part with triangular cross-section by spinning. Int. J. Mater. Prod. Technol. 2013, 47, 162-174. [CrossRef]

341. Xia, Q.; Lai, Z.Y.; Long, H.; Cheng, X.Q. A study of the spinning force of hollow parts with triangular cross sections. Int. J. Adv. Manuf. Technol. 2013, 68, 2461-2470. [CrossRef]

342. Sugita, Y.; Arai, H. Formability in synchronous multipass spinning using simple pass set. J. Mater. Process. Technol. 2015, 217, 336-344. [CrossRef]

343. Jia, Z.; Xu, Q.; Han, Z.; Peng, W.F. Precision forming of the straight edge of square section by die-less spinning. J. Manuf. Sci. Eng. 2015, 138, 011006. [CrossRef]

344. Russo, I.M.; Loukaides, E.G. Toolpath generation for asymmetric mandrel-free spinning. Procedia Eng. 2017, 207, 1707-1712. [CrossRef]

345. Polyblank, J.A.; Allwood, J.M.; Duncan, S.R. Closed-loop control of product properties in metal forming: A review and prospectus. J. Mater. Process. Technol. 2014, 214, 2333-2348. [CrossRef]

346. Wang, L.; Long, H. Roller path design by tool compensation in multi-pass conventional spinning. Mater. Des. 2013, 46, 645-653. [CrossRef]

347. Watson, M.; Long, H. Wrinkling failure mechanics in metal spinning. Procedia Eng. 2014, 81, 2391-2396. [CrossRef]

348. Wang, L.; Long, H.; Ashley, D.; Roberts, M.; White, P. Effects of the roller feed ratio on wrinkling failure in conventional spinning of a cylindrical cup. Proc. Inst. Mech. Eng. Part B J. Eng. Manuf. 2011, 225, 1991-2006. [CrossRef]

349. Watson, M.; Long, H.; Lu, B. Investigation of wrinkling failure mechanics in metal spinning by Box-Behnken design of experiments using finite element method. Int. J. Adv. Manuf. Technol. 2015, 78, 981-995. [CrossRef]

350. El-Khabeery, M.M.; Fattouh, M.; El-Sheikh, M.N.; Hamed, O.A. On the conventional simple spinning of cylindrical aluminium cups. Int. J. Mach. Tools Manuf. 1991, 31, 203-219. [CrossRef]

351. Russo, I.M.; Cleaver, C.J.; Allwood, J.M. Haptic metal spinning. Procedia Manuf. 2019, 29, 129-136. [CrossRef]

352. Xia, P. Haptics for Product Design and Manufacturing Simulation. IEEE Trans. Haptics 2016, 9, $358-375$. [CrossRef] [PubMed]

353. Russo, I.M.; Cleaver, C.J.; Allwood, J.M.; Loukaides, E.G. The influence of part asymmetry on the achievable forming height in multi-pass spinning. J. Mater. Process. Technol. 2020, 275, 116350. [CrossRef]

354. Music, O.; Allwood, J.M. Flexible asymmetric spinning. CIRP Ann. 2011, 60, 319-322. [CrossRef]

355. Arai, H. Robotic metal spinning-Forming non-axisymmetric products using force control. J. Robot. Soc. Jpn. 2006, 24, 140-145. (In Japanese) [CrossRef]

356. Lossen, B.; Homberg, W. Friction-spinning - Interesting Approach to Manufacture of Complex Sheet Metal Parts and Tubes. Procedia Eng. 2014, 81, 2379-2384. [CrossRef]

357. Brummer, C.; Eck, S.; Marsoner, S.; Arntz, K.; Klocke, F. Laser-assisted metal spinning for an efficient and flexible processing of challenging materials. IOP Conf. Sci. Mater. Sci. Eng. 2016, 119, 012022. [CrossRef]

358. Sim, M.S.; Lee, C.M. A study on the laser preheating effect of Inconel 718 specimen with rotated angle with respect to 2-axis. Int. J. Precis. Eng. Manuf. 2014, 15, 189-192. [CrossRef]

359. Li, Y.H.; Fan, T.; Zhang, N. Research on Ball Spinning Forming of Superalloy Inconel 718 Thin-Walled Tube. Adv. Mater. Res. 2011, 189-193, 2742-2745. [CrossRef]

360. Yoshihara, S.; Donald, B.M.; Hasegawa, T.; Kawahara, M.; Yamamoto, H. Design improvement of spin forming of magnesium alloy tubes using finite element. J. Mater. Proc. Technol. 2004, 153-154, 816-820. [CrossRef]

361. Yang, H.; Huang, L.; Zhan, M. Coupled thermo-mechanical FE smulation of the hot splitting spinning process of magnesium alloy AZ31. Comput. Mater. Sci. 2010, 47, 857-866. [CrossRef]

362. Jin, K.; Wang, J.; Guo, X.; Dombelsky, J.; Wang, H.; Jin, X.; Ding, R. Experimental analysis of electro-assisted warm spin forming of commercial pure titanium components. Int. J. Adv. Manuf. Technol. 2019, 102, $293-304$. [CrossRef]

363. Jiang, S.S.; Tang, Z.J.; Du, H.; Chen, J.; Zhang, J.T. Research progress of current assisted forming process for titanium alloys. Precis. Form. Eng. 2017, 9, 7-13.

364. Magargee, J.; Morestin, F.; Cao, J. Characterization of flow stress for commercially pure titanium subjected to electrically assisted deformation. J. Eng. Mater. Technol. 2013, 135, 041003. [CrossRef]

365. Nguyen-Tran, H.D.; Oh, H.S.; Hong, S.T.; Han, H.N.; Cao, J.; Ahn, S.H.; Chun, D.M. A review of electrically-assisted manufacturing. Int. J. Precis. Eng. Manuf.-Green Technol. 2015, 2, 365-376. [CrossRef] 
366. Homberg, W.; Hornjak, D.; Beerwald, C. Manufacturing of complex functional graded workpieceswith the frictio-spinning process. Int. J. Mater. Form. 2010, 3, 843-946. [CrossRef]

367. Zhan, M.; Yang, H.; Guo, J.; Wang, X.X. Review on hot spinning for difficult-to-deform lightweight metals. Trans. Nonferrous Met. Soc. China 2015, 25, 1732-1743. [CrossRef]

368. Childerhouse, T.; Long, H. Processing maps for wrinkle free and quality enhanced parts by shear spinning. Procedia Manuf. 2019, 29, 137-144. [CrossRef]

369. Hatori, S.; Sekiguchi, A.; Özerc, A. Conceptual design of multipurpose forming machine and experiments on force-controlled shear spinning of truncated cone. Procedia Manuf. 2018, 15, 1255-1262. [CrossRef]

370. Han, Z.R.; Fan, Z.J.; Xiao, Y.; Jia, Z. The constant temperature control system of multi-pass and die-less shear spinning by flame heating. Int. J. Adv. Manuf. Technol. 2018, 97, 2439-2446. [CrossRef]

371. Lee, H.S.; Song, Y.B.; Hong, S.S. Shear Spinning of Ti-6Al-4V Alloy at Hot Working Temperature. Trans. Mater. Process. 2011, 20, 432-438. [CrossRef]

372. Niklasson, F. Shear Spinning of Nickelbased Super-Alloy 718. In The Minerals, Metals E Materials Series; Ott, E., Liu, X., Andersson, J., Bi, Z., Bockenstedt, K., Dempster, I., Groh, J., Heck, K., Jablonski, P., Kaplan, M., et al., Eds.; Springer: Cham, Switzerland, 2018; pp. 769-778.

373. Prakash, R.; Singhal, R.P. Shear spinning technology for manufacture of long thin wall tubes of small bore. J. Mater. Process. Technol. 1995, 54, 186-192. [CrossRef]

374. Sekiguchi, A.; Arai, H. Control of wall thickness distribution by oblique shear spinning methods. J. Mater. Process. Technol. 2012, 212, 786-793. [CrossRef]

375. Suzuki, N.; Tokuhiro, S.; Takeuchi, O. Double cylinder forming by die-less shear spinning for air intake lip skin for aero jest engine nacelle. Procedia Manuf. 2018, 15, 1270-1277. [CrossRef]

376. Jia, Z.; Li, D.C.; Han, Z.R.; Xiao, Y. Mechanics of double-sheet die-less shear spinning: A novel potential method for wall thickness control in spinning process. J. Braz. Soc. Mech. Sci. Eng. 2019, 41, 497. [CrossRef]

377. Bylya, O.I.; Khismatullin, T.; Blackwell, P.; Vasin, R.A. The effect of elasto-plastic properties of materials on their formability by flow forming. J. Mater. Process. Technol. 2018, 252, 34-44. [CrossRef]

378. Sivanandini, M.; Dhami, S.S.; Pabla, B.S. Flow forming of tubes-A review. Int. J. Sci. Eng. Res. 2012, 3, 1-11.

379. Zhao, M.J.; Wu, Z.L.; Chen, Z.R.; Huang, X.B. Analysis of flow control forming of magnesium alloy wheel. IOP Conf. Ser. Mater. Sci. Eng. 2017, 170, 012006. [CrossRef]

380. Wang, X.; Gao, P.; Zhan, M.; Yang, K.; Dong, Y.; Li, Y. Development of microstructural inhomogeneity in multi-pass flow forming of TA15 alloy cylindrical parts. Chin. J. Aeronaut. 2019. [CrossRef]

381. Singh, A.K.; Nrasimhan, K.; Singh, R. Finite element modeling of backward flow forming of Ti6Al4V alloy. Mater. Today Proc. 2018, 5, 24963-24970. [CrossRef] 